


Previous page: Jurassic sediments exposed in a clay-pit at Bagå on Bornholm, Denmark - see Michelsen et al. (2003, this volume). Photo: Peter K. Warna-Moors. 


\title{
Jurassic lithostratigraphy and stratigraphic development onshore and offshore Denmark
}

\author{
Olaf Michelsen, Lars H. Nielsen, Peter N. Johannessen, Jan Andsbjerg and Finn Surlyk
}

A complete updated and revised lithostratigraphic scheme for the Jurassic succession of the onshore and offshore Danish areas is presented together with an overview of the geological evolution. The lithostratigraphies of Bornholm, the Danish Basin and the Danish Central Graben are described in ascending order, and a number of new units are defined. On Bornholm, the Lower-Middle Jurassic coal-bearing clays and sands that overlie the Lower Pliensbachian Hasle Formation are referred to the new Sorthat Formation (Lower Jurassic) and the revised Bagå Formation (Middle Jurassic). In the southern Danish Central Graben, the Middle Jurassic succession formerly referred to the Lower Graben Sand Formation is now included in the revised Bryne Formation. The Lulu Formation is erected to include the uppermost part of the Middle Jurassic succession, previously referred to the Bryne Formation in the northern Danish Central Graben. The Upper Jurassic Heno Formation is subdivided into two new members, the Gert Member (lower) and the Ravn Member (upper). The organic-rich part of the upper Farsund Formation, the former informal 'hot unit', is established formally as the Bo Member.

Dominantly shallow marine and paralic deposition in the Late Triassic was succeeded by widespread deposition of offshore marine clays in the Early Jurassic. On Bornholm, coastal and paralic sedimentation prevailed. During maximum transgression in the Early Toarcian, sedimentation of organic-rich offshore clays took place in the Danish area. This depositional phase was terminated by a regional erosional event in early Middle Jurassic time, caused by uplift of the central North Sea area, including the Ringkøbing-Fyn High. In the Sorgenfrei-Tornquist Zone to the east, where slow subsidence continued, marine sandy sediments were deposited in response to the uplift. Uplift of the central North Sea area was followed by fault-controlled subsidence accompanied by fluvial and floodplain deposition during Middle Jurassic time. On Bornholm, deposition of lacustrine muds, fluvial sands and peats dominated. The late Middle Jurassic saw a gradual shift to shallow marine deposition in the Danish Central Graben, the Danish Basin and Skåne, southern Sweden. During the Late Jurassic, open marine shelf conditions prevailed with deposition of clay-dominated sediments while shallow marine sands were deposited on platform areas. The Central Graben received sand by means of sediment gravity flows. The clay sediments in the Central Graben became increasingly rich in organic matter at the Jurassic-Cretaceous transition, whilst shallow marine coarse-grained deposits prograded basinwards in the SorgenfreiTornquist Zone.

Keywords: Denmark, Danish Central Graben, Danish Basin, Sorgenfrei-Tornquist Zone, Bornholm, Jurassic, lithostratigraphy, basin development

O.M., Geological Institute, University of Aarbus, C.F. Møllers Allé, DK-8000 Årbus C, Denmark.

L.H.N., P.N.J. \& J.A., Geological Survey of Denmark and Greenland, Geocenter Copenhagen, Øster Voldgade 10, DK-1350 Copenhagen K, Denmark. E-mail: Ihn@geus.dk

F.S., Geological Institute, University of Copenhagen, Geocenter Copenhagen, Øster Voldgade 10, DK-1350 Copenhagen K, Denmark. 


\section{Contents}

Regional setting Lithostratigraphy Bornholm

Rønne Formation

Hasle Formation

Sorthat Formation

Bagå Formation

Danish Basin

Gassum Formation

Fjerritslev Formation

Haldager Sand Formation

Flyvbjerg Formation

Børglum Formation

Frederikshavn Formation

Danish Central Graben

Fjerritslev Formation

Bryne Formation

Lulu Formation

Lola Formation

Heno Formation

Gert Member

Ravn Member

Farsund Formation

Bo Member

Poul Formation

Stratigraphic evolution

Early Jurassic marine deposition

Middle Jurassic uplift

Middle Jurassic fluvial and paralic deposition

Late Jurassic marine deepening

Late Jurassic graben development and sedimentation

References
Middle Graben Formation

Acknowledgements

Jurassic deposits extend throughout most of the Danish area, from the island of Bornholm in the Baltic Sea in the east to the central part of the North Sea in the west (Fig. 1). They can be studied at outcrop on Bornholm and Skåne (southern Sweden), whereas they are only known from subsurface data over the remainder of the area.

The Jurassic of Bornholm has been studied since the 19th century; the early literature includes Forchhammer (1837), Jespersen (1866, 1869), Bartholin (1892, 1894), Grönwall (1899), Hjort (1899), Møller (1902, 1903), Malling \& Grönwall (1909), Malling (1911, 1914, 1920) and Höhne (1933). The stratigraphy and structural evolution was studied by Gry (1969), and the sedimentary evolution of the Jurassic successions was discussed by Sellwood (1972), Rolle et al. (1979) and Gravesen et al. (1982); the last authors also erected the first formal lithostratigraphic scheme. Palynological studies have been undertaken by Hoelstad (1985), Koppelhus (1991), Koppelhus \& Batten (1992), Batten et al. (1994) and Koppelhus \& Nielsen (1994). Surlyk \& Noe-Nygaard (1986) interpreted the depositional environments of the Pliensbachian Hasle Formation, and the rich ammonite fauna is described by Donovan \& Surlyk (2003, this volume). Surlyk et al. (1995) provided a detailed sequence stratigraphic interpretation of the Hettangian- Sinemurian Sose Bugt Member (Rønne Formation). Koppelhus \& Nielsen (1994) and Petersen \& Nielsen (1995) interpreted the depositional environments of the Upper Pliensbachian - Bathonian Sorthat and Bagå Formations. The coal beds, burial depths and amount of uplift based on coal maturation were studied by Petersen (1993) and Petersen et al. (2003a, b, this volume).

Jurassic sediments in the subsurface are known from a large number of deep wells drilled for hydrocarbon 
and geothermal exploration with supplementary information from seismic surveys. The presence of Jurassic rocks from the subsurface of onshore Denmark was described for the first time by Nørvang (1946) from a borehole situated in northern Jylland near the village of Vejrum. The Vinding-1 well, drilled in 1947, was the first deep onshore well to penetrate the Jurassic. Gregersen \& Sorgenfrei (1951) presented a stratigraphic review of two well sections, Gassum-1 and Vinding-1. A lithological and stratigraphical summary of the Jurassic in a large number of wells was given by Sorgenfrei \& Buch (1964). A lithostratigraphic subdivision of the entire Jurassic succession was undertaken by Larsen (1966), and later refined and partly revised by Bertelsen (1978) and Michelsen (1978a, 1989a). Larsen et al. (1968) described Jurassic strata encountered in wells drilled in the strait between Denmark and Sweden (Øresund); Petersen (1994) studied the genesis of the coals from these wells. Several biostratigraphic studies have been published including those of Nørvang (1957) who examined the Early Jurassic foraminiferal faunas, Michelsen (1975) who established a zonation of the Lower Jurassic based on the ostracod faunas, Dybkjær $(1988,1991)$ and Poulsen $(1992,1994,1996)$ who established a palynological zonation of the Jurassic in the Danish Basin. The depositional environments and bivalve assemblages of the Lower Jurassic Fjerritslev Formation were interpreted by Pedersen $(1985,1986)$. Koch (1983) discussed the depositional environments of the Middle-Upper Jurassic sandstone reservoirs, Thomsen et al. (1987) described the hydrocarbon plays, and Nielsen (1995, 2003, this volume) has described the Upper Triassic Jurassic depositional sequences and the development of the Danish Basin and Fennoscandian Border Zone.

In the Danish North Sea sector, the Jurassic was first penetrated by the A-2 well, drilled in 1967, and Sorgenfrei (1969) indicated the presence of Jurassic marine offshore deposits in the North Sea. The first lithological and stratigraphic summaries of drilled Jurassic successions were presented by Rasmussen $(1974,1978)$. A regional description and a preliminary lithostratigraphic subdivision of the Jurassic succession in the Central Graben were presented by Koch et al. (1982). The lithostratigraphic subdivision defined in the Danish onshore well sections also applies to the easternmost North Sea wells located in the Norwegian-Danish Basin (Michelsen 1978a). A lithostratigraphic scheme for the deposits in the Central Graben was established by Jensen et al. (1986), and Jurassic basin development was discussed by Michelsen et al. (1987). The depositional environments of the Middle Jurassic Bryne and Lulu Formations and the Upper Jurassic Heno Formation were interpreted by Johannessen (1995, 1997, 2003, this volume), Johannessen et al. (1996), Petersen \& Andsbjerg (1996) Andsbjerg (1997, 2003, this volume) and Andsbjerg \& Dybkjær (2003, this volume). Biostratigraphic data from the offshore well sections were presented by Rasmussen (1974, 1978). The Early Jurassic ostracod faunas of the O-1 well were described by Michelsen (1978b), Hoelstad (1986a) studied the palynology of the Middle Jurassic in the U-1 well, and Poulsen $(1986,1991)$ presented a dinoflagellate cyst biostratigraphy of the Middle and Upper Jurassic in two wells from the Central Graben. Dybkjær (1998) and Andsbjerg \& Dybkjær (2003, this volume) presented palynological data from the Middle and Upper Jurassic. The hydrocarbon plays were described by Damtoft et al. (1992); further details on source rocks were provided by Petersen et al. (1996, 1998, 2000), Petersen \& Rosenberg (1998) and Ineson et al. (2003, this volume).

The primary aim of the present paper is to present a complete and updated version of the lithostratigraphic scheme of the entire Danish onshore and offshore area (Fig. 2). In addition, an account is given of the stratigraphic development during the Jurassic Period in the Danish part of the North Sea Basin including the Danish Basin. Biostratigraphic and sequence stratigraphic aspects are dealt with in other papers in this volume and will be referred to where relevant. A summary of the distribution and thickness of the lithostratigraphic units penetrated in well sections can be found in Nielsen \& Japsen (1991).

\section{Regional setting}

The Danish area belongs to the eastern part of the North Sea Basin, which comprises a number of faultbounded basins separated by structural highs (Figs 1, 3). The Danish Jurassic deposits represent a wide range of environments, from dominantly paralic and coastal in the east to deep marine in the west. Differential movements of individual structural features have controlled the distribution of Jurassic deposits. The most important structural features are therefore described briefly below.

The North Sea Basin is separated from the Fennoscandian Shield to the east by the strongly block-faulted Fennoscandian Border Zone (Sorgenfrei \& Buch 1964; Baartman \& Christensen 1975). The zone runs from northernmost Jylland, south-eastwards through Skåne to the island of Bornholm in the Baltic Sea. It comprises 

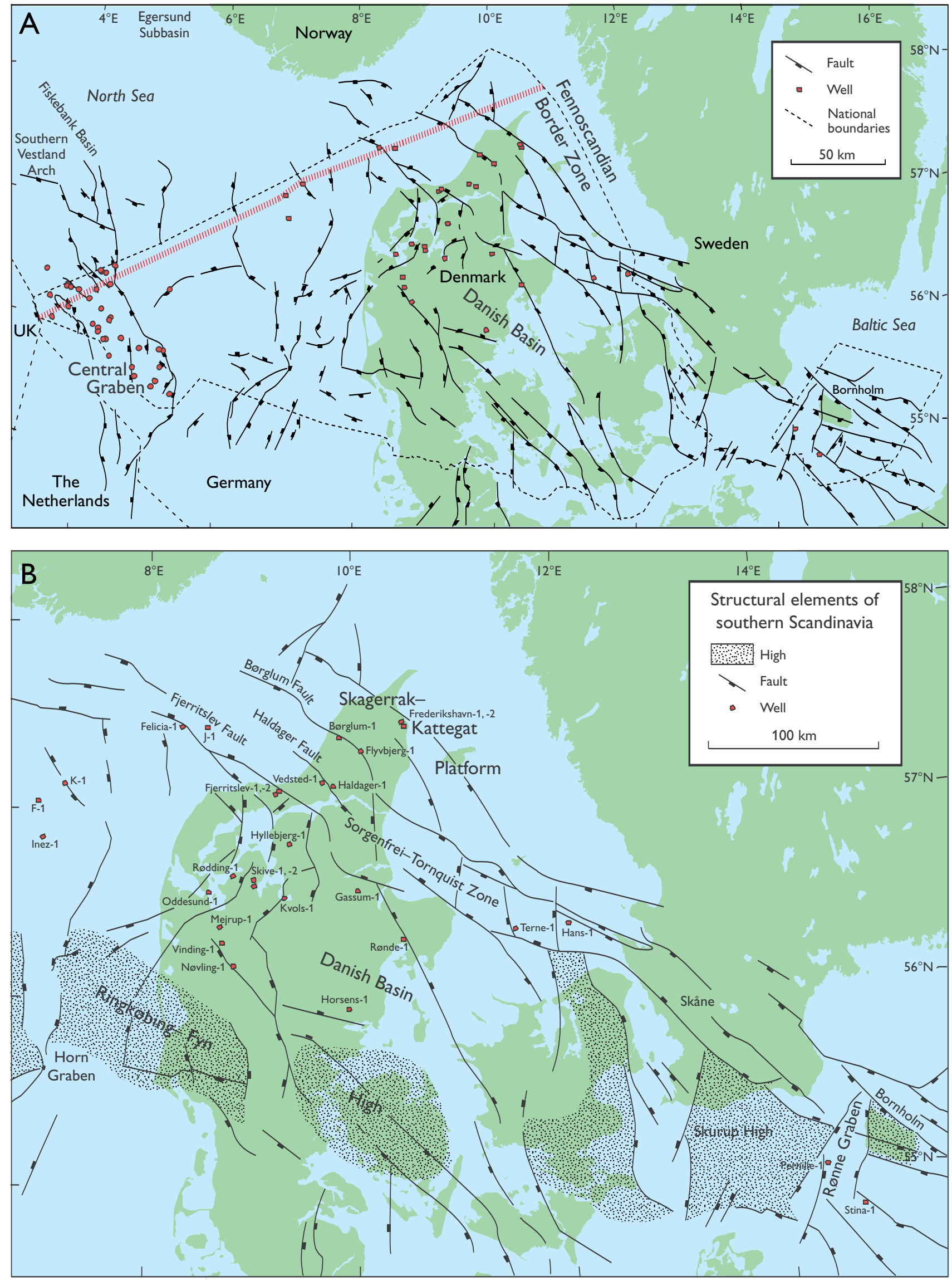


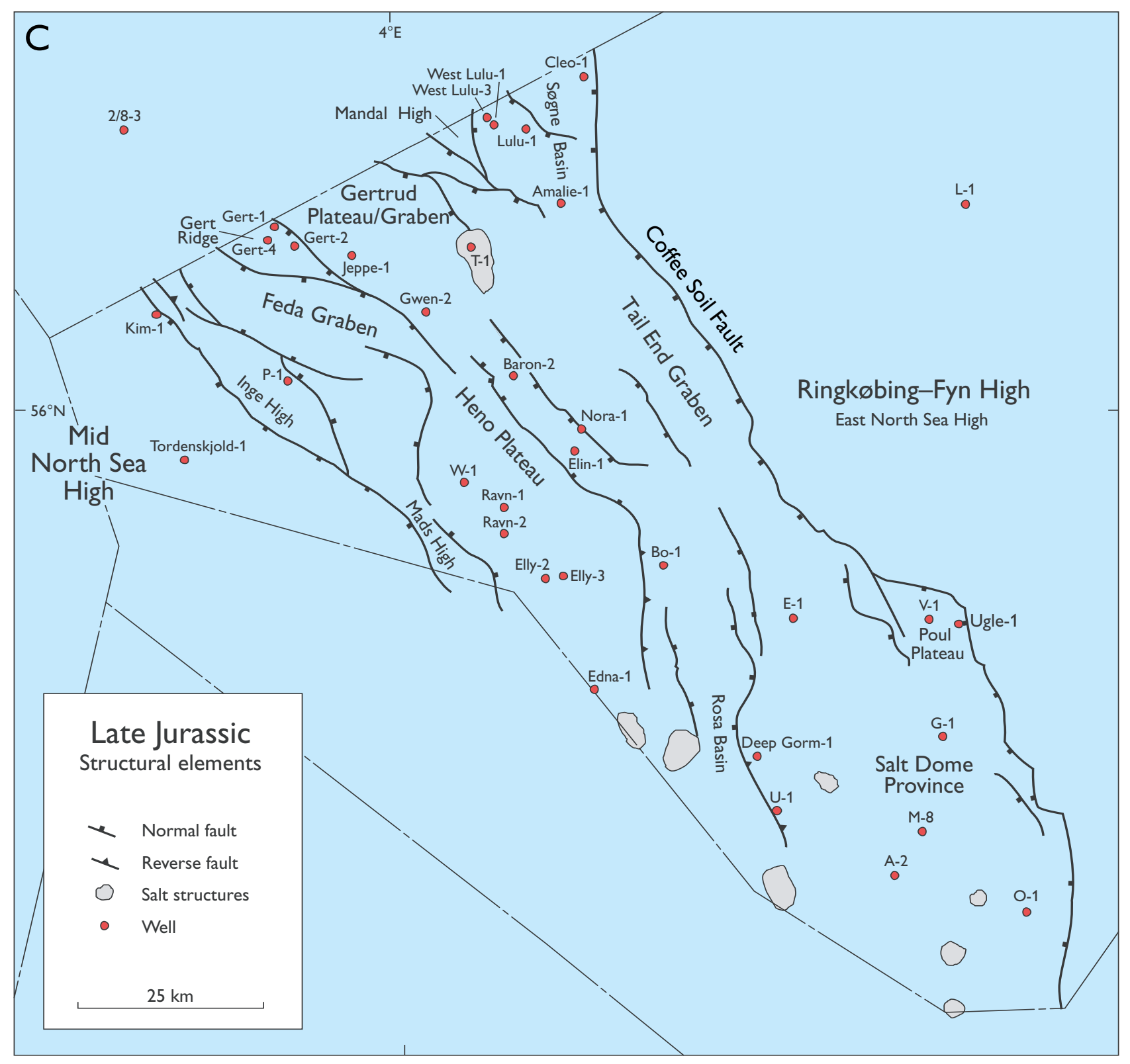

Fig. 1. A: Outline structure map showing the three main Mesozoic tectonic elements: the Central Graben, the Danish Basin and the Fennoscandian Border Zone. The red line parallel to the Denmark-Norway border indicates the location of the geosection in Fig. 3 . B: Simplified structural map of the Danish Basin with well locations. Modified from Nielsen (2003, this volume). C: Map of the Danish Central Graben showing the Late Jurassic structural elements and the location of wells mentioned in the text. Modified from Japsen et al. (2003, this volume).

mainly marine and paralic Jurassic deposits, and was repeatedly overstepped during the Jurassic. In the Kattegat area and northernmost Jylland, the zone includes two different structural elements, the Sorgenfrei-Tornquist Zone and the Skagerrak-Kattegat Platform (Figs 1B, 3; EUGENO-S Working Group 1988).

The Sorgenfrei-Tornquist Zone was established during Late Carboniferous - Early Permian times as a rift zone in conjunction with the Oslo Graben (Liboriussen et al. 1987; EUGENO-S Working Group 1988; Ro et al. 1990; Michelsen \& Nielsen 1991, 1993; Mogensen \& Korstgård 1993, 2003, this volume; Mogensen 1994, 1996; Vejbæk 1997). The zone was periodically active during the Mesozoic. Block faulting and increased subsidence rates prevailed in the Late Triassic - Early Jurassic and during latest Jurassic - earliest Cretaceous times, while inversion tectonism characterised Late Cretaceous - Early Cenozoic times. Slow subsidence occurred in 


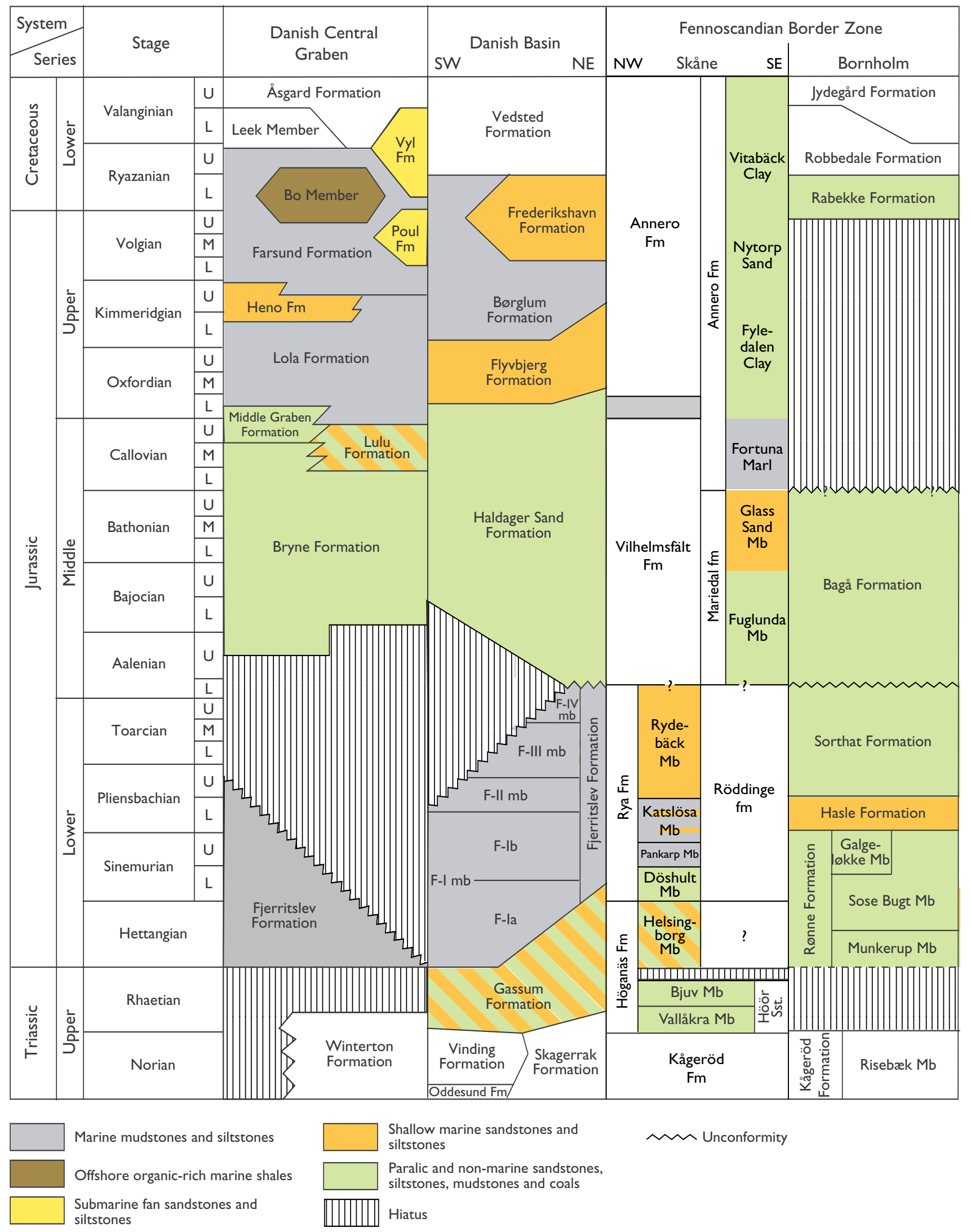

Fig. 2. Lithostratigraphic scheme of the Jurassic (including the uppermost Triassic and lowermost Cretaceous) of the Danish Central Graben, the Danish Basin and the Fennoscandian Border Zone (Bornholm and Skåne, southern Sweden). Colours (Jurassic units primarily) indicate overall depositional environments and facies. 

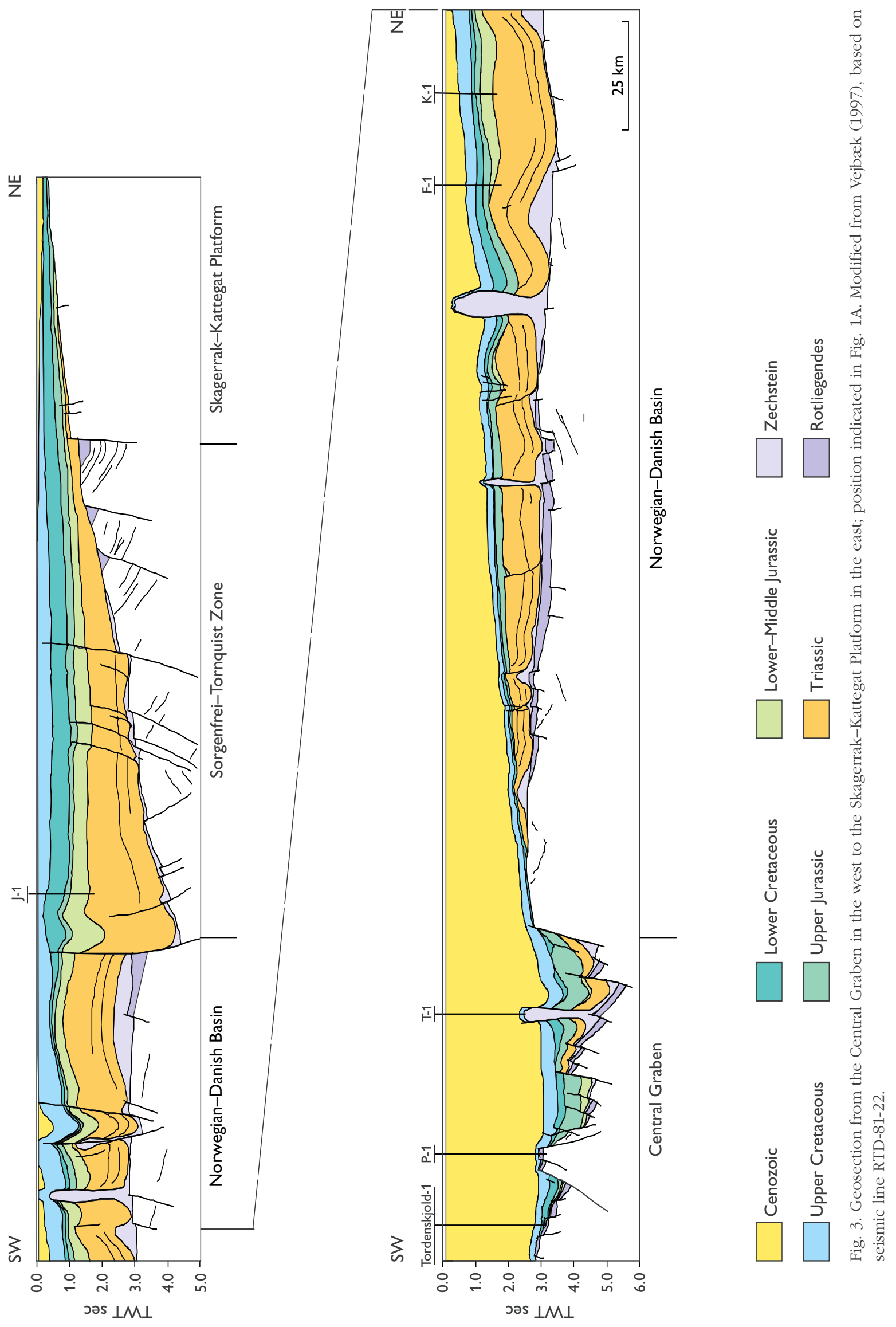
Middle Jurassic time (Nielsen 1995, 2003, this volume; Andsbjerg et al. 2001). The Skagerrak-Kattegat Platform was a stable area that was transgressed during the Jurassic and is characterised by eastwards thinning of the relatively undisturbed Mesozoic succession.

The Danish Basin, constituting the eastern part of the Norwegian-Danish Basin, is situated south-west of the Sorgenfrei-Tornquist Zone. The basin is bordered to the south by the ESE-WNW-trending Ringkøbing-Fyn High, which consists of a series of shallow fault blocks of Precambrian basement (Sorgenfrei \& Buch 1964). The high is of pre-Permian age and is separated from the Mid North Sea High by the north-south-oriented Central Graben (Fig. 1). The Ringkøbing-Fyn High acted as a submarine intra-basinal high during the Early Jurassic. Middle Jurassic uplift of the central North Sea affected the Ringkøbing-Fyn High, which was emergent throughout Middle and Late Jurassic times (Michelsen 1978a; Koch 1983; Ziegler 1990; Nielsen 2003, this volume). The high separates the Norwegian-Danish Basin in the north from the North German Basin in the south.

The Danish Basin, formerly described as the Danish Embayment (Sorgenfrei \& Buch 1964), and its extension to the west, the Norwegian-Danish Basin, began to subside in Permian times (Vejbæk 1989, 1997). It contains a thick succession of Jurassic deposits, generally comprising marine Lower Jurassic claystones, fluvial and paralic Middle Jurassic sandstones, and marine Upper Jurassic claystones and sandy claystones. There seems to have been open marine connections with basinal areas to the south, west and north during the Early Jurassic (Michelsen 1978a). After the mid-Jurassic uplift of the Ringkøbing-Fyn High, the connection to the mid-European basinal areas was mainly restricted to the Central Graben area in the west.

South of the Ringkøbing-Fyn High, in the northern part of the North German Basin, marine deposition probably only occurred prior to the mid-Jurassic uplift of the high. Subsequent erosion seems to have removed much of the Lower Jurassic deposits, which in the Danish area are only known from wells in the northeastern part of the basin.

The Central Graben is a complex structural feature, including a number of fault-bounded basins, highs and platforms (Fig. 1C), which possibly started to subside in the Early Permian (Ziegler 1975; Gowers \& Sæbøe 1985). However, it remains uncertain if there was a connection in the Late Permian between the northern and southern Zechstein basins through the graben (Vejbæk 1992). A minor angular unconformity separates the Triassic from the Lower Jurassic, indicating a
Late Triassic tectonic event. The Early Jurassic was characterised by regional subsidence and relative tectonic quiescence, and the Central Graben was a part of the larger North Sea Basin. Marine Lower Jurassic deposits equivalent to those known from the Danish Basin are present in the southern part of the graben. They were probably widely distributed in the North Sea Basin prior to Middle Jurassic uplift and erosion of the central North Sea area; the Lower Jurassic deposits, as preserved today, represent erosional remnants (Gowers \& Sæbøe 1985; Michelsen et al. 1992). The main rifting of the Central Graben took place in Middle and Late Jurassic times. Major fault-controlled subsidence occurred in the eastern part of the graben, along the bounding Coffee Soil Fault zone, and fluvial-deltaic Middle Jurassic sediments were deposited along the fault zone, probably representing the initial syn-rift deposits. Subsidence rates increased significantly during the Late Jurassic, and more than $4000 \mathrm{~m}$ of clay-dominated sediments were deposited in the eastern part of the graben. Wrenching led to considerable lateral variation in subsidence rates, and major depocentres developed such as the Tail End Graben and the Feda Graben (Møller 1986; Vejbæk 1992; Japsen et al. 2003, this volume). The depositional area gradually expanded to the west, and marine Upper Jurassic deposits cover the entire graben area (Michelsen et al. 1987; Damtoft et al. 1992; Johannessen et al. 1996).

\section{Lithostratigraphy}

Within the last forty years, a large number of lithostratigraphic units have been defined within the Jurassic successions of the Danish onshore and offshore areas (Larsen 1966; Bertelsen 1978; Michelsen 1978a, 1989a; Gravesen et al. 1982; Jensen et al. 1986). An overview of the lithostratigraphic units encountered in wells in the Danish onshore and offshore areas was presented by Nielsen \& Japsen (1991). All Jurassic formations are reviewed here, some formations are revised, and two new formations and two new members are defined (Fig. 2). The overall lithology, depositional environments, distribution, thickness and age are described.

The formations of Bornholm are primarily known from outcrops, and the definitions thus include sedimentary facies; information on gamma-log characteristics from shallow cored wells are also included to provide a basis for comparison with subsurface and offshore sections (Fig. 4). The formations in the Danish Basin and the Central Graben are only known from wells, mainly drilled for hydrocarbon exploration, and 
from reflection seismic data. The successions penetrated by wells are mainly represented by cuttings samples, and petrophysical logs are therefore used in the identification, delimitation and description of the subsurface formations. The descriptions including the lithology and log features (predominantly gamma-ray and sonic logs) are shown on figures with subsurface type sections or reference sections. Formal and informal members of certain formations are discussed briefly under the 'remarks' given to the respective formations. The formations from Bornholm are described first, followed by formations from the Danish Basin, and the lithostratigraphic section is concluded with the formations from the Danish Central Graben. Within each area, the formations are described in ascending stratigraphic order; with the exception of the uppermost formation in each area, only the lower boundary is described for each formation, the upper boundary being described under the succeeding formation. In borehole/well sections, the depths are given in relation to the land surface (Bornholm), the well reference level (typically Kelly Bushing (KB)) and mean sea level (MSL). Metric (SI) units are preferred, but wells drilled in feet are listed as such, relative to the well reference level, to ensure the accuracy of primary borehole data.

\section{Bornholm}

The Jurassic succession of Bornholm is referred to four formations, the Rønne, Hasle, Sorthat and Bagå Formations (Fig. 2), of which the Sorthat Formation is new and the Bagå Formation is revised. The four formations are included in the Bornholm Group of Gravesen et al. (1982). The Lower Cretaceous Rabekke Formation is not dealt with here, although it may reach down into the uppermost Jurassic.

\section{Rønne Formation}

History. The Rønne Formation was defined by Gravesen et al. (1982).

Type area. The cliffs on the south-west coast of Bornholm between Sønderborg and Næbbe Odde where the upper parts of the formation are exposed (Fig. 4; Gravesen et al. 1982). Type sections are defined for the two upper members only, the Sose Bugt Member and the Galgeløkke Member (Gravesen et al. 1982).

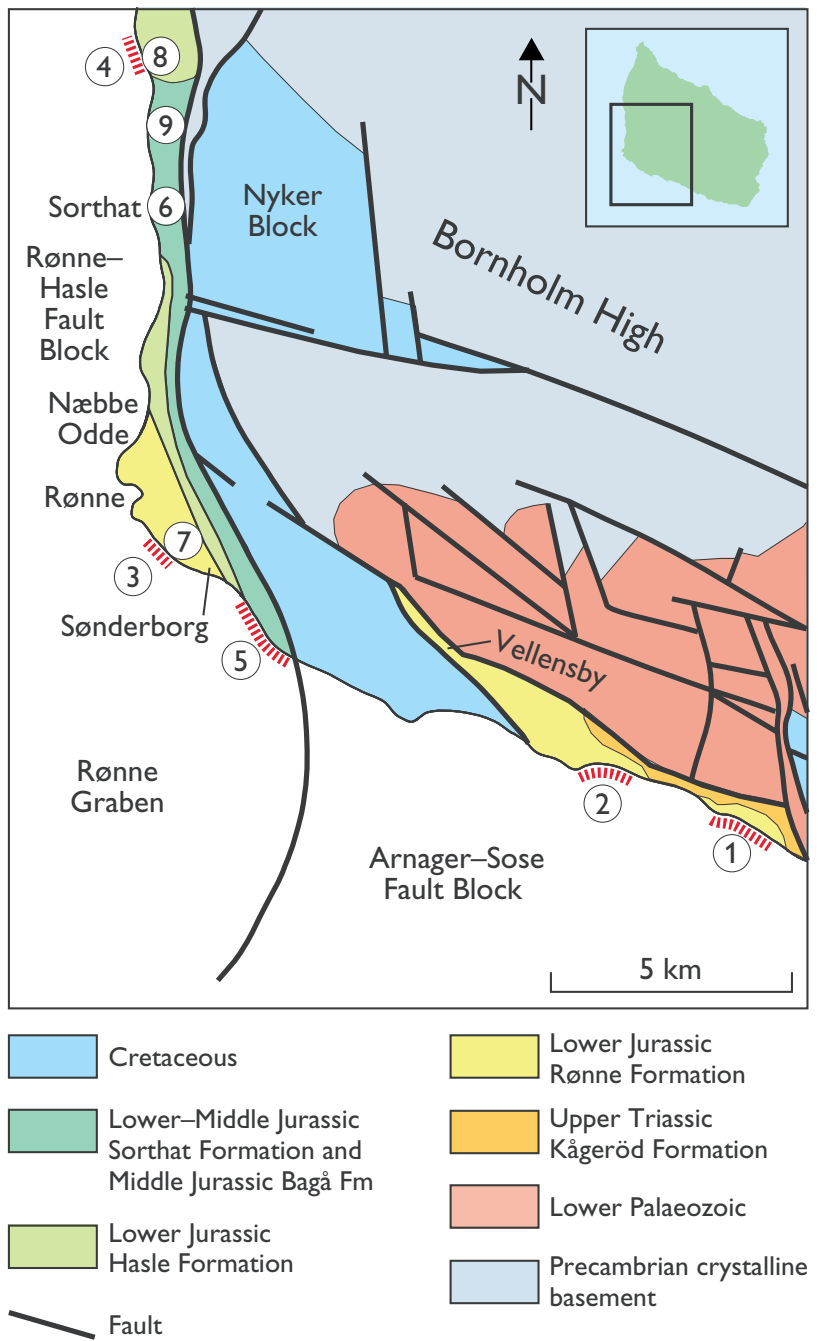

Fig. 4. Geological map of south-west Bornholm (see inset) showing the position of type localities, and type and reference sections. Localities marked with the red lines indicate extensive coastal exposures. 1, Munkerup coastal section, type locality of the Munkerup Member, Rønne Formation; 2, Sose Bugt coastal section, type section of the Sose Bugt Member, Rønne Formation; 3. Galgeløkke coastal section, type section of the Galgeløkke Member, Rønne Formation; $\mathbf{4}$, Hasle coastal section, type locality of the Hasle Formation; 5, Korsodde coastal section, reference section of the Sorthat and Bagå Formations; 6, Hasle Klinkerfabrik clay pit, type section of the Bagå Formation; 7, position of the Galgeløkke-1 and -2 core wells, reference section of the Rønne Formation; $\mathbf{8}$, position of the Hasle-1 core well, reference section of the Hasle Formation; 9, position of the Levka-1 well, reference section of the Hasle Formation and type section of the Sorthat Formation. Modified from Gravesen et al. (1982).

Reference section. The combined cored section of the Galgeløkke-1 and -2 wells is designated as a reference section to complement the discontinuous exposures and to facilitate correlation to other subsurface and off- 
Galgeløkke-1, -2 composite core log

Reference section: Rønne Formation
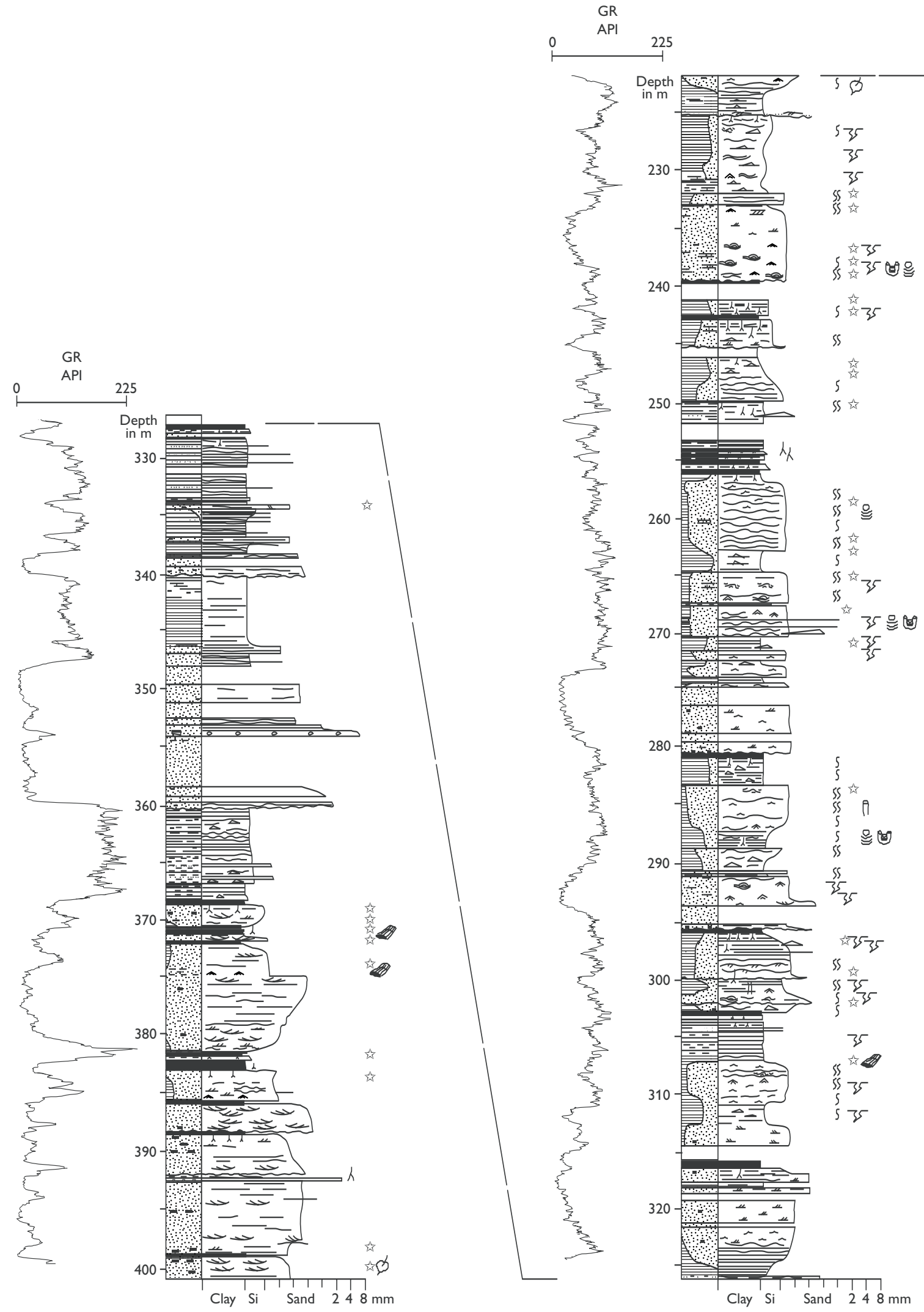

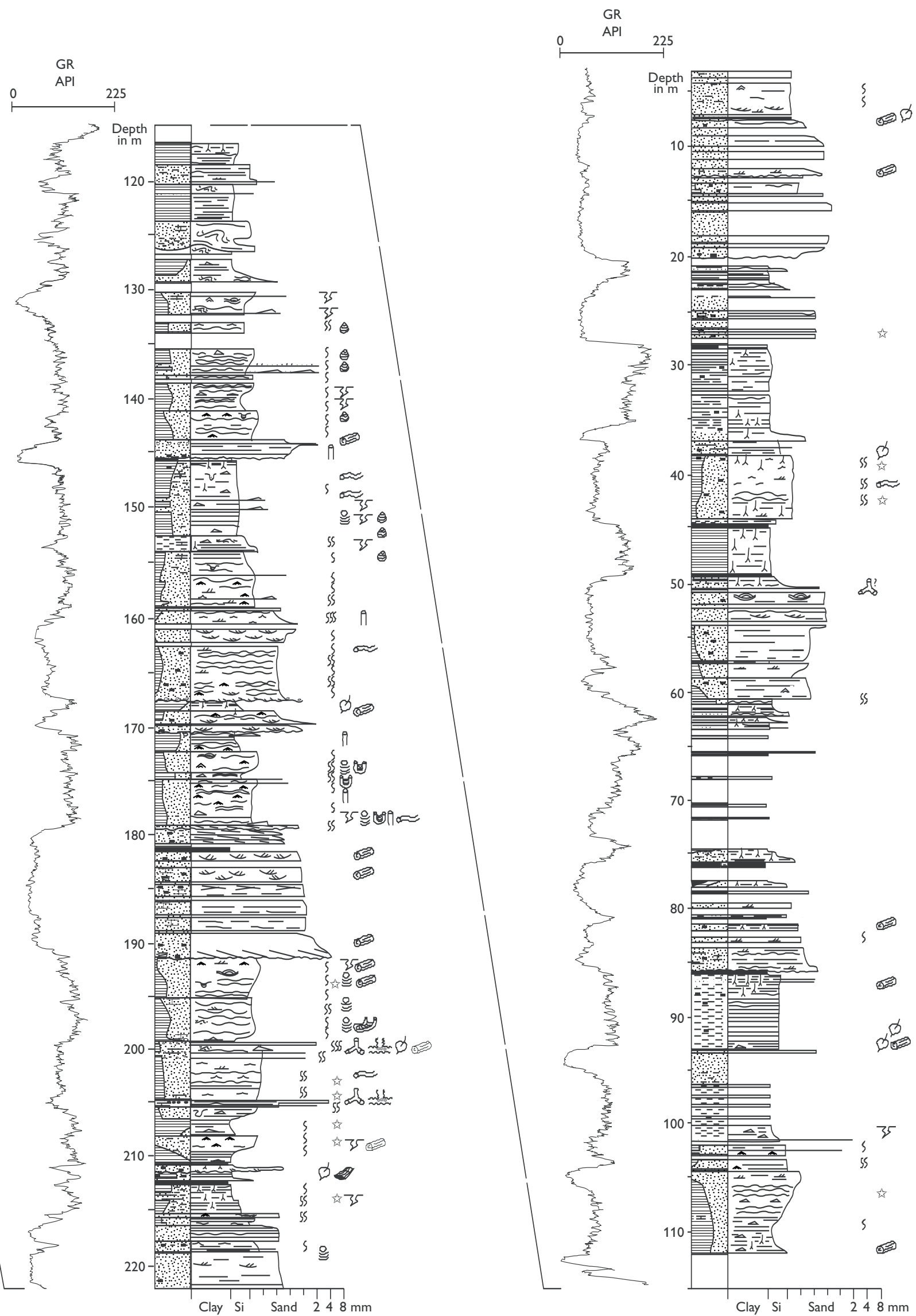


\section{Legend:}

\section{Sedimentological logs}

\begin{tabular}{|c|c|c|}
\hline Lith & ology & \\
\hline & Mudstone & 合 clast \\
\hline$E=$ & Siltstone & $\Theta$ clast \\
\hline$E$ & Heterolith, mud/sand (50\%) & \\
\hline & Sandstone & clast \\
\hline$\because$ & Conglomerate & $+\bigcirc$ Basement clast \\
\hline & Pebble/granule lags & \\
\hline & Coal & clast \\
\hline & Calcareous cement & \\
\hline & Pyritic concretions & \\
\hline 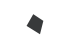 & Carbonaceous detritus & \\
\hline & Mudstone chips & \\
\hline
\end{tabular}

\section{Sedimentary structures \\ Erosional surface \\ Parallel bedding/lamination \\ IIIIII Planar cross-bedding \\ VI/ Cross-bedding with mudstone drapes \\ 2 Cross-bedding with double mudstone drapes \\ Trough cross-bedding \\ Low-angle cross-bedding \\ Hummocky cross-stratification \\ Gor Gutter casts \\ Cross-lamination and climbing ripples \\ $\nVdash$ Bimodal current-ripple lamination \\ त $\hat{A}$ Wave ripples \\ 그 Flaser bedding \\ 佘 Wavy bedding \\ $\Delta$ Lenticular and silt-streaked bedding \\ $\approx$ Disturbed bedding \\ $\mathcal{V}$ Load structures \\ Л3) Water escape structures \\ VI Synaeresis cracks}

\section{Stratigraphic logs}

\section{Biogenic structures}

\begin{tabular}{|c|c|}
\hline$\Gamma$ & Bioturbation \\
\hline $5-555$ & Degree of bioturbation \\
\hline & Chondrites isp. \\
\hline & Diplocraterion isp. \\
\hline & Equilibrichnion isp. \\
\hline & Rhizocorallium isp. \\
\hline & Skolithos isp. \\
\hline & Teichichnus isp. \\
\hline & Thalassinoides isp. \\
\hline & Horizontal burrows \\
\hline & Large burrows \\
\hline & Rootlets \\
\hline
\end{tabular}

Fossils

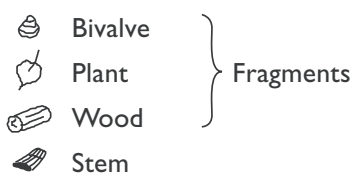

\begin{tabular}{|c|c|}
\hline & Claystone \\
\hline & Siltstone \\
\hline & Clayey Sandstone \\
\hline & Silty sandstone \\
\hline & Sandstone \\
\hline & Conglomerate \\
\hline & Scattered gravel clasts \\
\hline & Coal bed and clasts \\
\hline & Limestone bands \\
\hline & Limestone \\
\hline & Marlstone \\
\hline & Dolomite bands \\
\hline & Volcanic rocks \\
\hline & Cored section \\
\hline
\end{tabular}

Preceding pages and above:

Fig. 5. Composite core log of the Rønne Formation in the Galgeløkke-1 and -2 wells, located in the Rønne-Hasle Fault Block just south of the town of Rønne on the west coast of Bornholm, c. $300 \mathrm{~m}$ ENE of the coastal cliff at Galgeløkke and just west of the eastern bounding fault of the Rønne Graben; reference section for the Rønne Formation. No formal subdivision into members is attempted for this section although it is probably largely within the Sose Bugt Member. The formation was cored from $400.7-3.2 \mathrm{~m}$ b. surface; the base of the formation was not penetrated. The Galgeløkke-1 well was terminated at $123.75 \mathrm{~m} \mathrm{~b}$. surface due to technical problems; coring was resumed from $120 \mathrm{~m}$ to $400.7 \mathrm{~m}$ in the Galgeløkke-2 well drilled $3 \mathrm{~m}$ from Galgeløkke-1 (Nielsen 1987). Note that to facilitate comparison of the shallow cored well sections with outcrop sections on Bornholm, composite logs are organised with base to the lower left and top to the upper right. This is the reverse of that typically adopted for deep wells (e.g. Figs 11, 16, 26). Modified from Nielsen (1995). The accompanying legend is applicable to all subsequent sedimentological and stratigraphic logs. shore well sections. The wells were drilled at the same locality, south of the town of Rønne and c. $300 \mathrm{~m} \mathrm{ENE}$ of the coastal cliff at Galgeløkke where the type section of the Galgeløkke Member is exposed (Gravesen et al. 1982; Nielsen 1995). The cored wells encountered almost $400 \mathrm{~m}$ of the Rønne Formation $(3.2-400.7 \mathrm{~m}$ b. surface) and provided continuous cores and a gammaray log (Fig. 5). The type section of the Galgeløkke Member overlies the cored well sections with a stratigraphic gap of some tens of metres, as interpreted from map evidence and the dip of the exposed strata (Gry
1969; Jensen \& Hamann 1989; Nielsen 1995). The base of the Rønne Formation was not reached by the wells; the upper boundary with the overlying Hasle Formation was cored in the Hasle-1 well (Fig. 6).

Lithology and environment. The Rønne Formation consists of a wide variety of lithologies dominated by laminated or massive mud, heteroliths of mud and finegrained sand, fine- to medium-grained sand, and thin coal beds with rootlets. Deposition took place in paralic and marine environments including coastal plains, 
lakes, fluvial channels, tidal channels, tidal flats, marine shoreface and restricted offshore.

Log characteristics. The gamma-ray logs from the Galgeløkke-1, -2 and Hasle-1 wells show a highly variable pattern reflecting the wide variety of lithologies, with sand displaying blocky, coarsening-upwards (i.e. values decrease upwards) and fining-upwards (values increase upwards) trends. Mud is indicated by relatively uniform high values, while the common heteroliths are shown by intermediate, variable values.

Lower boundary. Onshore, the formation rests unconformably on Triassic or Cambrian strata. The lower boundary is defined by a change from red, green and variegated clay and greenish sandstones lacking carbonaceous detritus of the Triassic Risebæk Member (Kågeröd Formation) or from Cambrian quartzitic sandstones to light and dark grey to black clay with abundant carbonaceous detritus and subordinate sand of the Rønne Formation. Offshore, in the Pernille- 1 and Stina-1 wells, the Rønne Formation (Munkerup Member) overlies Upper Triassic strata, probably of Rhaetian age, mainly consisting of slightly calcareous to marly brownish claystones; the boundary is tentatively placed at the change to non-calcareous claystones with organic detritus.

Distribution and thickness. The Rønne Formation may be up to $500 \mathrm{~m}$ thick in the eastern part of the Rønne Graben near the town of Rønne (Nielsen 1995). The formation extends offshore in the Rønne Graben as shown by the Pernille-1 and Stine-1 wells (Fig. 1C, see also Fig. 31).

Age. The Rønne Formation is essentially of HettangianSinemurian age but may extend into the earliest Pliensbachian (Gry 1969; Koppelhus 1991; Surlyk et al. 1995; Donovan \& Surlyk 2003, this volume). The Munkerup Member is of Early Hettangian age. The Sose Bugt Member is of Late Hettangian - Late Sinemurian or earliest Pliensbachian age in the Arnager-Sose Block, while it may be limited to the Late Hettangian - Early Sinemurian in the Rønne-Hasle Fault Block, where the Galgeløkke Member probably spans the Late Sinemurian.

Subdivisions. Gravesen et al. (1982) subdivided the formation, in ascending stratigraphic order, into the Munkerup Member, the Sose Bugt Member and the Galgeløkke Member (Fig. 2).

The Munkerup Member is known from numerous small clay pits, long since infilled. The description of the member is therefore based on old literature, and a type section has not been measured (Gravesen et al. 1982). The member is dominated by grey to black clay with subordinate thin beds of red, brown and white clay, and sandstone. Carbonaceous detritus and plant fossils are abundant in the clays, locally forming coal laminae or thin coal beds. The sandstones are very fine-grained, white to yellowish. In addition to the occurrences at the type locality on the coast at Munkerup and at Vellensby, where a reference section has been defined in a shallow borehole, the member seems to be present in the Pernille-1 and Stina-1 wells in the Rønne Graben (Fig. 1C, see also Fig. 31; Nielsen 1995). In these wells, c. 50 $\mathrm{m}$ of mainly grey to olive grey and light grey clay is interbedded with fine- to medium-grained sand containing a mixed assemblage of Early Jurassic and reworked Triassic spores and pollen comparable to that of the onshore Munkerup Member (Koppelhus 1991; Nielsen 1995). According to Gry (1969) the thickness of the Munkerup Clay onshore is $20 \mathrm{~m}$ although the upper boundary is not seen.

The Sose Bugt Member is recognised onshore Bornholm in both the Arnager-Sose and Rønne-Hasle Fault Blocks, and a type section has been defined from the outcrop at Sose Bugt (Fig. 4; Gravesen et al. 1982; Surlyk et al. 1995). The member appears to be thickly developed offshore in the Rønne Graben (Nielsen 1995). It is dominated by alternating thin beds of fine-grained, crosslaminated sand, commonly with abundant organic detritus, and thin beds of grey laminated clay or heteroliths of sand and clay. Rootlet horizons and thin coal beds are common. Fine-grained and medium- to coarse-grained sand units, up to $12 \mathrm{~m}$ thick, with cross-lamination and cross-bedding are common in the Rønne-Hasle Fault Block as shown by the Galgeløkke-2 well (Fig. 5).

The Galgeløkke Member is dominated by light grey to white or yellowish, cross-laminated, fine-grained sand or heteroliths showing wavy and flaser-laminated sand and clay, particularly in the lower part. Large-scale cross-bedded medium- to coarse-grained sand beds with tidal bundles and mud couplets (Sellwood 1972; Tyge 1990) dominate the middle part of the member. Thin coal beds and carbonaceous clays with rootlets occur, as well as organic detritus. The type section of the member is defined in the Rønne-Hasle Fault Block (Fig. 4), and the member is also present offshore in the Rønne Graben (Gravesen et al. 1982; Nielsen 1995). It has, however, not been possible on the basis of the available data to define the boundary between the Sose Bugt and Galgeløkke Members with confidence in the Galgeløkke-1, -2, Pernille-1 and Stina-1 wells. The member is probably not present in the Arnager-Sose Block 

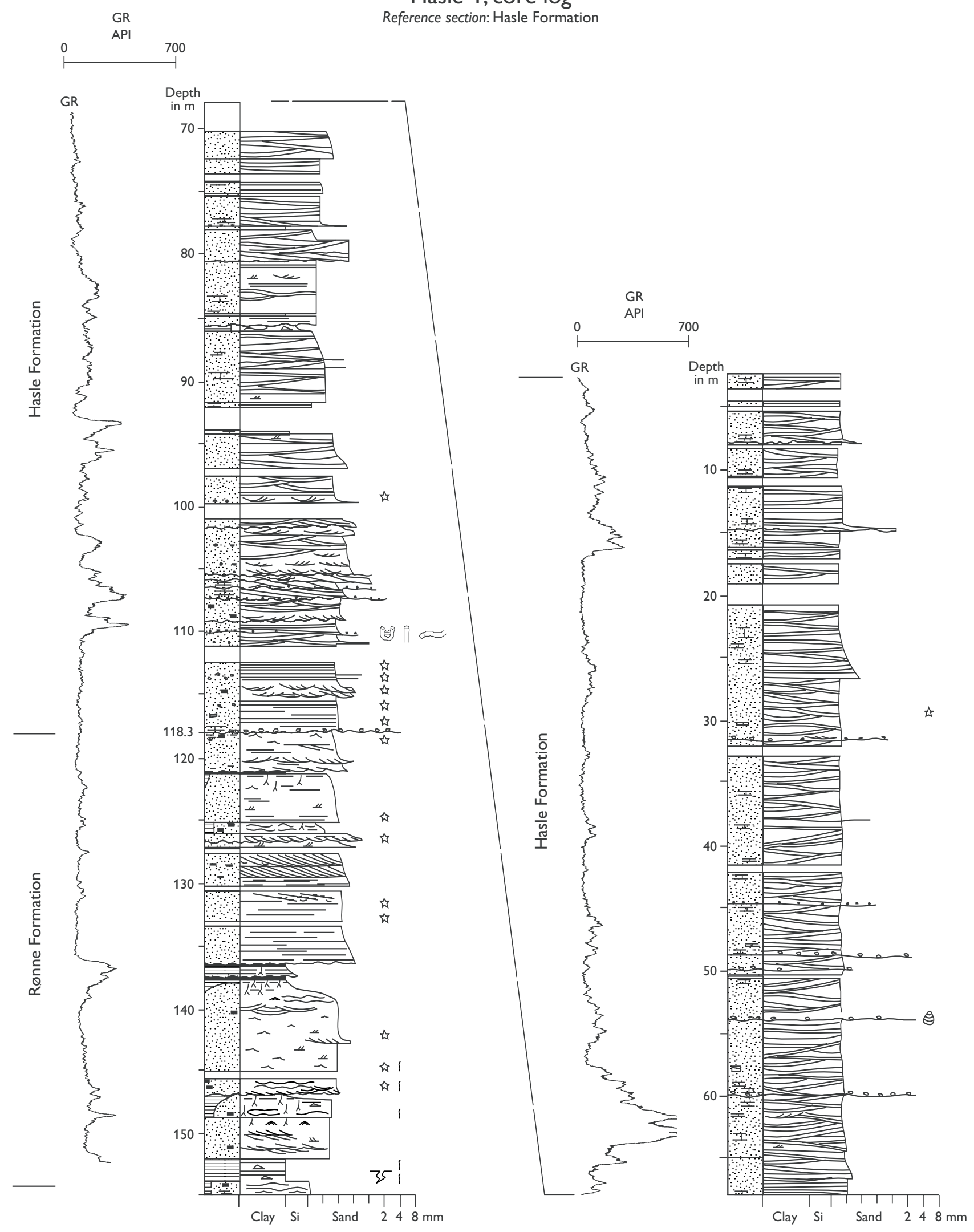
(Nielsen 1995; Surlyk et al. 1995), as originally supposed (Gravesen et al. 1982).

\section{Hasle Formation}

History. The Hasle Formation was defined by Gravesen et al. (1982).

Type area. The coastal cliff, south of Hasle town, Bornholm (Fig. 4). A type section has not been measured, but representative sections of the formation may be found in Surlyk \& Noe-Nygaard (1986).

Reference section. The cored Hasle-1 well (2.6-155.0 m b. surface), drilled c. $1.1 \mathrm{~km}$ south of the Hasle harbour (Fig. 4), provides continuous cores and a gamma-ray log from the lower-middle part of the Hasle Formation and illustrates the lower boundary with the Rønne Formation (Fig. 6). The cored Levka-1 well drilled between the type area of the Hasle Formation and the type section of the Baga Formation in the Hasle Klinkerfabrik clay pit, c. $2.5 \mathrm{~km}$ south of the Hasle harbour and c. $1 \mathrm{~km}$ north of the clay pit, provides cores from the middle-upper part of the Hasle Formation (Fig. 7). The two wells are designated as reference sections to facilitate correlation to other subsurface and offshore well-sections; together they illustrate the entire formation with some overlap.

Lithology and environment. At outcrop, the Hasle Formation consists of rusty yellow to brownish (dark greenish when unweathered), coarse-grained siltstones and very fine-grained sandstones with swaley to hummocky cross-stratification and marked erosion surfaces draped with small pebble lags. Thin poorly sorted gravels, greenish grey and brown clays and clay-ironstones

\section{Facing page:}

Fig. 6. Hasle-1 well, located in the Rønne-Hasle Fault Block, north of the town of Rønne on the west coast of Bornholm, just west of the eastern bounding fault of the Rønne Graben (Nielsen 1987); reference section for the Hasle Formation. The lower $c .37 \mathrm{~m}$ of the cored section is referred to the Rønne Formation; the Hasle Formation was cored from 118.3-2.6 m b. surface. The upper part of the Hasle Formation is not represented in Hasle-1, but is cored in Levka-1 (see Fig. 7). Note that the scale on the gamma-ray log differs from the Galgeløkke-1, -2 and Levka-1 wells. Modified from Nielsen (1995); for legend, see Fig. 5. occur locally (Gravesen et al. 1982; Surlyk \& NoeNygaard 1986). The sandstones are intercalated with fossiliferous clays in the area of the town of Rønne and the south coast at Stampe $\AA$ (northern end of the Korsodde section, see Fig. 4), and a diverse marine fauna including numerous ammonites has been described from the clays (Malling \& Grönwall 1909; Malling 1911, 1914, 1920; Höhne 1933; Donovan \& Surlyk 2003, this volume). Clay beds seem to be absent in the type area to the north as clays were not encountered in the Hasle-1 and Levka-1 wells which in combination illustrate the entire Hasle Formation (Figs 6, 7). Deposition took place in a storm-dominated shoreface to offshore environment (Surlyk \& Noe-Nygaard 1986).

Log characteristics. The gamma-ray log from the Hasle-1 well (Fig. 6) shows intervals with relatively uniform low readings interrupted by log spikes that locally show extremely high values; such high values in the sandstones are caused by concentrations of uranium and thorium (Nielsen 1995).

Lower boundary. The formation conformably overlies the Rønne Formation and is marked by a change from largely unconsolidated heterolithic sand and clay with carbonaceous detritus to indurated limonitic brownish (weathered) or dark greenish (unweathered) sandstones or thick clay beds containing marine macrofossils. In the Hasle-1 reference section, the base of the Hasle Formation is defined at a marked pebble-strewn surface interpreted as a ravinement surface capping crossbedded and flaser-laminated sandstones with coal particles of the underlying Rønne Formation (Fig. 6, $118.3 \mathrm{~m}$; Nielsen 1995).

Distribution and thickness. The formation is probably up to $140 \mathrm{~m}$ thick in the type area and seems to be present offshore in the Stina-1 well in the southern part of the Rønne Graben in a slightly more fine-grained, clayey facies (see Fig. 31; Nielsen 1995).

Age. The formation is of Early Pliensbachian age (Donovan \& Surlyk 2003, this volume).

\section{Sorthat Formation}

new formation

History. The coal-bearing clays and sands that overlie the Hasle Formation in the Rønne-Hasle Fault Block have 


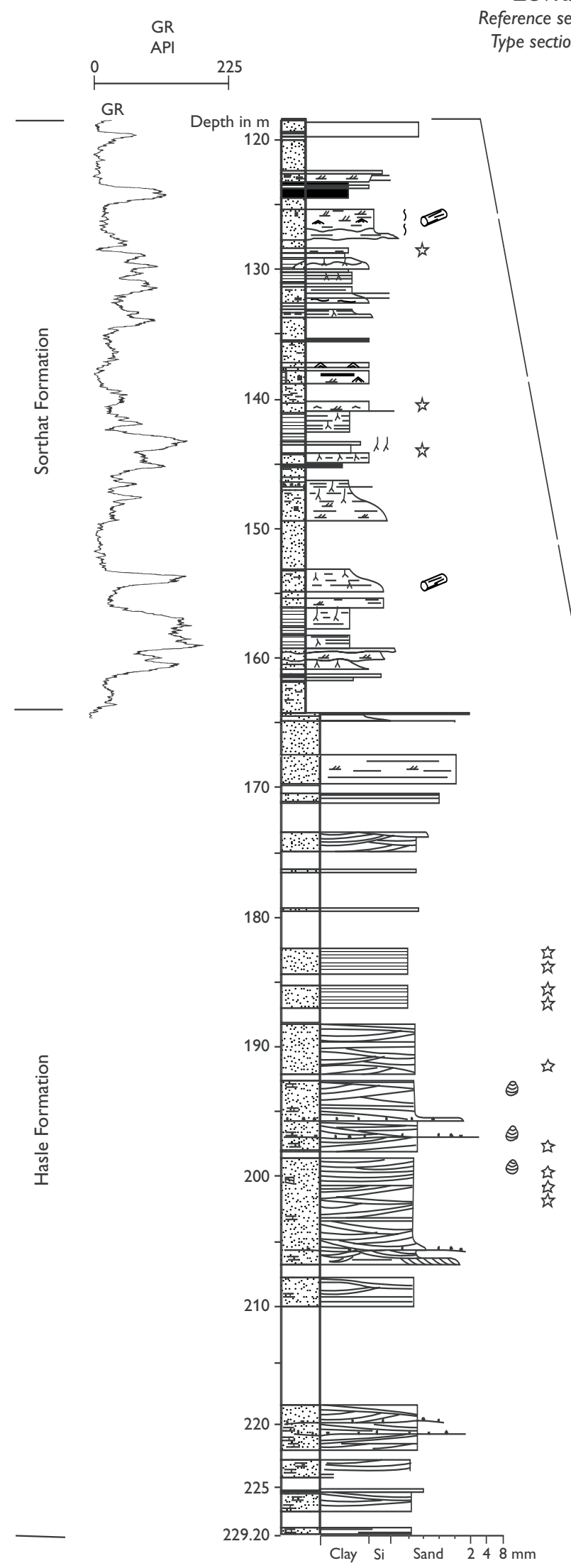

Levka-1, core log

Reference section: Hasle Formation

Type section: Sorthat Formation

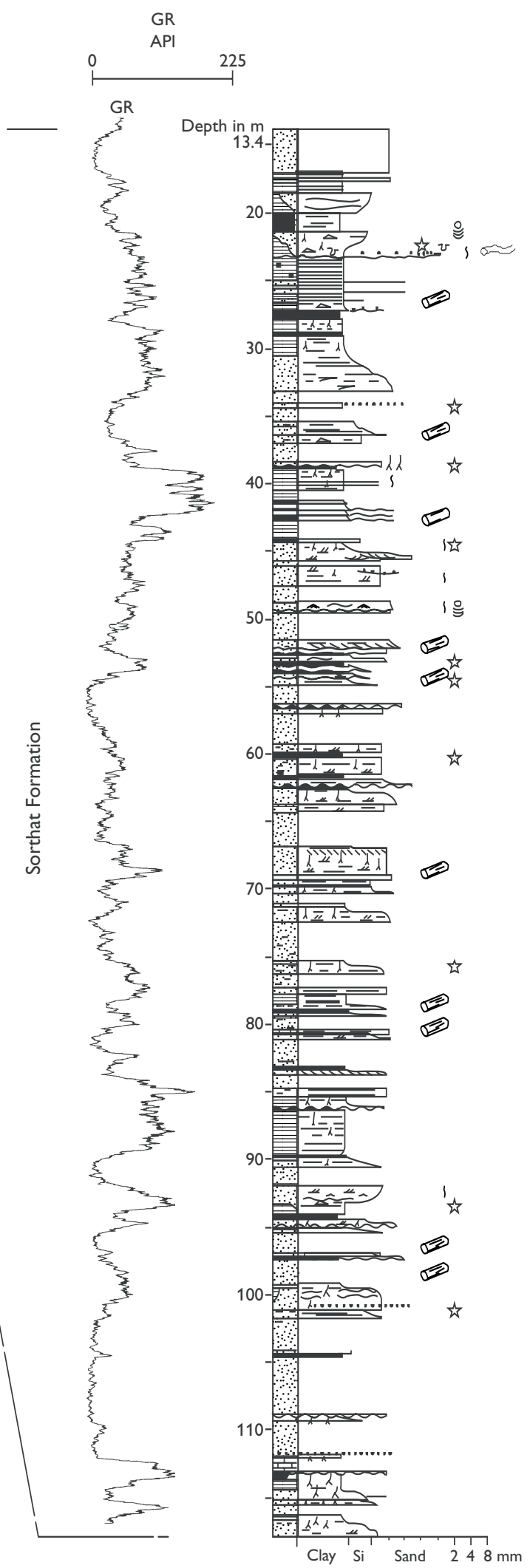


been referred to as the Levka, Sorthat and Bagå beds in older literature (reviewed by Gry 1969). A detailed stratigraphic interpretation of the beds has been difficult to achieve owing to complicated block faulting and folding, scattered outcrops and the absence of marine fossils and distinct marker beds. Based on the content of megaspores, Gry (1969) referred all three units to the Middle Jurassic with the Levka and Sorthat beds being roughly contemporaneous, and the Baga beds being possibly slightly younger. Gravesen et al. (1982) defined the Bagå Formation to include the coal-bearing clays and sands of the Levka, Sorthat and Baga beds and the coal-bearing strata at Korsodde and Onsbæk (northern end of the Korsodde section as indicated on Fig. 4). Preliminary palynological investigations of samples from the Levka-1 core-well and the Korsodde section suggested the presence of Upper Pliensbachian strata (E.B. Koppelhus in: Nielsen 1987; Koppelhus 1988; Nielsen \& Koppelhus 1989). A reassessment of the megaspore collections of H. Gry demonstrated the presence of several megaspore species from the Bagå Formation (sensu Gravesen et al. 1982) that suggest the presence of Toarcian-Aalenian strata, although their long range precluded a definite dating (Koppelhus \& Batten 1992). A thorough palynological-sedimentological study of all available exposures and cores from the Lower-Middle Jurassic has revealed that the marine Lower Pliensbachian sandstones of the Hasle Formation are overlain by a succession referable to the Levka and Sorthat beds that comprises bioturbated sands, heteroliths and clays with thin coal seams containing relatively diverse brackish-marine dinoflagellate assemblages indicative of the Upper Pliensbachian, Toarcian and possibly Lower Aalenian (Koppelhus \& Nielsen 1994). These paralic deposits are overlain by a succession equivalent to the Baga beds comprising crevasse and fluvial gravels and sands, lacustrine clays, carbonaceous clays and coals belonging to the Upper Aalenian? and Bajocian-Bathonian. These new data confirm that the Levka and Sorthat beds are lithologically different from the Bagå beds. Thus the Levka

\section{Facing page:}

Fig. 7. Levka-1 well, located in the Rønne-Hasle Fault Block north of the town of Rønne on the west coast of Bornholm, just west of the eastern bounding fault of the Rønne Graben (Fig. 4; Nielsen 1987); type section for the new Sorthat Formation. The formation was cored from 164.6-13.4 m b. surface. A gammaray log was not recorded from the Hasle Formation. Modified from Nielsen (1995); for legend, see Fig. 5 and Sorthat beds are here included in the new Sorthat Formation, and the Bagå Formation is revised to include the Bagå beds only. Both formations are included in the Bornholm Group of Gravesen et al. (1982). The section measured from the Sorthat beds by Gravesen et al. (1982, fig. 24) covers part of the new Sorthat Formation.

Name. After the locality of Sorthat on the west coast of Bornholm, between the towns of Hasle and Rønne, where the formation was previously exposed (Fig. 4; Gry 1969; Gravesen et al. 1982; Nielsen 1995).

Type section. The shallow Levka-1 core-well is selected as the type section as no exposures are currently available in the Sorthat area (Fig. 4); this well was drilled between the type area of the Hasle Formation and the type section of the Bagå Formation in the Hasle Klinkerfabrik clay pit, c. $2.5 \mathrm{~km}$ south of the Hasle harbour and $c .1 \mathrm{~km}$ north of the clay pit. The section from $13.4-164.6 \mathrm{~m} \mathrm{~b}$. surface is represented by both cores and a gamma-ray log (Fig. 7).

Reference section. An intermittently exposed succession, 130-140 m thick at Korsodde on the south-west coast of Bornholm is selected as the reference section (Fig. 8).

Lithology and environment. The lithology of the Sorthat Formation is highly variable. The cores and gamma log from the lower $c .112 \mathrm{~m}$ of the formation in the Levka-1 well reveal sharp-based, fining-upwards units, 3-14 m thick, consisting of coarse-grained, occasionally pebbly sand, overlain by muddy, carbonaceous, micaceous, fine- to medium-grained sand, laminated to homogeneous clay and coal seams with rootlets (Fig. 7). Most of the cored sand shows parallel lamination with subordinate thin beds with cross-bedding, cross-lamination and flaser lamination. Large plant fragments and small quartz pebbles are common. Occurring between the fining-upwards units are thinly interbedded sand and clay with rootlets and thin coal seams. Marine palynomorphs are not found and the interval is interpreted as having been deposited on a coastal or delta plain with fluvial channels, lakes and swamps (Koppelhus \& Nielsen 1994). The upper $c .40 \mathrm{~m}$ of the well-section consist of cross-bedded, cross-laminated, wave-rippled and bioturbated sand and heteroliths with sporadic synaeresis cracks, pyrite nodules, Planolites isp. and Teichichnus isp. burrows and brackish-marine palynomorphs. Fining-upwards successions of sand, clay and coal seams are also represented and are characterised 


\section{Korsodde coastal section}

Reference section: Sorthat Formation

Reference section: Bagå Formation
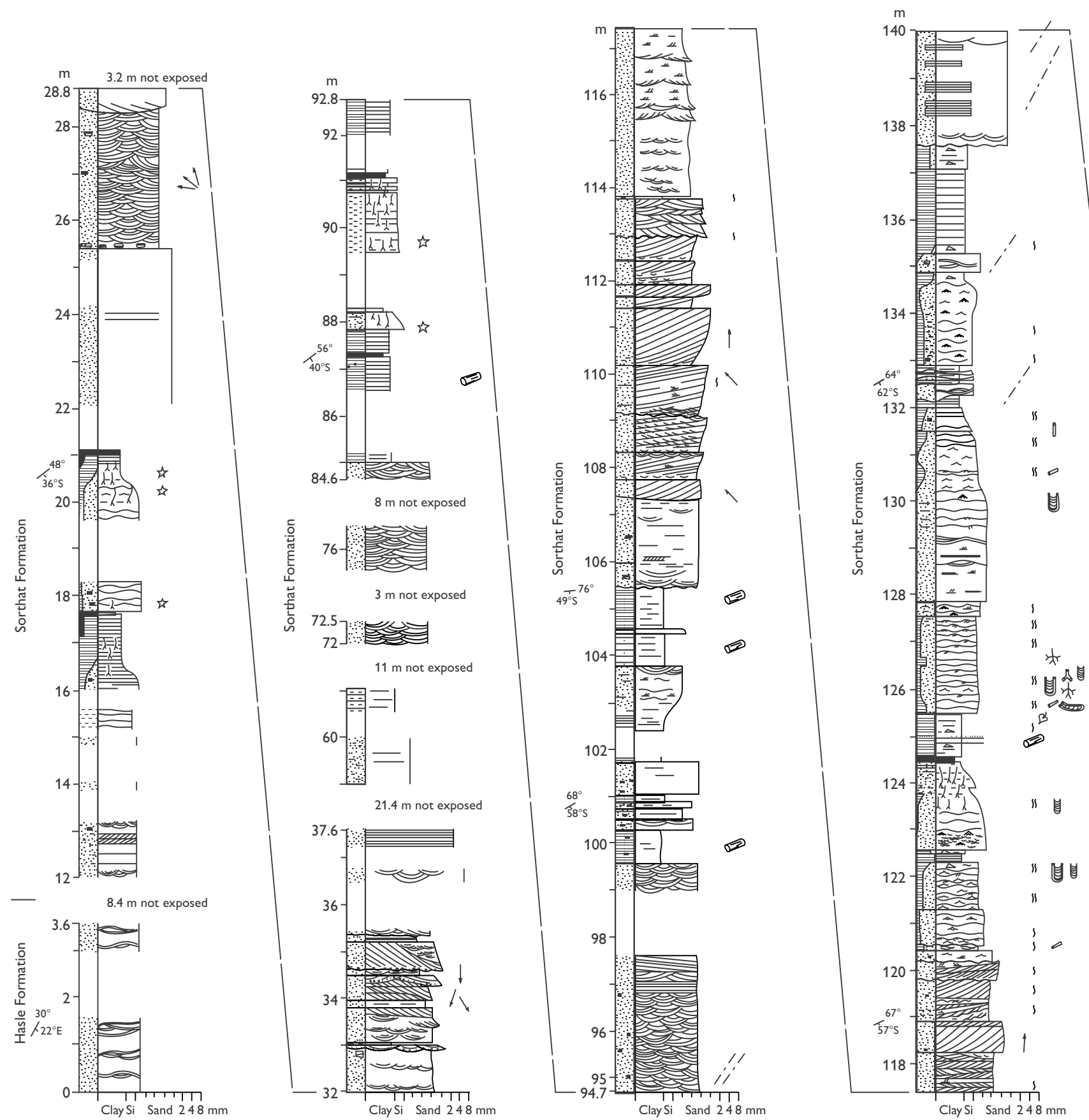

Fig. 8. Coastal section from south-west Bornholm, Rønne-Hasle Fault Block, close to the eastern bounding fault of the Rønne Graben; reference section of the new Sorthat Formation. The formation overlies the Hasle Formation, but the formation boundary occurs within an unexposed interval of $8.4 \mathrm{~m}$. Modified from Koppelhus \& Nielsen (1994); for legend, see Fig. 5. 

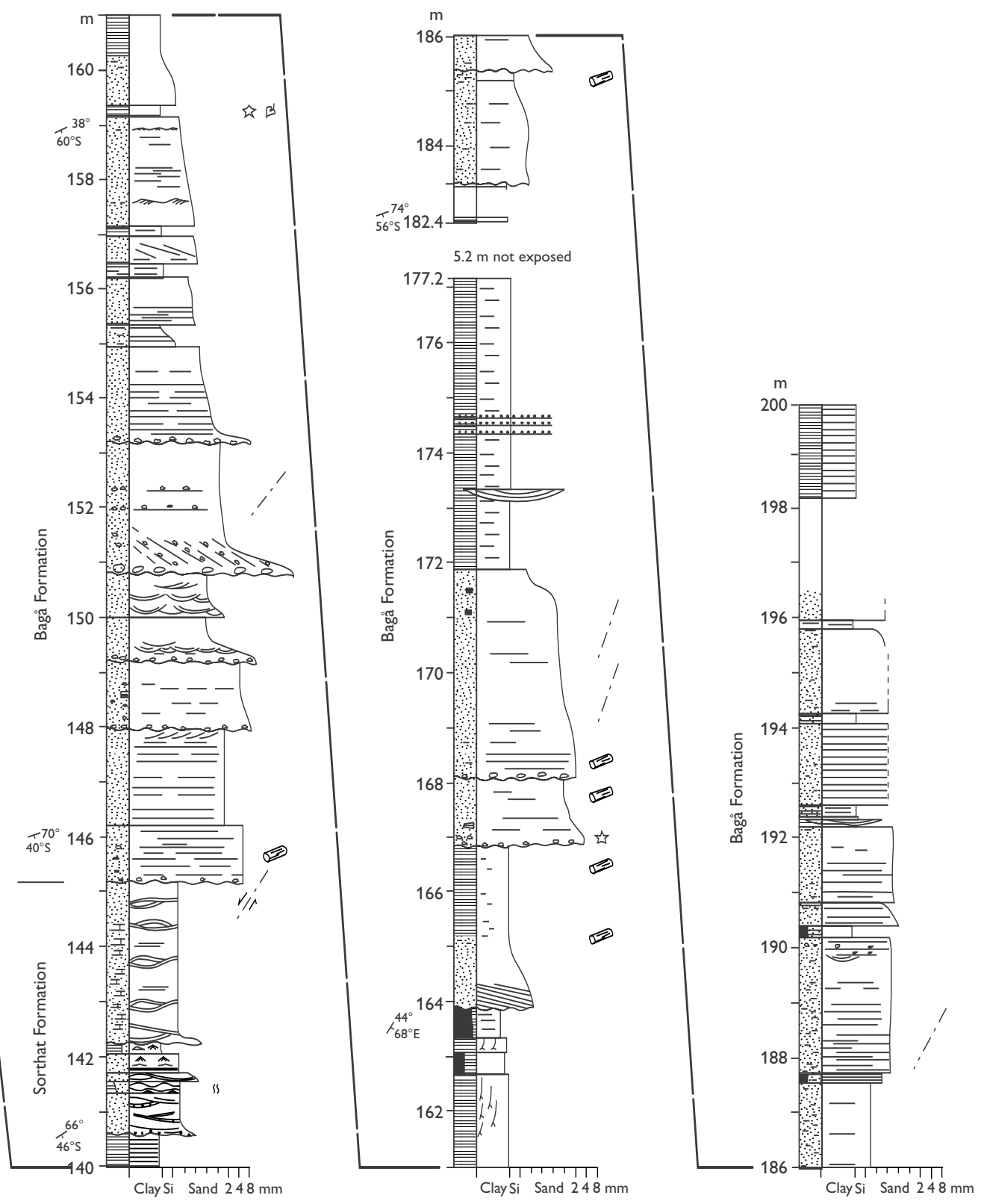
by non-marine palynomorphs. This upper $c .40 \mathrm{~m}$ interval is interpreted as having been deposited in lagoons, coastal lakes and fluvial channels with the clean sand at the top probably representing a marine shoreface.

The reference section at Korsodde is also lithologically highly variable (Fig. 8). The lower c. $93 \mathrm{~m}$ thick unit consists of medium- to coarse-grained, pebbly, cross-bedded and parallel-laminated sand units, up to $6 \mathrm{~m}$ thick. Thin, fine-grained and cross-laminated sand beds occur. The sand is locally almost black due to abundant organic debris. Interbedded with the sand are laminated to almost homogeneous clay beds and fining-upwards heteroliths overlain by laminated dark clay and coaly beds with rootlets. Brackish palynomorphs are present. This part of the section is interpreted to have been deposited in fluvial channels, coastal lakes and lagoons. Above a pronounced erosion surface (Fig. 8, $105.5 \mathrm{~m}$ ) is a fining-upwards unit, c. $19 \mathrm{~m}$ thick, of cross-bedded, coarse- to fine-grained sand overlain by heteroliths and clays capped by a coal seam. Some cross-beds show tidal structures such as reactivation surfaces, bundles and mud-drapes that yield brackish-marine dinoflagellates. Small burrows are also common. Larger burrows, including Diplocraterion isp., occur in the wavy to flaser bedded heteroliths. The unit is interpreted as the fill of an estuarine channel. It is overlain by bioturbated heteroliths with dinoflagellates and burrows of Diplocraterion isp., Teichichnus isp., Skolithos isp. and Planolites isp. Well-sorted, fine-grained sand beds with wave-ripples and swaley cross-stratification also occur. These inferred lagoonal deposits are followed by fluvial sands and lacustrine clays. The uppermost part of the formation in the Korsodde section consists of very fine- to fine-grained, swaley crossstratified and parallel-laminated yellowish-brown sands and sandstones with thin bioturbated and wave-rippled heterolithic beds deposited in the shoreface to offshore transition zone (Koppelhus \& Nielsen 1994). The coals of the Levka-1 and Korsodde sections were primarily formed in anoxic, water-saturated inter-channel environments on a coastal plain (Petersen et al. 2003, this volume).

Log characteristics. The gamma-ray log shows a very variable pattern reflecting the interbedded sands, heteroliths, muds and coals (Fig. 7). Both fining-upwards and coarsening-upwards trends are represented, as testified by gamma log values that increase and decrease upwards, respectively.
Lower boundary. The lower boundary is defined at the change from dark green (unweathered), yellow to indurated brownish (weathered) limonitic marine sandstones of the Hasle Formation to unconsolidated light greyish fluvial sands, lacustrine grey to dark grey clays, and coals (Figs 7, 8). In the type section, the boundary is marked by a change from laminated and cross-bedded, medium- to coarse-grained beach sand of the uppermost Hasle Formation to coal-bearing sand and clay with roots. In the Korsodde reference section, the boundary with the Hasle Formation occurs within a non-exposed interval of $c .8 .4 \mathrm{~m}$, covered by a concrete construction.

Distribution and thickness. The formation occurs in the Rønne-Hasle Fault block, where it is up to $200 \mathrm{~m}$ thick. The formation is also present offshore in the Rønne Graben, as indicated by seismic data and the Stina-1 well (see Fig. 31; Hamann 1994; Nielsen 1995).

Age. Gry (1969) proposed a Middle Jurassic age for the Sorthat, Levka and Bagå beds based on the megaspore content. However, a reassessment of the megaspores revealed the possible presence of Toarcian-Aalenian strata (Koppelhus \& Batten 1992). Based on the recognition of several dinoflagellate assemblages supported by spores and pollen, Koppelhus \& Nielsen (1994) proposed that the age of the Sorthat Formation is Late Pliensbachian - Toarcian, possibly extending up into the Early Aalenian.

\section{Bagå Formation}

revised formation

History. The Bagå Formation was defined by Gravesen et al. (1982) to include the coal-bearing clays and sands in the Rønne-Hasle Fault Block traditionally named the Levka, Sorthat and Bagå beds (reviewed by Gry 1969). The coal-bearing strata at Korsodde and Onsbæk were also included in the Bagå Formation. As discussed above (Sorthat Formation), the Bagå Formation as revised here

\section{Facing page:}

Fig. 9. Hasle Klinkerfabrik clay pit, type section of the Bagå Formation; re-measured by Koppelhus \& Nielsen (1994) to cover the full exposure. Modified from Koppelhus \& Nielsen (1994); for legend, see Fig. 5. 
Hasle Klinkerfabrik clay pit

Type section: Bagå Formation

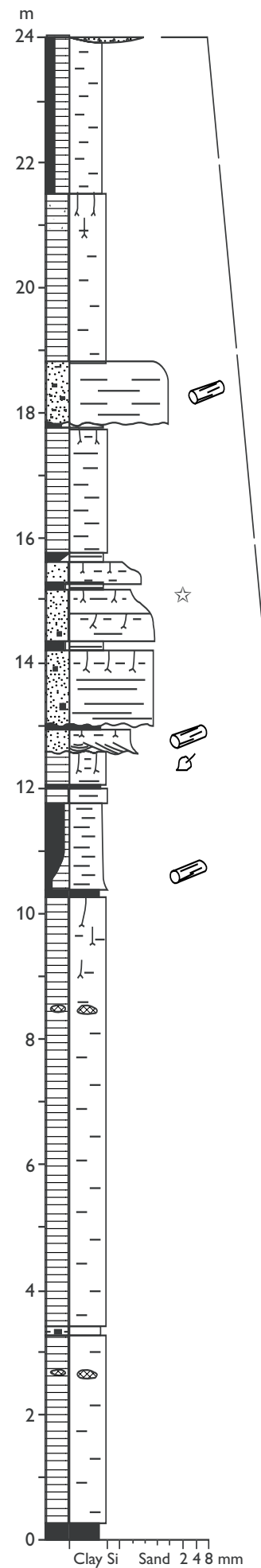

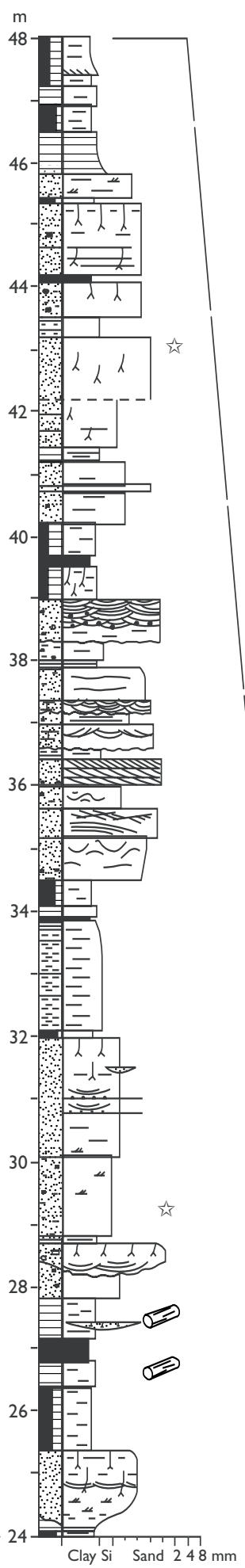

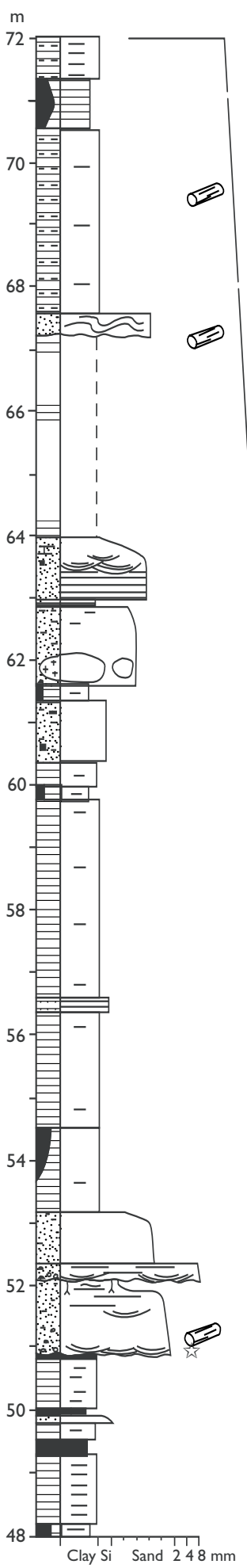

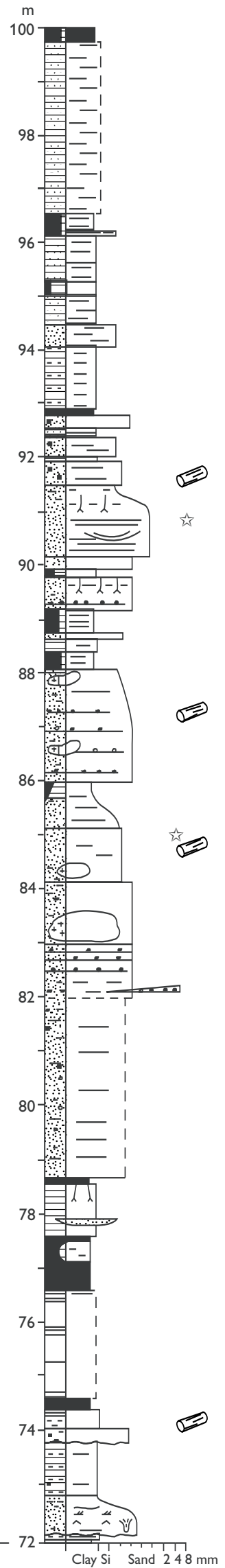


is adopted in a restricted sense to only include the Middle Jurassic Bagå beds of Gry (1969).

Type section. The succession exposed in the Hasle Klinkerfabrik clay pit, immediately south of the Bagå stream, is selected as the type section in accordance with Gravesen et al. (1982), who presented $23 \mathrm{~m}$ of section. The exposed section has been re-measured to present the full section of the pit (Fig. 9).

Reference section. The upper c. $65 \mathrm{~m}$ of the section exposed at Korsodde is proposed as a new reference section (Fig. 8), as the former reference section used by Gravesen et al. (1982, fig. 24) is now referred to the Sorthat Formation.

Lithology and environment. The Bagå Formation includes thick laminated to homogeneous, grey clay units, up to $10 \mathrm{~m}$ thick, dark to black coaly clays with rootlets and coal beds, up to $2.5 \mathrm{~m}$ thick, and medium- to finegrained, cross-bedded or poorly laminated sand beds forming units up to $5.5 \mathrm{~m}$ thick. Poorly sorted, muddy and pebbly sand beds, locally with boulders of weathered granite, occur in the upper part (Fig. 9). The lower part of the reference section at Korsodde comprises poorly parallel-stratified, coarse- to very coarse-grained pebbly sand with boulders of Cambrian quartzites and Lower Palaeozoic kaolinised mudstones (Fig. 8). The middle part comprises laminated grey clay and dark highly carbonaceous clay. The upper part consists of poorly sorted fine- to medium-grained, poorly laminated sand beds, $1.5-3.0 \mathrm{~m}$ thick, interbedded with muddy and carbonaceous sand. Deposition took place in lakes and swamps, small crevasse channels and lacustrine deltas, and fluvial channels (Gravesen et al. 1982; Koppelhus \& Nielsen 1994; Nielsen 1995). The coaly clays and coal beds were primarily deposited in open freshwater mires subjected to some siliciclastic deposition. Coal beds in the upper part of the formation were deposited on an alluvial fan with a fluctuating watertable.

Boundaries. The lower boundary is not exposed in the Sorthat area and was not encountered in the cored wells. In the Korsodde reference section, the lower boundary is defined at a significant pebble-strewn erosion surface separating swaley to hummocky crossstratified, weakly cemented, yellowish brown, finegrained shoreface sandstones of the upper Sorthat Formation from overlying coarse-grained, pebbly, light grey to white, largely unconsolidated fluvial sands with pebbles and boulders (Fig. 8, $145.2 \mathrm{~m}$ ).
Onshore, the upper boundary is an erosion surface defining the present-day land surface or the base of the Quaternary. The Korsodde section is faulted against the Upper Cretaceous Bavnodde Greensand.

Distribution and thickness. The Bagå Formation is present in the Rønne-Hasle Fault Block, where it is estimated to be more than $190 \mathrm{~m}$ thick (Gry 1969), and is also present offshore in the Rønne Graben with a similar thickness as indicated by seismic data (Jensen \& Hamann 1989; Hamann 1994).

Age. The Bagå beds were referred to the Middle Jurassic by Gry (1969) based on megaspores. Hoelstad (1985) referred the Bagå beds as exposed in the Hasle Klinkerfabrik clay pit to the uppermost Toarcian Aalenian and Bajocian-Bathonian. However, the palynoflora used by Hoelstad (1985) for the identification of the uppermost Toarcian - Aalenian in the Bagå beds appear to have a longer range than originally supposed (T. Hoelstad, personal communication 1994). Based on the content of spores and pollen in the Bagå beds in the Hasle Klinkerfabrik clay pit and the reference section from Korsodde, the age of the re-defined Bagå Formation is Middle Jurassic, probably including the Late Aalenian, Bajocian and Bathonian (Koppelhus \& Nielsen 1994).

\section{Danish Basin}

The Upper Triassic - lowermost Cretaceous succession of the Danish Basin is referred to six formations, the Gassum, Fjerritslev, Haldager Sand, Flyvbjerg, Børglum and Frederikshavn Formations (Fig. 2). New reference sections are proposed here for the Gassum and Fjerritslev Formations.

\section{Gassum Formation}

History. The Gassum Formation was defined by Larsen (1966), and redefined by Bertelsen (1978).

Type section. The Gassum-1 well, 5406-4980 ft b. KB, 1590-1460 m b. MSL, in the Danish Basin (Larsen 1966; Bertelsen 1978).

Reference section. The Hyllebjerg-1 well, 2751-2582 m b. KB, 2723-2554 $\mathrm{m}$ b. MSL, drilled centrally in the Danish Basin is here selected as a reference section in 
order to present a modern log suite as the petrophysical logs available from the Gassum- 1 well are of poor quality (Fig. 10).

Lithology and environment. The formation consists predominantly of light grey to whitish fine- to mediumgrained, and in places coarse-grained sandstones, interbedded with grey and greenish grey heteroliths, dark-coloured claystones and a few thin coal beds. An overall deltaic origin was suggested by Larsen (1966) and Bertelsen (1978); the sandstones are both of fluvial channel and marine shoreface origin, however, and occur as widespread sheets that represent several progradational events. The intervening claystones are dominantly marine with some of lacustrine and lagoonal origin in the south-eastern and north-eastern parts of the basin (Nielsen et al. 1989; Hamberg 1994; Hamberg \& Nielsen 2000; Nielsen 2003, this volume).

Log characteristics. The formation is characterised by changes between high and low gamma-ray values and rather constant and high sonic readings, reflecting interbedded sandstones and claystones. Thin intervals with low sonic values probably reflect coal beds.

The gamma-ray and SP logs show different styles in different locations within the Danish Basin. In the central area of the basin, the lower part of the formation includes two intervals showing low, decreasing-upwards gamma-ray values (Fig. 10), while more blocky motifs occur in the northern part of the basin; in the south, the gamma-ray log shows increasing-upwards trends. Above is a thin interval with high gamma-ray values, succeeded by an overall decreasing-upwards trend, but interrupted by gamma spikes attaining high values. The top of the formation is commonly characterised by a blocky gamma-ray low. To the north and north-west, the upper levels of the formation are characterised by rather high gamma-ray values, decreasing slightly upwards.

Lower boundary. Decreasing-upwards gamma-ray values and increasing sonic values reflect the transition from the underlying Vinding Formation to the Gassum Formation. The boundary is located at the base of the lowermost significant sandstone bed within this transition. The Skagerrak Formation - Gassum Formation boundary, in the northern and eastern parts of the basin, is similarly defined at the base of the first significant sandstone bed overlying claystones of the uppermost Skagerrak Formation.

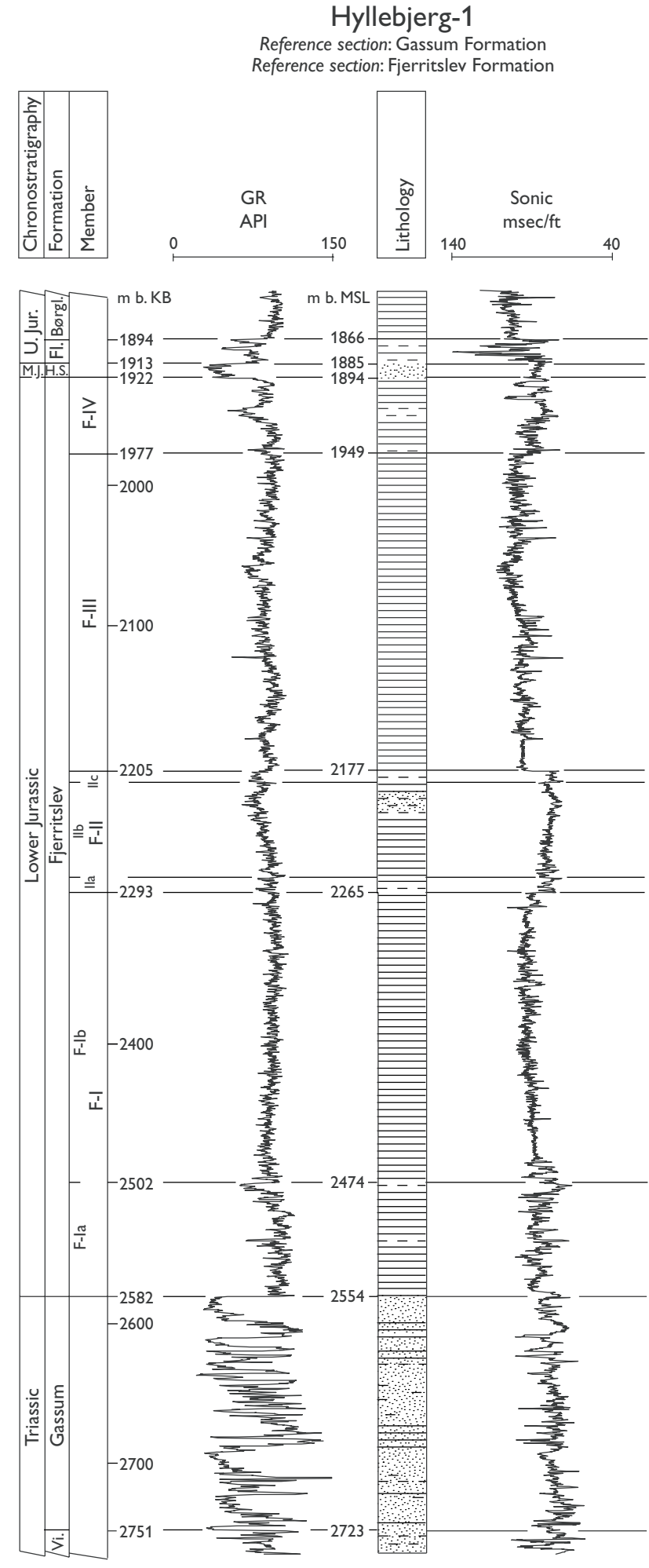

Fig. 10. Hyllebjerg-1 well, located in the Danish Basin; new reference section for the Gassum Formation, 2723-2554 m b. MSL, and the Fjerritslev Formation, 2554-1894 m b. MSL. Børgl., Børglum; Fl., Flyvbjerg; H.S., Haldager Sand; Vi., Vinding; M.J., Middle Jurassic; U. Jur., Upper Jurassic. Modified from Michelsen (1989a); for legend, see Fig. 5. 
Distribution and thickness. The formation is present in the Danish Basin and locally in the North German Basin. Maximum thicknesses of more than $300 \mathrm{~m}$ occur in the Sorgenfrei-Tornquist Zone.

Age. Late Norian - Rhaetian over most of the basin, younging towards the north-eastern margin, where the formation is of Hettangian - Early Sinemurian age (Michelsen 1975; Bertelsen 1978, 1980; L.H. Nielsen, L. Hamberg and E.B. Koppelhus in: Nielsen 1995).

Remarks. The formation was subdivided informally into three members by Bertelsen (1978), but new well sections suggest that they are not consistently identifiable.

\section{Fjerritslev Formation}

History. The Fjerritslev Formation was defined by Larsen (1966), and amended by Michelsen (1978a).

Type section. The Fjerritslev-2 well, 2233-1322 m b. KB, 2225-1314 m b. MSL, in the Danish Basin (Fig. 11; Larsen 1966; Michelsen 1978a).

Reference section. Petrophysical logs are not available from the entire section in the Fjerritslev-2 well, and the section in Hyllebjerg-1, 2582-1922 m b. KB, 2554-1894 $\mathrm{m}$ b. MSL, is selected as reference section (Fig. 10). This section was described in detail by Michelsen (1989a).

Lithology and environment. The formation consists of a relatively uniform succession of marine, dark grey to black, slightly calcareous claystones, with a varying content of silt and siltstone laminae. Clay-ironstone concretions are common. Siltstones and fine-grained sandstones form a minor proportion of the succession, being most common on the Skagerrak-Kattegat Platform. Deposition took place in a deep offshore to lower shoreface environment (Michelsen 1975, 1978a; Pedersen 1985; Nielsen 2003, this volume).

Log characteristics. The formation is characterised by rather uniform high gamma-ray values, but subordinate lows are present in three of the five lithostratigraphic units described below (Fig. 10; F-Ia, F-Ib, F-II, F-III, F-IV). The log-motifs of the SP curve closely conform to those of the gamma-ray curve (Fig. 11). The sonic and resistivity values are higher in the three units characterised by gamma-ray lows than in the two intervening units (Figs 10, 11).

Lower boundary. In the Danish Basin, the lower boundary is defined at an abrupt change from low to high gamma-ray values, indicating the shift from the sandstones of the Gassum Formation to the claystones of the Fjerritslev Formation (Fig. 10). In some cases, the boundary is characterised by a more gradual transition from low to high gamma-ray values (see Figs 30, 32).

Distribution and thickness. The formation is present over most of the Danish Basin, in the southern part of the Danish Central Graben, and locally within the Norwegian part of the Norwegian-Danish Basin. The thickness is very variable due to mid-Jurassic erosion. The maximum thickness recorded in well sections is 911 $\mathrm{m}$ in the type section. Seismic data indicate a thickness of more than $1000 \mathrm{~m}$ in the Fjerritslev Trough.

Age. Mainly Early Jurassic (Michelsen 1975, 1989a), although locally extending down into the Late Rhaetian (Dybkjær 1991) and up into the Early Aalenian (Michelsen \& Nielsen 1991; Nielsen 1992, 2003, this volume; Poulsen 1996). The lower boundary of the formation is diachronous, younging towards the northeast where it is of Early Sinemurian age. The upper boundary is erosional except for within the SorgenfreiTornquist Zone.

Subdivision. Michelsen (1978a, 1989a) subdivided the formation into four informal members (F-I - F-IV), the lowermost of which can be subdivided into two units, F-Ia and F-Ib, over much of the Danish Basin.

The Upper Rhaetian - lowermost Sinemurian F-Ia unit consists of uniform claystones and claystones interbedded with siltstones, which are locally carbonatecemented. The unit is characterised by decreasingupwards gamma-ray values and increasing sonic values. The lower boundary coincides with the lower boundary of the formation. The unit is recognised in most wells in the Danish Basin and in a few wells in the Danish Central Graben. The Sinemurian - Lower Pliensbachian

\section{Facing page:}

Fig. 11. Fjerritslev-2 well, located in the Sorgenfrei-Tornquist Zone; type section for the Fjerritslev Formation, 2225-1314 m b. MSL. M. Jur., Middle Jurassic. Modified from Michelsen (1978a); for legend, see Fig. 5. 
Fjerritslev-2

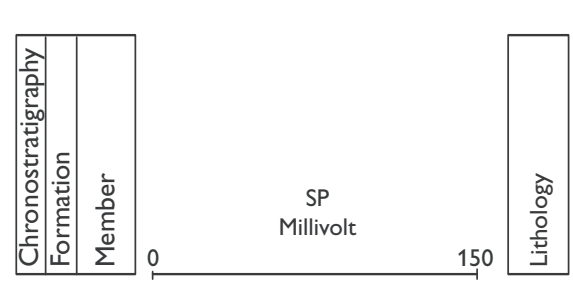

Type section: Fjerritslev Formation

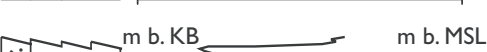

MSL
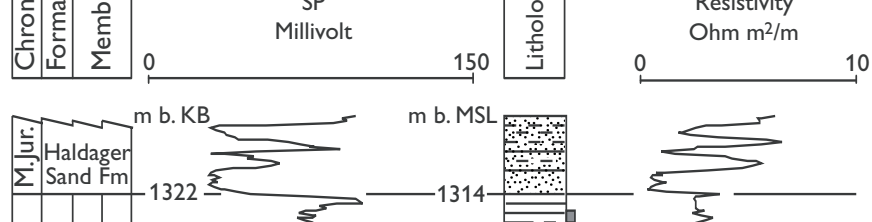

\begin{tabular}{l|l|l}
2 & \multicolumn{1}{|c}{1322} & \\
& &
\end{tabular}
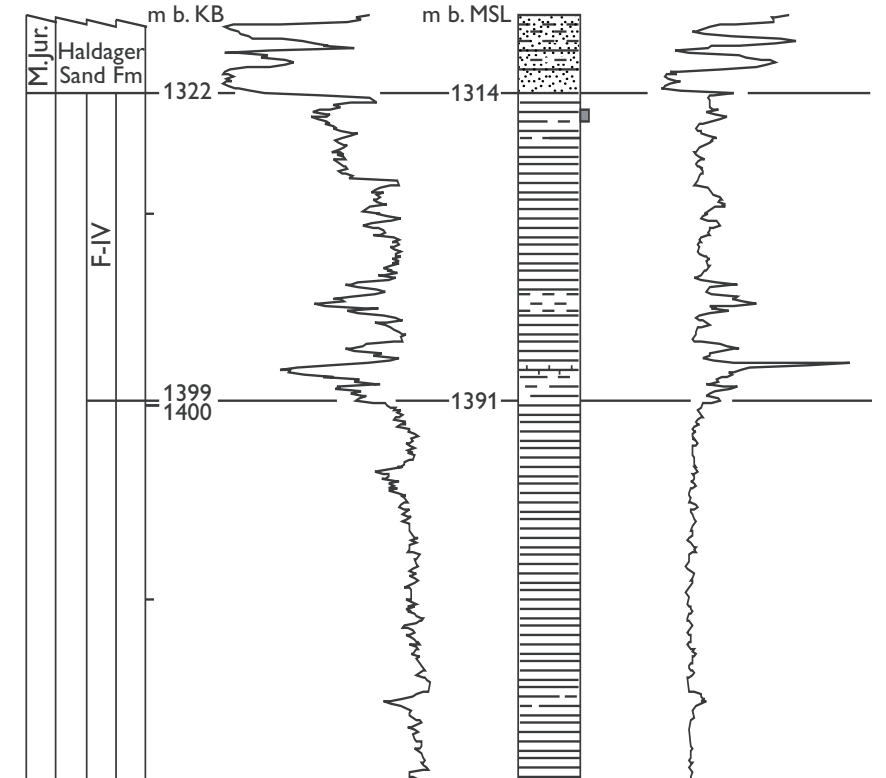

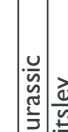

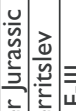

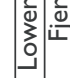
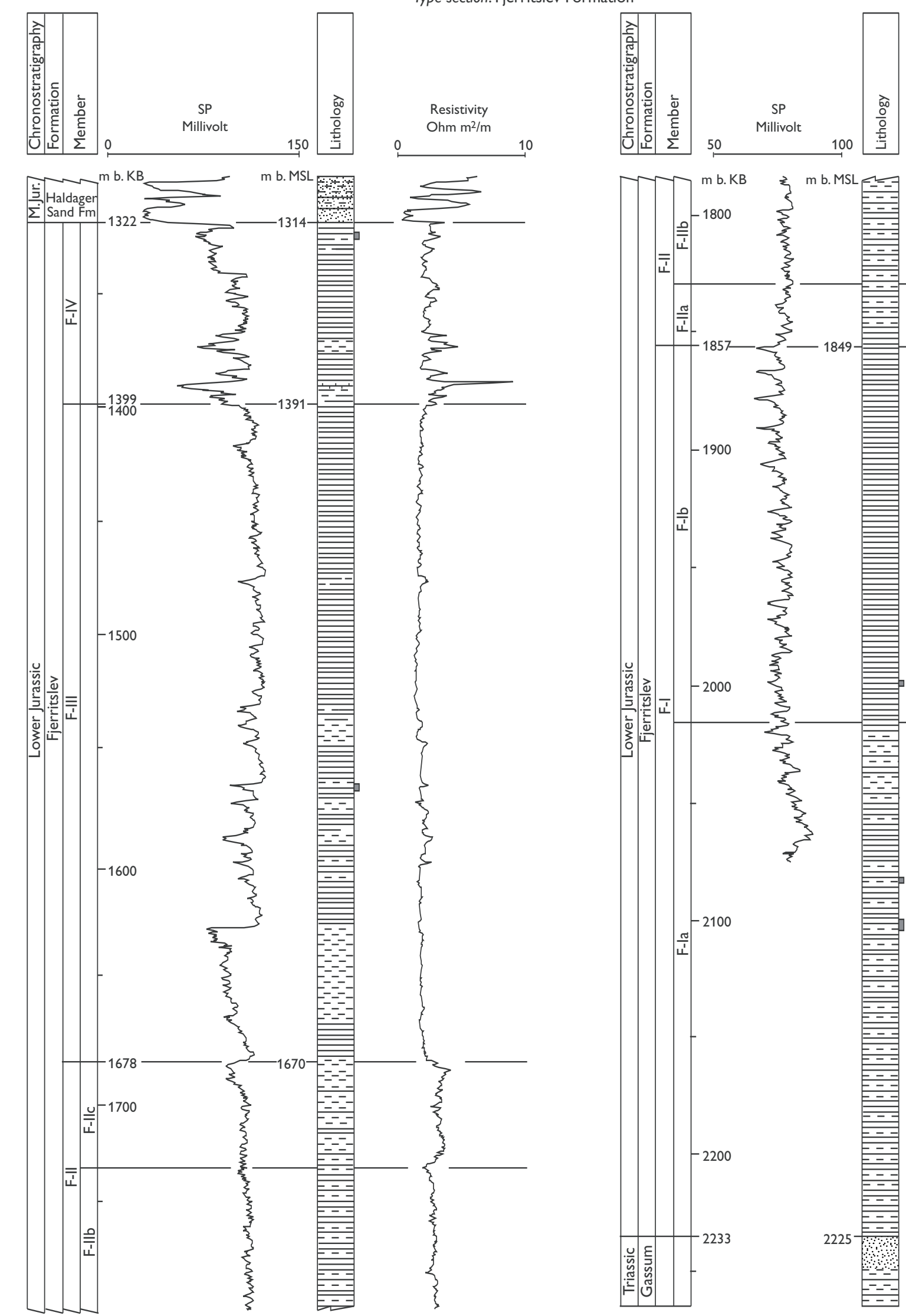

Resistivity Ohm m²/m

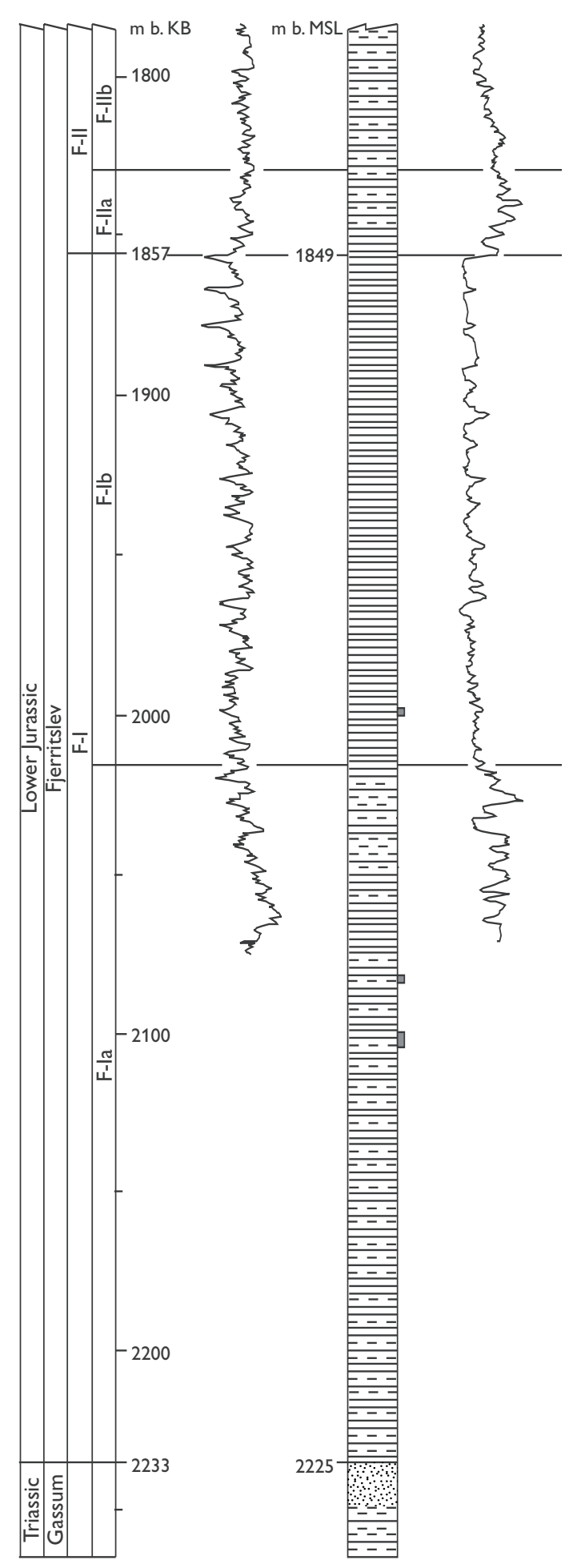


F-Ib unit is dominated by uniform claystones showing constantly high gamma-ray values. The lower boundary is characterised by a distinct log-break to higher gamma-ray values and lower sonic values. The unit is recognised in most wells in the Danish Basin and also in the Danish Central Graben.

\section{Haldager-1}

Type section: Haldager Sand Formation Reference section: Flyvbjerg Formation
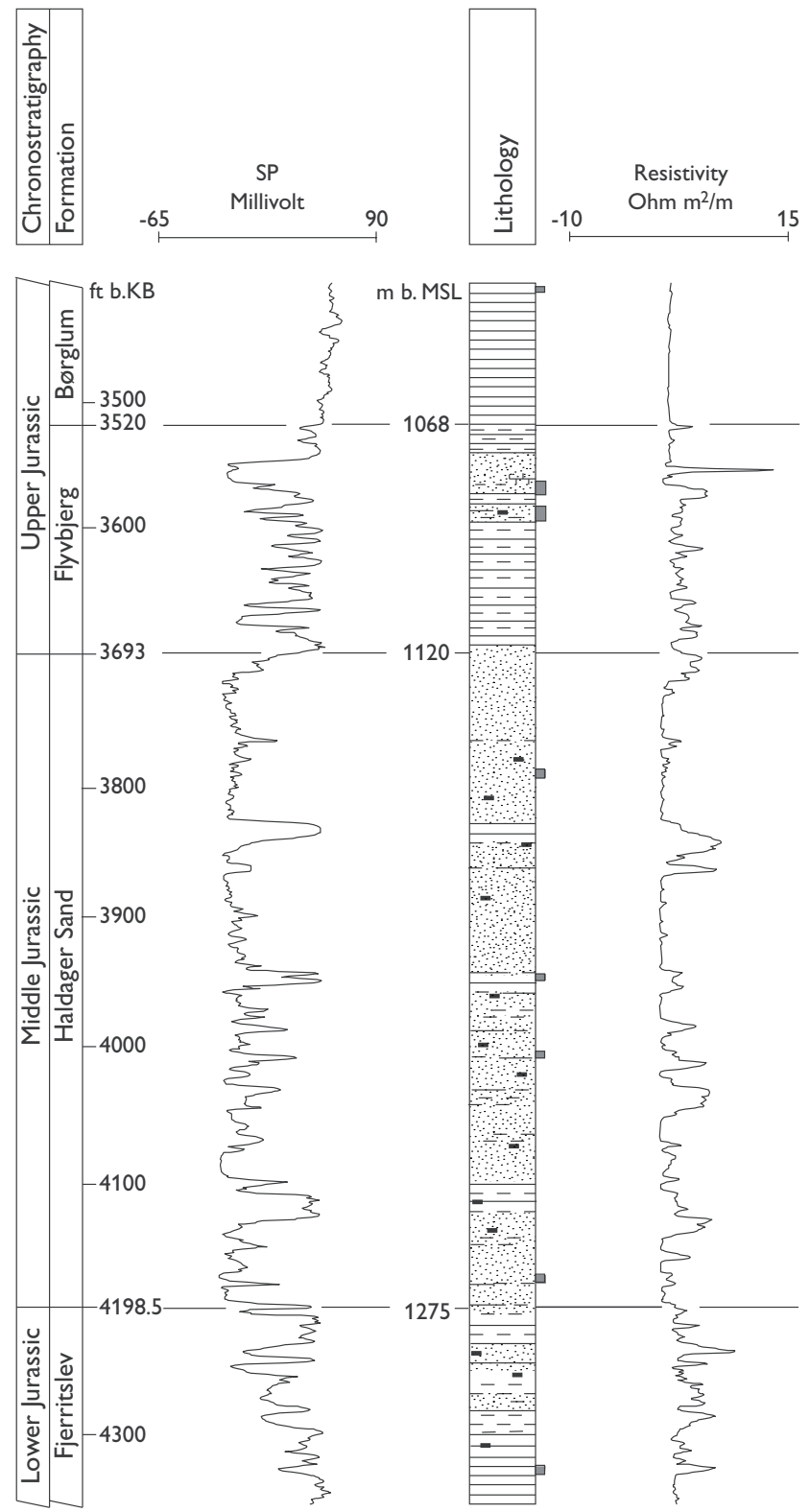

Fig. 12. Haldager-1 well, located in the Sorgenfrei-Tornquist Zone; type section for the Haldager Sand Formation, 1275-1120 m b. MSL; reference section for the Flyvbjerg Formation, 1120-1068 m b. MSL. Modified from Michelsen (1978a); for legend, see Fig. 5.
The Lower-Upper Pliensbachian F-II member differs from the deposits below and above in that it consists of faintly laminated claystones interbedded with siltstones and sandstones. Towards the north-east, on the Skagerrak-Kattegat Platform, the member is dominated by fine-grained sandstones. The member was subdivided into three units (F-IIa to F-IIc) by Michelsen (1978a, 1989a) in a few wells located in the central part of the Danish Basin. The member typically shows decreasing-upwards gamma-ray and increasing sonic values, with a distinct log-break on the sonic curve at the base of the member. The member varies laterally in thickness, but is recognised in most wells in the Danish Basin.

The Upper Pliensbachian - Lower Toarcian F-III member is dominated by uniform claystones, which in places are slightly silty. Consistently high gamma-ray values typify the member, and a distinct shift to lower sonic values defines the lower boundary. The member is recognised in most wells in the Danish Basin, except for the southernmost part.

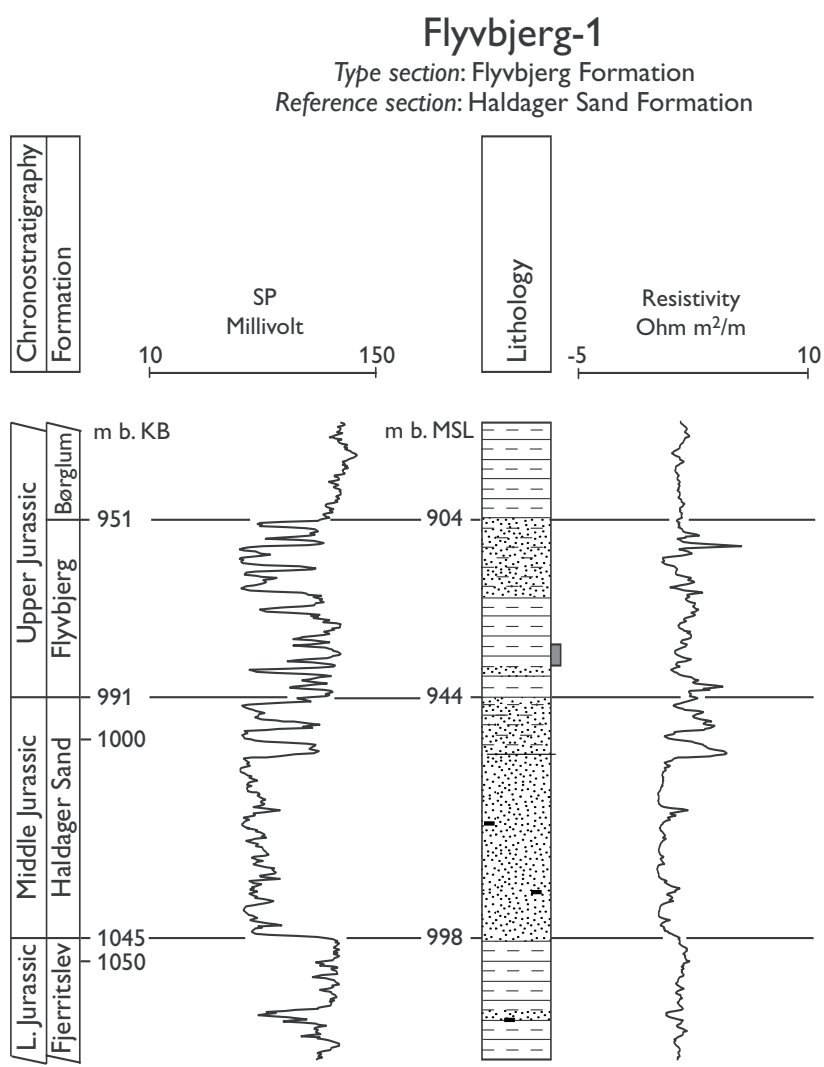

Fig. 13. Flyvbjerg-1 well, located in the Sorgenfrei-Tornquist Zone; type section for the Flyvbjerg Formation, 944-904 m b. MSL; reference section for the Haldager Sand Formation, 998-944 m b. MSL. Modified from Michelsen (1978a); for legend, see Fig. 5. 
The Upper Toarcian - Lower Aalenian F-IV member consists of uniform claystones with varying silt content, interbedded with sandstones that are locally carbonate-cemented. The proportion of sandstone, locally with organic debris and coal fragments, increases in the Fjerritslev Trough and on the Skagerrak-Kattegat Platform. The member is characterised by a distinct shift to higher sonic values at the base. The presence of sandstone intercalations is identified by gamma-ray lows, and carbonate-cemented levels are reflected by high sonic peaks. The top of the member coincides with the top of the formation. The member is recognised in the north-eastern part of the Danish Basin, the Sorgenfrei-Tornquist Zone and the Skagerrak-Kattegat Platform.

\section{Haldager Sand Formation}

History. The Haldager Formation was defined by Larsen (1966), and amended by Michelsen (1978a) who subdivided the formation into two members, the lower of which was defined as the Haldager Sand Member. The member was later given the rank of formation, and the Haldager Formation was abandoned (Michelsen 1989a).

Type section. The Haldager-1 well, 4198.5-3693 ft b. $\mathrm{KB}, 1275-1120 \mathrm{~m}$ b. MSL in the Sorgenfrei-Tornquist Zone is defined as the type section (Fig. 12; Larsen 1966; Michelsen 1978a).

Reference section. The Flyvbjerg-1 well, 1045-991 m b. KB, 998-944 m b. MSL in the Sorgenfrei-Tornquist Zone (Fig. 13; Michelsen 1978a).

Lithology and environment. The formation consists of thick beds of light olive-grey, fine- to coarse-grained occasionally pebbly sandstones and siltstones interbedded with claystones and thin coal beds. The southwestern part of the basin and the Skagerrak-Kattegat Platform is dominated by sandstones deposited in braided rivers and lacustrine mudstones (Koch 1983). Shallow marine sandstones, estuarine sandstones and mudstones, and marine mudstones occur in the Sorgenfrei-Tornquist Zone (Nielsen 2003, this volume).

Log characteristics. The dominance of thick sandstones (low gamma-ray values) interbedded with thin claystones (high gamma-ray spikes) yields a characteristic blocky pattern which is replicated on the SP and resistivity curves (Figs 12, 13).
Lower boundary. The lower boundary is defined at an abrupt change from high to low gamma-ray values and the corresponding shift of the SP log, indicating the abrupt change from the claystones of the Fjerritslev Formation to the sandstones of the Haldager Sand Formation (Figs 12, 13). A regional unconformity separates the two formations.

Distribution and thickness. The formation is distributed in the central and northern part of the Danish Basin,

\section{Frederikshavn-1 \\ Type section: Frederikshavn Formation \\ Reference section: Flyvbjerg Formation \\ Børglum Formation}
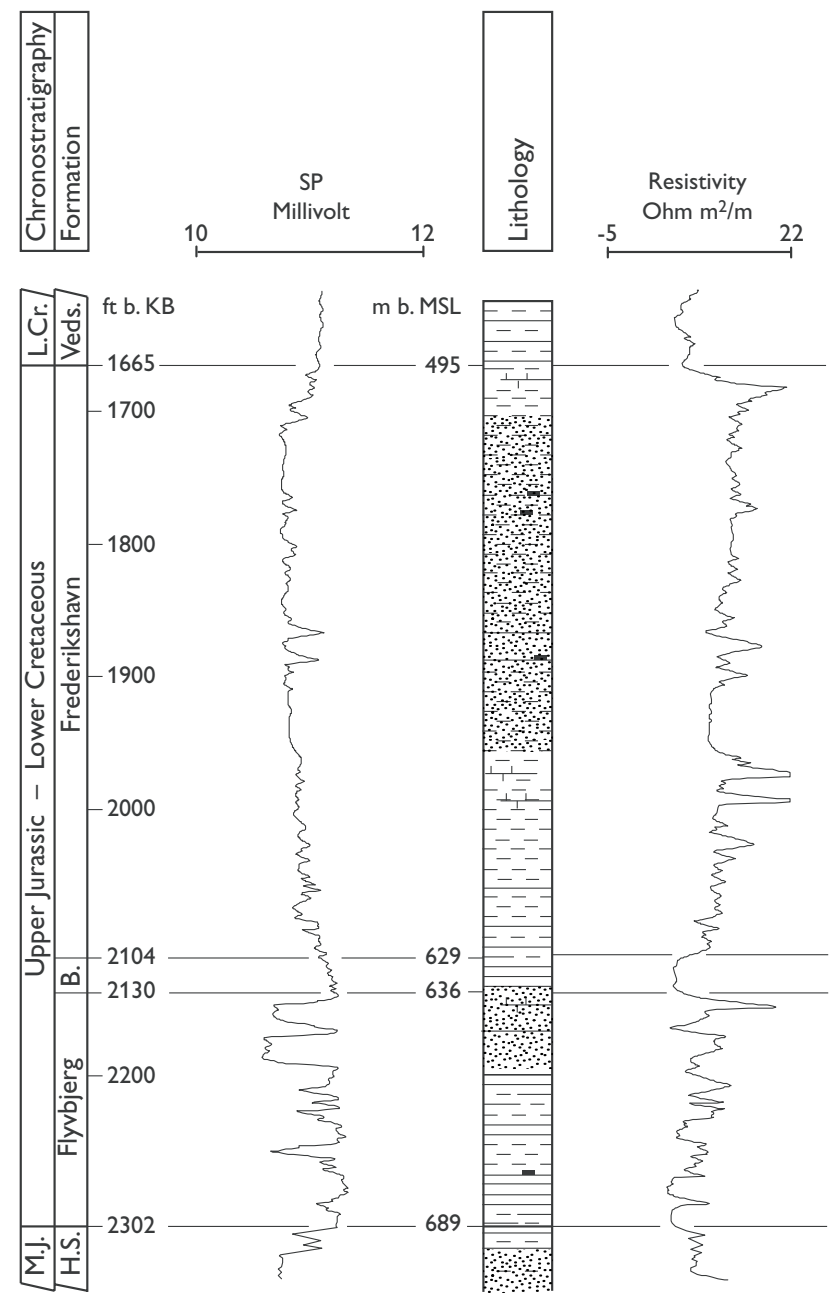

Fig. 14. Frederikshavn-1 well, located on the Skagerrak-Kattegat Platform; type section for the Frederikshavn Formation, 629-495 m b. MSL; reference section of the Flyvbjerg Formation, 689-636 $\mathrm{m}$ b. MSL and Børglum Formation, 636-629 m b. MSL. B., Børglum; Veds., Vedsted; H.S., Haldager Sand; M.J., Middle Jurassic; L.Cr., Lower Cretaceous. Modified from Michelsen (1978a); for legend, see Fig. 5. 
in the Sorgenfrei-Tornquist Zone and on the SkagerrakKattegat Platform. Maximum thicknesses of more than $150 \mathrm{~m}$ are found in the Sorgenfrei-Tornquist Zone (including the type section), and a significant thinning is seen south-west and north-east of this zone.

Age. The formation is generally referred to the BajocianBathonian although the age is poorly constrained; in the Sorgenfrei-Tornquist Zone, the formation is probably of Aalenian-Callovian age although may extend into the Early Oxfordian (Michelsen \& Nielsen 1991; Poulsen 1996; see discussion in Nielsen 2003, this volume).

\section{Flyvbjerg Formation}

History. The Haldager Formation was defined by Larsen (1966). Michelsen (1978a) amended and subdivided the formation into two members, the upper of which was defined as the Flyvbjerg Member. The member was later elevated to formation rank, and the Haldager Formation was abandoned (Michelsen 1989a).

Type section. The Flyvbjerg-1 well, 991-951 m b. KB, 944-904 m b. MSL, in the Sorgenfrei-Tornquist Zone (Fig. 13; Michelsen 1978a).

Reference sections. The Haldager-1 well in the SorgenfreiTornquist Zone, 3693-3520 ft b. KB, 1120-1068 m b. MSL, and the Frederikshavn-1 well on the SkagerrakKattegat Platform, 2302-2130 ft b. KB, 689-636 m b. MSL (Figs 12, 14; Michelsen 1978a).

Lithology and environment. The basal part of the formation consists of light olive-grey sandstones and siltstones with traces of coals and locally abundant roots. It is overlain by olive-grey and greyish to olive-black claystones, interbedded with fossiliferous, calcareous sandstones. The upper part of the formation consists of fine-grained sandstones, which are highly calcareous and contain glauconite and traces of pyrite. The sediments were mainly deposited in a shallow marine to offshore marine environment.

Log characteristics. The formation is characterised by relatively high gamma-ray values and corresponding SP values at the base, decreasing to low values at the top, and by variable sonic velocities. The overall decrease upwards in gamma-ray values is interrupted by thin intervals with low values, reflecting interbedded claystones and thin sandstones. In most wells, a thick sandstone bed represented by a blocky gamma-ray low and a corresponding SP value occurs at the top of the formation.

Lower boundary. The lower boundary is defined at an abrupt change from low to higher gamma-ray values and a corresponding shift of the SP curve, indicating the change from the sandstones of the Haldager Sand Formation to the more fine-grained clay-rich deposits lowermost in the Flyvbjerg Formation (Fig. 13). In some wells, a more gradual increase in gamma-ray values characterises the uppermost Haldager Sand Formation, while the lower part of the Flyvbjerg Formation shows a few gamma-ray lows representing thin sandstone beds (Haldager-1 and Børglum-1; Fig. 12, see also Fig. 30).

Distribution and thickness. The formation occurs in the central part and along the northern margin of the Danish Basin, in the Sorgenfrei-Tornquist Zone and on the Skagerrak-Kattegat Platform forming a north-eastwards thickening wedge. Maximum thicknesses of over $50 \mathrm{~m}$ are found in the Sorgenfrei-Tornquist Zone and on the Skagerrak-Kattegat Platform.

Age. Late Early or early Middle Oxfordian to Late Kimmeridgian. Both the base and top of the Flyvbjerg Formation are diachronous, younging towards the northeastern margin of the Danish Basin (Poulsen 1996).

\section{Børglum Formation}

History. The Børglum Formation was defined by Larsen (1966) but was subsequently demoted to the Børglum Member of the Bream Formation by Michelsen (1978a). The Bream Formation was abandoned by Vollset \& Doré (1984), and the Børglum Member was later restored to the rank of formation (Michelsen 1989a).

Type section. The Børglum-1 well in the SorgenfreiTornquist Zone, 3323-3213 ft b. KB, 990-957 m b. MSL (Fig. 15; Larsen 1966; Michelsen 1978a).

Reference section. The Frederikshavn-1 well on the Skagerrak-Kattegat Platform, 2130-2104 ft b. KB, 636-629 m b. MSL (Fig. 14; Michelsen 1978a).

Lithology and environment. The formation consists of a relatively uniform succession of olive to blackish grey, slightly calcareous, homogeneous claystones with varying contents of silt, mica and pyrite. The sediments were mainly deposited in an offshore marine environment. 
Log characteristics. The formation is characterised by rather uniform high gamma-ray values and low sonic velocities. The sonic curve is rather constant in the lower part of the formation, but becomes serrated in the upper part.

Lower boundary. The lower boundary is located at the top of the thick sandstone beds uppermost in the Flyvbjerg Formation (Fig. 14) or slightly above (Fig. 15). The boundary is defined by an abrupt shift from high resistivities and high sonic velocities to lower resistivities and sonic velocities above the boundary (see Fig. 30).

Distribution and thickness. The formation is distributed over most of the Danish Basin. Maximum thicknesses, up to $300 \mathrm{~m}$, are found in wells located close to the Fjerritslev Fault (e.g. J-1, see Fig. 32); a pronounced thinning occurs towards the north-east, south and southwest.

Age. Earliest Early Kimmeridgian - Early Volgian over most of the basin (Poulsen 1996). The base and top of the formation are diachronous; the base youngs towards the north-eastern margin of the basin (Poulsen 1996), and towards the west the upper part of the formation is contemporaneous with the Frederikshavn Formation and extends into the Ryazanian (Michelsen 1989a).

\section{Frederikshavn Formation}

History. The Frederikshavn and Skagen Formations were defined by Larsen (1966) but were subsequently combined and reduced in rank to the Frederikshavn Member of the Bream Formation by Michelsen (1978a). The Bream Formation was abandoned by Vollset \& Doré (1984), and the Frederikshavn Member was subsequently elevated to the rank of formation (Michelsen 1989a).

Type section. The Frederikshavn-1 well, 2104-1665 ft b. KB, 629-495 m b. MSL, on the Skagerrak-Kattegat Platform (Fig. 14; Larsen 1966; Michelsen 1978a).

Reference section. The Børglum-1 well, 3213-2478.5 ft b. KB, $957-733 \mathrm{~m} \mathrm{~b}$. MSL, in the Sorgenfrei-Tornquist Zone (Fig. 15; Michelsen 1978a).

Lithology and environment. The formation consists of siltstones and fine-grained sandstones, greenish grey,

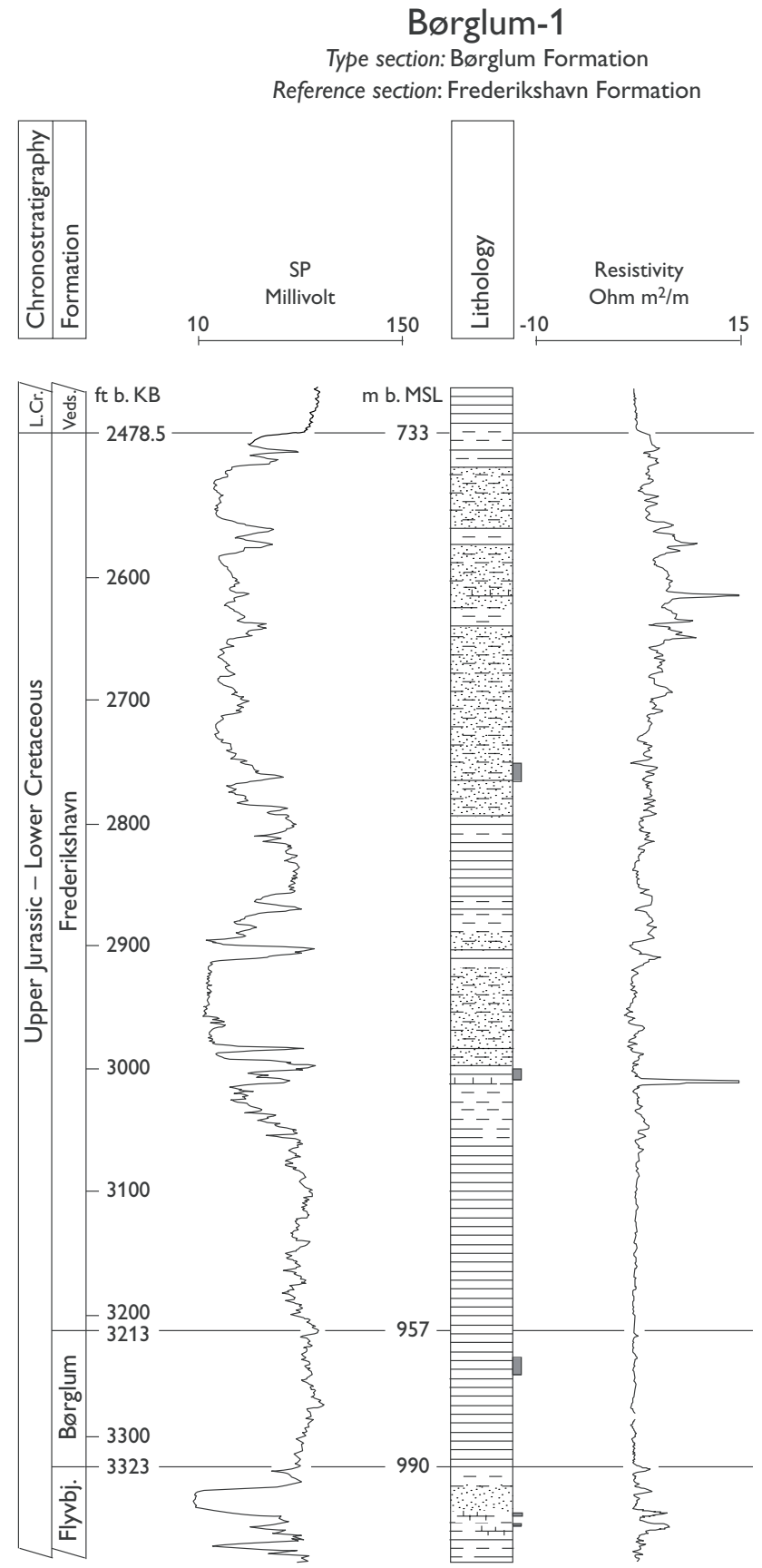

Fig. 15. Børglum-1 well, located in the Sorgenfrei-Tornquist Zone; type section for the Børglum Formation, 957-990 m b. MSL. Flybj., Flyvbjerg; Veds., Vedsted; L.Cr., Lower Cretaceous. Modified from Michelsen (1978a); for legend, see Fig. 5.

light olive-grey and olive-black, slightly calcareous, in places with micro-lignite. The siltstones and sandstones are interbedded with thin silty, greyish black, and calcareous claystones and form $2-3$ generally coarseningupwards units separated by claystone-dominated intervals. Glauconite and fragments of bivalves and 
ammonites are common in the lower and upper parts of the formation (Sorgenfrei \& Buch 1964; Larsen 1966; Birkelund \& Pedersen 1980). In the Sorgenfrei-Tornquist Zone, sandstones are particularly common in the middle part of the formation. Close to the north-eastern basin margin, coal beds a few centimetres thick occur in the upper part of the formation. Deposition mainly took place in a shallow marine to offshore environment. Non-marine conditions prevailed on the SkagerrakKattegat Platform and locally in the Sorgenfrei-Tornquist Zone during deposition of parts of the middle coarsening-upwards unit and the lower part of the upper unit (Larsen 1966; Michelsen 1978a).

Log characteristics. The 2-3 coarsening-upwards successions of siltstones and sandstones are reflected by repeated decreasing-upwards trends on the gamma-ray curve, and corresponding features on the SP curve (Figs 14, 15). The uppermost part of the formation is characterised by a gradual increase in gamma-ray values. The sonic velocities are high and rather constant, except for a slight decrease in values at the two clayey intervals that separate the coarsening-upwards successions (Hyllebjerg-1; see Fig. 30).

Boundaries. The lower boundary is defined by a decrease upwards in gamma-ray values and corresponding features of the SP curve, reflecting the transition from the claystones of the underlying Børglum Formation to the more coarse-grained Frederikshavn Formation. The boundary may be best defined by a minor shift from low to higher sonic velocities (Hyllebjerg-1, see Fig. 30).

The upper boundary with the claystones of the Lower Cretaceous Vedsted Formation is also a gradual transition. An increase upwards in gamma-ray values and a shift to lower sonic velocities characterises the boundary in the central part of the Danish Basin (e.g. Hyllebjerg-1). In the Sorgenfrei-Tornquist Zone, a more abrupt boundary is indicated by the SP and resistivity logs (Figs 14, 15).

Distribution and thickness. The formation occurs in the eastern part of the Danish Basin. Maximum thicknesses of more than $230 \mathrm{~m}$ are found in wells from the Sorgenfrei-Tornquist Zone (e.g. Haldager-1, Terne-1). Relatively thick and coarse-grained successions are also found in the Børglum-1, Frederikshavn-1, Rønde-1 and Horsens-1 wells. The thinner and more fine-grained successions found in the Hyllebjerg-1, Skive-1, Kvols-1, Rødding-1 and Oddesund-1 wells, located in the cen- tral part of the basin, seem to mark the westernmost extent of the Frederikshavn Formation. The succession previously assigned to the formation by Michelsen (1978a) in the Nøvling-1, J-1, F-1 and K-1 wells further to the west is fine-grained, mainly clay-dominated, and is best referred to the Børglum Formation (Michelsen 1989a).

Age. Volgian-Ryazanian. The formation is time-equivalent with the upper part of the Børglum Formation in the central and western parts of the Norwegian-Danish Basin (Michelsen 1989a; Poulsen 1996).

\section{Danish Central Graben}

The Jurassic succession of the Danish Central Graben is referred to seven formations, the Fjerritslev, Bryne, Lulu, Middle Graben, Lola, Heno and Farsund Formations, of which the Bryne Formation is revised and the Lulu Formation is new (Fig. 2). Two new members are defined in the Heno Formation and the informal 'hot unit' in the Farsund Formation is defined as the Bo Member.

\section{Fjerritslev Formation}

History, type and reference sections. The formation was defined from the Danish Basin (Larsen, 1966; Michelsen 1978a) and a full description is given above. Jensen et al. (1986) defined a reference section (O-1 well) in the Danish Central Graben.

Lithology and environment. The formation is dominated by dark grey, slightly calcareous claystones, as seen in the Danish Basin (see above). In contrast to the latter area, however, the lower levels of the formation in the Central Graben are notably more carbonate-rich, with interbeds of calcareous silty claystone and soft marlstone (Jensen et al. 1986).

Log characteristics. Uniform high gamma-ray values and a uniform sonic velocity pattern characterise the formation; a more erratic sonic log in the lower levels reflects the presence of calcite-cemented silty claystones and thin soft marlstone beds.

Lower boundary. In the Danish Central Graben, the formation overlies the Triassic clay-dominated Winterton Formation, which is characterised by very low sonic 
velocities and high gamma-ray values. The boundary is defined by a marked change from high to lower gamma-ray values and very low to higher sonic values.

Distribution and thickness. The formation has only been found in wells in the southern part of the Danish Central Graben, where it forms an erosional remnant due to extensive mid-Jurassic erosion. The thickness of the formation is thus very variable; the maximum measured thickness of $257 \mathrm{~m}$ occurs in the Edna-1 well.

Age. In the M-8, O-1 and U-1 wells, the formation is dated to the Hettangian-Sinemurian (Michelsen 1978a); in the Edna-1 and Deep Gorm-1 wells, the upper part of the formation may extend up into the Lower Pliensbachian (Andsbjerg \& Dybkjær 2003, this volume).

\section{Bryne Formation}

revised formation

History. The Bryne Formation was defined in the Norwegian Central Graben (Vollset \& Doré 1984) and was described from the Danish Central Graben by Jensen et al. (1986). The deposits in the southern Danish Central Graben referred to the Lower Graben Sand Formation by Jensen et al. (1986) are here included in the Bryne Formation. The upper part of the Bryne Formation as adopted by Jensen et al. (1986) is here included in the new Lulu Formation. With this revision, usage of the Bryne Formation is in accordance with the original definition of the Bryne Formation by Vollset \& Doré (1984).

Type section. The Norwegian 9/4-3 well, 2613-2507.5 m b. KB (Vollset \& Doré 1984, fig. 29).

Reference section. The Danish Lulu-1 well, 12134-11712 $\mathrm{ft}$ b. KB, 3669-3540 m b. MSL, was selected as the Danish reference section by Jensen et al. (1986). However, new correlations show that much of the lower part of the formation is missing in Lulu-1, probably due to the location of the well on a salt structure that was active in Jurassic times. The more complete succession in the Danish West Lulu-1 well, 12602-11795 ft b. KB, 3801$3555 \mathrm{~m} \mathrm{~b}$. MSL, is selected as the new reference section (Fig. 16).

Lithology and environment. The Bryne Formation is characterised by laterally extensive sandstone units sep- arated by thick successions of interbedded sandstones and mudstones (Andsbjerg 1997). The laterally extensive sandstone bodies vary from fining-upwards or blocky units, $2-10 \mathrm{~m}$ thick, to more than $20 \mathrm{~m}$ thick amalgamated units (e.g. uppermost $20 \mathrm{~m}$ of Bryne Formation, Fig. 16B). The sandstones are light to medium grey and yellowish brown, very fine- to medium-grained. They are characterised by trough and planar cross-bedding, and ripple cross-lamination. Contorted bedding and other soft sediment deformation structures are also common. Associations of sedimentary structures that may indicate tidal influence occur in the uppermost laterally extensive sandstones, suggesting an origin as estuarine channel sands. Sandstones in the lower and middle parts of the formation were deposited in fluvial channels (Andsbjerg 2003, this volume). The successions that separate major sandstone units are fining-upwards or fining- to coarsening-upwards and commonly 20-60 $\mathrm{m}$ thick. They consist of grey to brown very fine- to medium-grained sandstones interbedded with siltstones, claystones and occasional thin coals. The sandstone beds are generally less than $2 \mathrm{~m}$ thick and show crossbedding, current ripple cross-lamination, climbing ripple cross-lamination, parallel lamination and chaotic bedding. Dark to light grey mudstone and siltstone beds may be up to $5 \mathrm{~m}$ thick, and most commonly are structureless or show parallel lamination. The finegrained deposits represent a variety of overbank environments ranging from crevasse splays and crevasse channels through distal levee to ponds and lakes. Abundant root traces, thin coals and strongly mottled silt- and mudstones testify to vegetated substrates and soil development.

Log characteristics. Most of the lithologies are easily distinguished on gamma-ray logs. However, coals are best recognised on the sonic log as distinct low-velocity peaks while high-velocity peaks reflect carbonate-cemented

\section{Following two pages:}

Fig. 16. A: West Lulu-1 well, located in the Søgne Basin, Danish Central Graben; new reference section for the Bryne Formation, 3801-3555 m b. MSL. Cored section indicated by solid bar and illustrated in $\mathbf{B}$. Note that the boundary between the Lulu and Lola Formations in this well is marked by the change from a coal bed to marine mudstones and is thought to be a faulted contact (Fig. 16B; Andsbjerg 2003, this volume). For legend, see Fig. 5. 
A

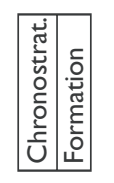

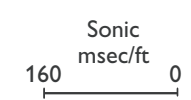

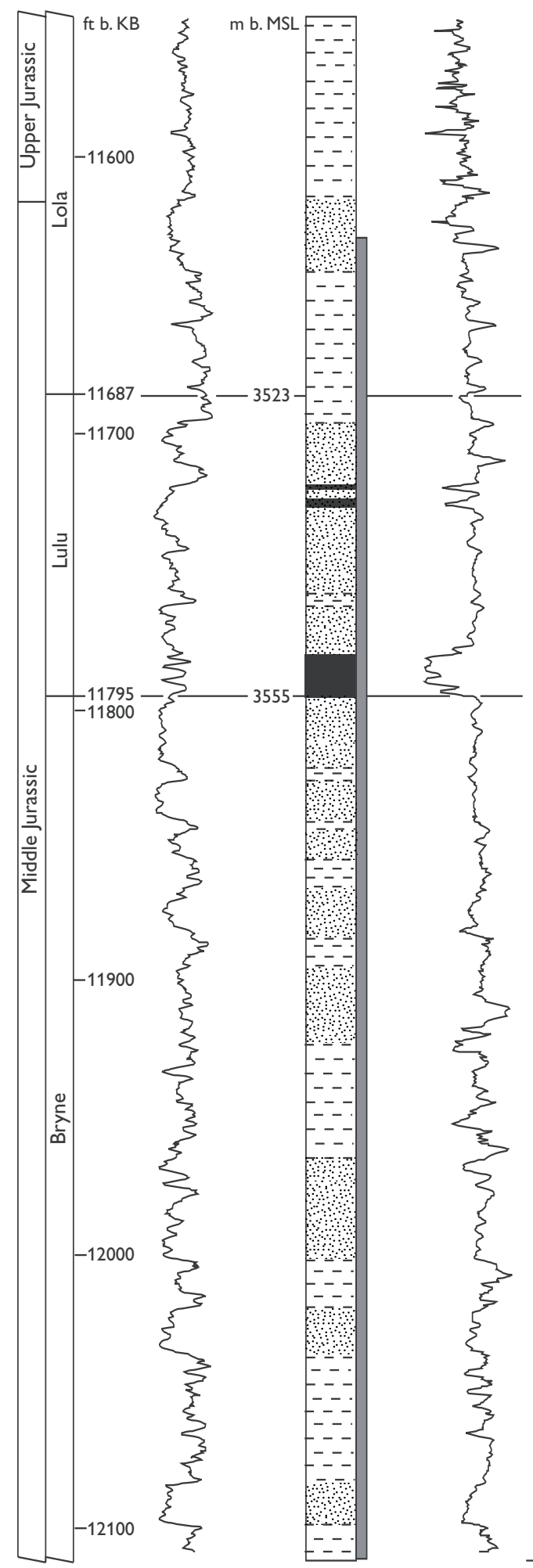

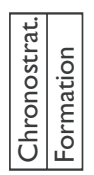
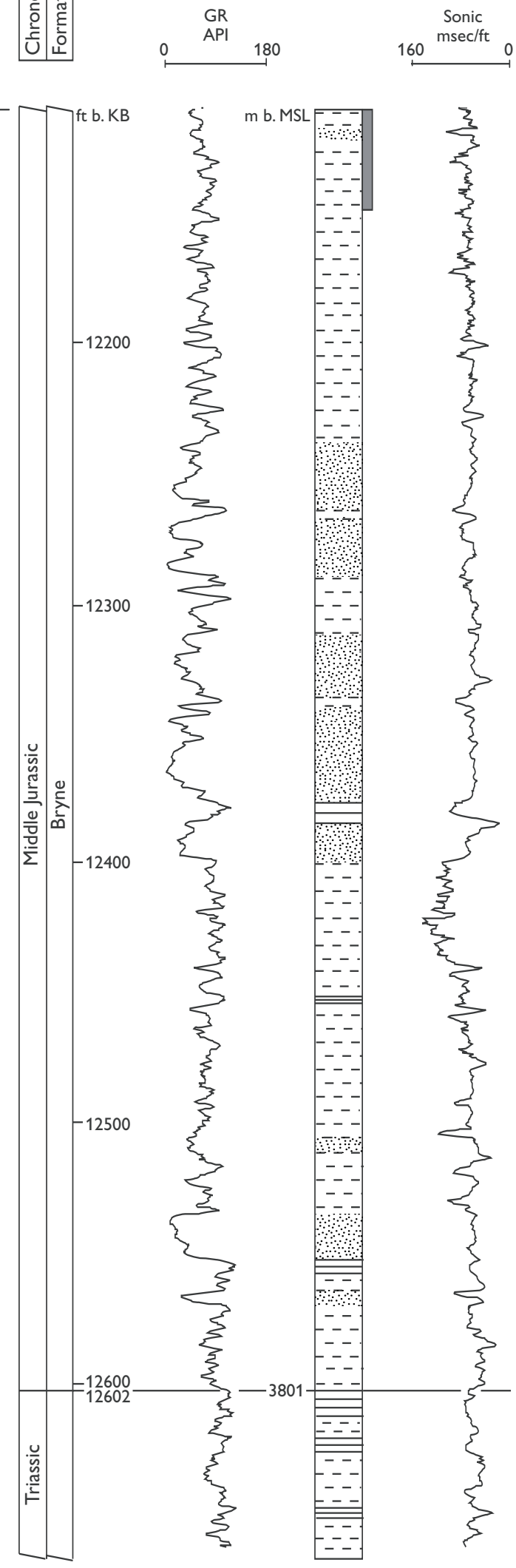
B
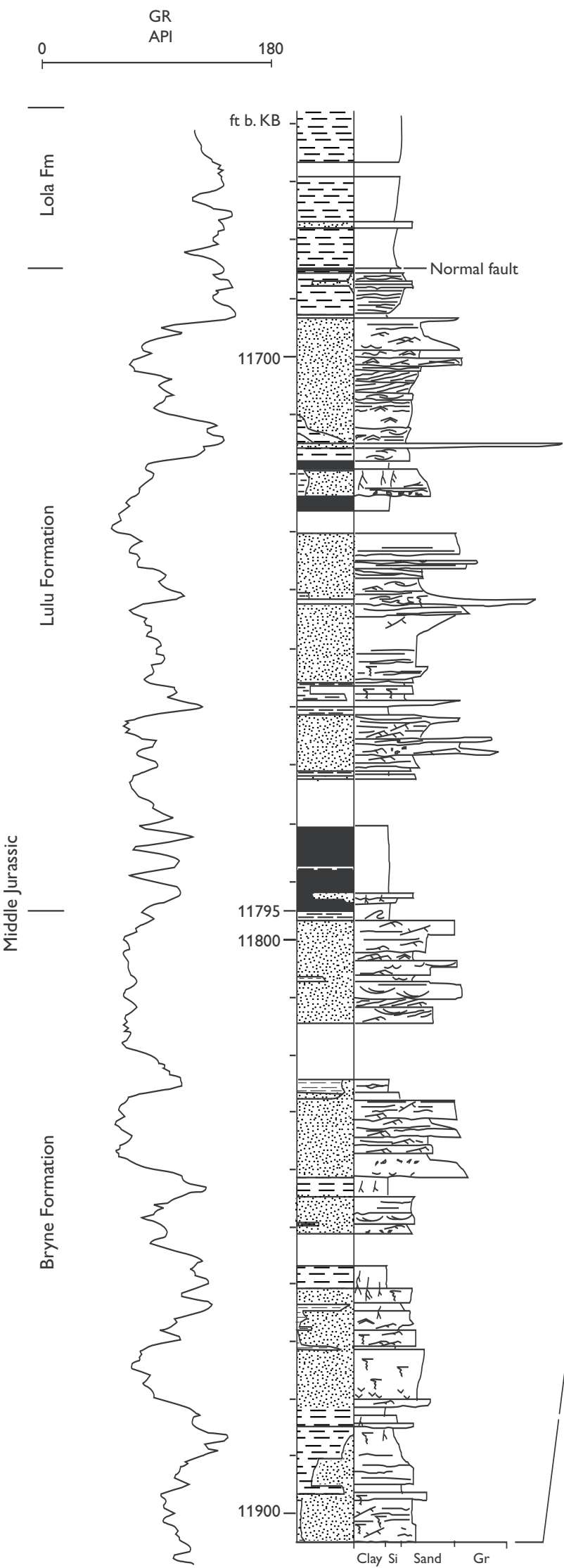

West Lulu-1
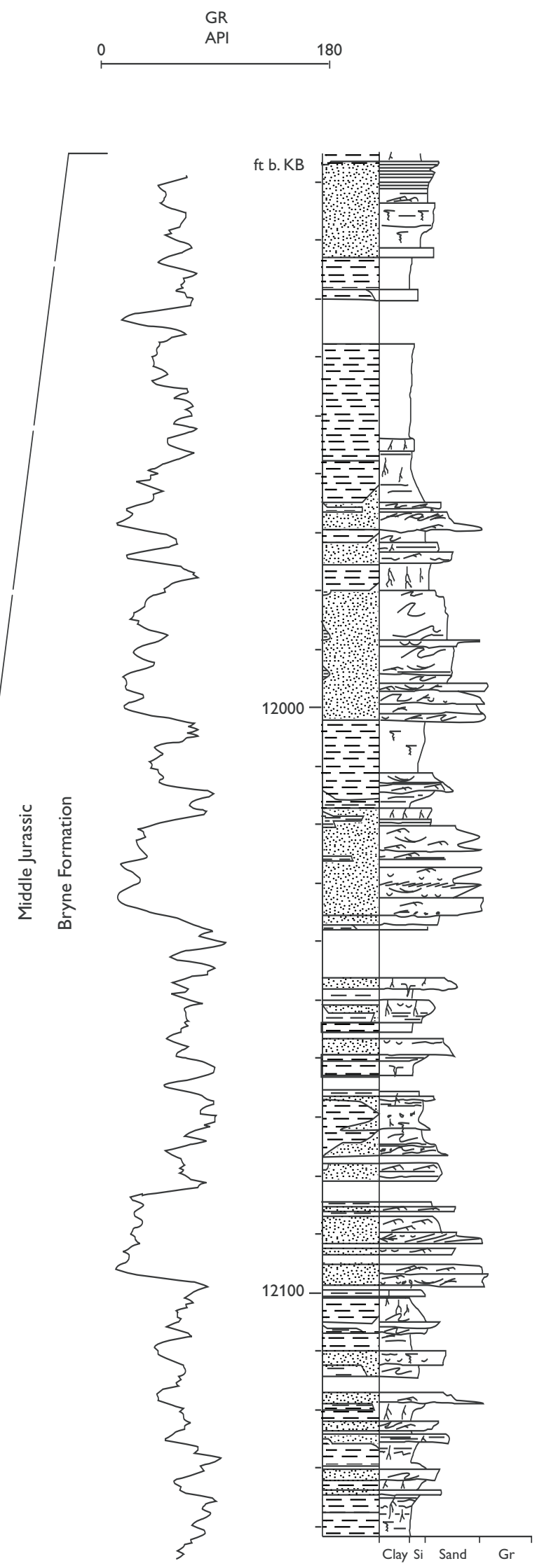
deposits. The gamma-ray logs typically show low values for the sandstones. Channel sandstones may show gamma-ray values that increase upwards, indicative of fining-upwards units (e.g. Fig. 16B, 12035-12016 ft b. $\mathrm{KB}$ ), or box-like, uniformly low values (e.g. Fig. 16B, $11840-11797 \mathrm{ft}$ b. KB). The intermediate to high gammaray values of floodplain deposits commonly show increasing-upwards (e.g. Fig. 16A, 12512-12437 ft b. $\mathrm{KB}$ ) or increasing-upwards to decreasing-upwards (e.g. Fig. 16A, 12200-12165 ft b. KB) gamma-ray patterns.

Lower boundary. The Bryne Formation unconformably overlies claystones of the Lower Jurassic Fjerritslev Formation in the southern part and Triassic and Permian rocks in the northern part of the Danish Central Graben. The boundary is marked by a distinct increase in gammaray values where the Bryne Formation overlies Permian salt, whereas the boundary elsewhere may vary from highly distinct to indistinct depending upon the underlying lithology.

Distribution and thickness. The formation is found in the Søgne Basin, in the Tail End Graben, in the Salt Dome Province and along the south-eastern fringe of the Heno Plateau. The thickness of the Bryne Formation is very variable, varying from a few tens of metres in marginal parts of the basin to commonly more than $200 \mathrm{~m}$. The thickest section, $289 \mathrm{~m}$, was recorded in the Amalie-1 well in the southernmost Søgne Basin (base not penetrated).

Age. The relatively sparse palynological data suggest that the lower part of the Bryne Formation is Aalenian or earliest Bajocian in age. Based on the occurrence of the dinoflagellate cyst Impletosphaeridium varispinosum in the uppermost estuarine sandstones of the Bryne Formation in the West Lulu-1 and West Lulu-3 wells, the top of the Bryne Formation is dated to the latest Bathonian - earliest Callovian (Andsbjerg \& Dybkjær 2003, this volume).

Remarks. The Middle Jurassic deposits of the Søgne Basin in the northern part of the Danish Central Graben were previously referred to the Bryne Formation (Jensen et al. 1986). The uppermost part of the succession consists of interfingering shallow marine and paralic sandstones and mudstones; this uppermost unit differs from the remainder of the Middle Jurassic succession both in terms of lithology and depositional environment. In accordance with the original definition of the Bryne Formation (Vollset \& Doré 1984), these deposits are no longer assigned to the Bryne Formation but are referred to the new Lulu Formation (defined below), equivalent to the Sandnes Formation in the Norwegian sector.

The Middle Jurassic succession in the southern part of the Danish Central Graben was referred to the Central Graben Group (the Central Graben Subgroup of van Adrichem Boogaert \& Kouwe 1994) by Jensen et al. (1986) as well control was missing in the central part of the graben. However, with more well data available it has become clear that the lower part of the Middle Jurassic succession in the southern Danish Central Graben shows greater affinity to the Bryne Formation than to the Lower Graben Formation as originally defined by NAM \& RGD (1980) and modified by van Adrichem Boogaert \& Kouwe (1994). In core sections, it is evident that with respect to both lithology and depositional environment this part of the succession cannot be distinguished from that of the Bryne Formation of the northern Danish Central Graben. It is thus proposed to include the Middle Jurassic deposits from the southern Central Graben in the Bryne Formation.

\section{Lulu Formation}

new formation

History. The succession that makes up the new Lulu Formation was included in the upper part of the Bryne Formation by Jensen et al. (1986). Vollset \& Doré (1984) defined the equivalent succession in the Norwegian sector, penetrated in the Fiskebank Basin and the Egersund Subbasin, as a separate formation, the Sandnes Formation. This unit is missing from most of the more than $100 \mathrm{~km}$ wide area that separates the southern part of the Søgne Basin from the central Fiskebank Basin. It is thus preferred not to adopt the term Sandnes Formation for the unit in the southern Søgne Basin and northern Tail End Graben.

Name. From the Lulu structure in the Søgne Basin which was the target for the Lulu-1 well (Fig. 1C).

Type section. The Danish Lulu-1 well, 11813-11715 ft b. KB, 3571-3541 m b. MSL (Fig. 17).

Reference section. The Danish West Lulu-3 well, 12035$11865 \mathrm{ft}$ b. KB, 3633-3581 m b. MSL (Fig. 18).

Lithology and environment. The Lulu Formation is characterised by coarsening-upwards wedges of shallow 
Lulu-1

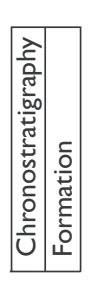

Type section: Lulu Formation

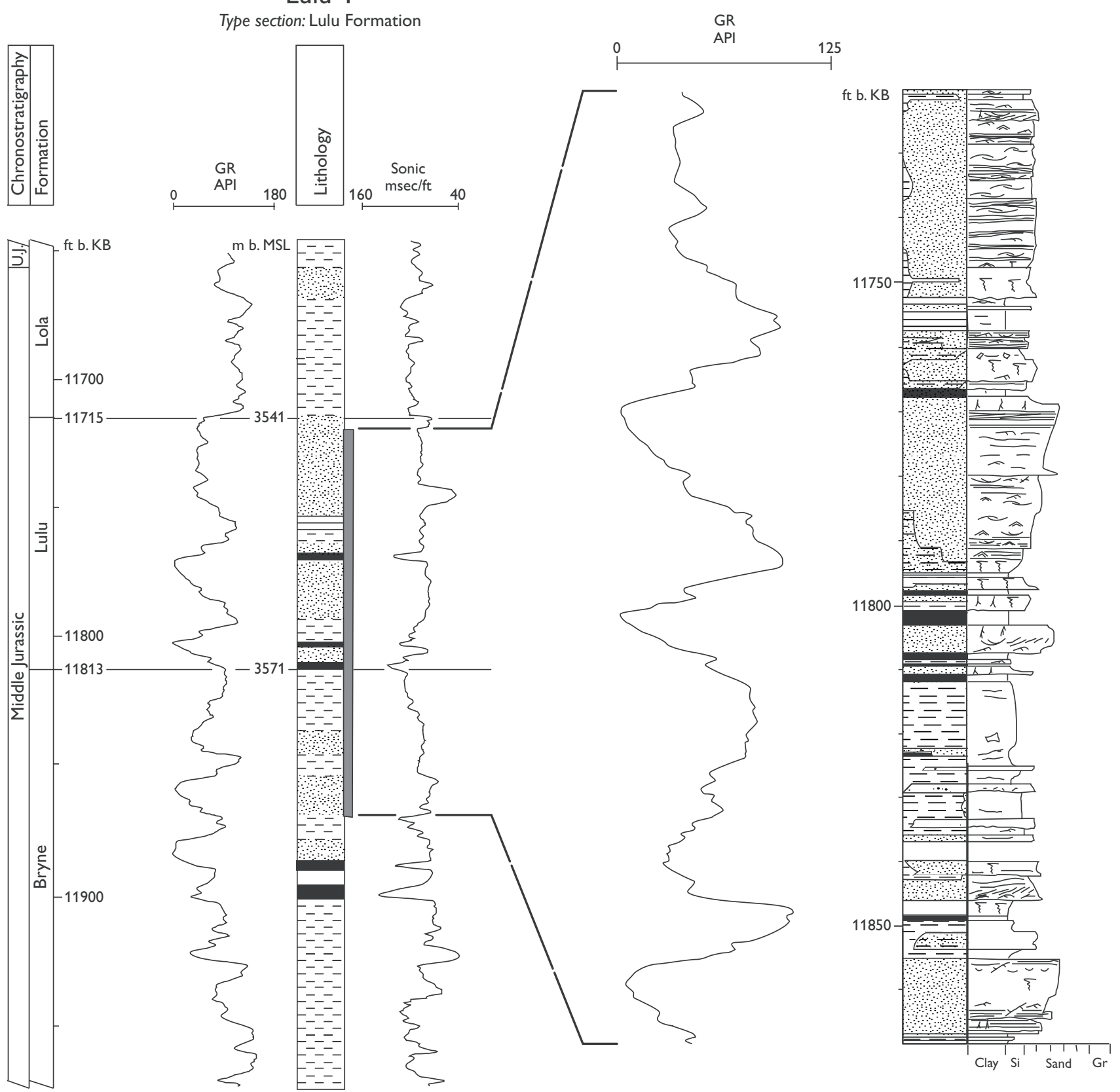

Fig. 17. Lulu-1 well, located in the Søgne Basin, Danish Central Graben; type section for the new Lulu Formation, 3571-3541 m b. MSL. Cored section indicated by solid bar and illustrated in the core log. U.J., Upper Jurassic. For legend, see Fig. 5.

marine sandstones, which interfinger with paralic sandstone successions towards the western basin margin. Laterally extensive coaly claystones with coal seams, up to $5 \mathrm{~m}$ thick, are characteristic of the formation, in particular the lower part (e.g. Fig. 18, West Lulu-3, 12035-12009 ft b. KB). The shallow marine wedges in the deeper parts of the Søgne Basin and northern Tail End Graben each show an 8-12 $\mathrm{m}$ thick coarsening- upwards succession (Fig. 17, Lulu-1, 11794-11773 and 11757-11729 ft b. KB). These successions are dominated by hummocky cross-stratified sandstones with interbeds of mudstone and siltstone, overlain by gradually thicker and more coarse-grained sandstone beds showing swaley cross-stratification and planar crossbedding. The sandstones are light grey to greyish brown and most commonly well-sorted, very fine- to 
West Lulu-3

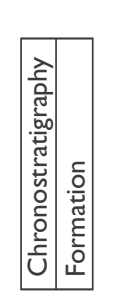

Reference section: Lulu Formation
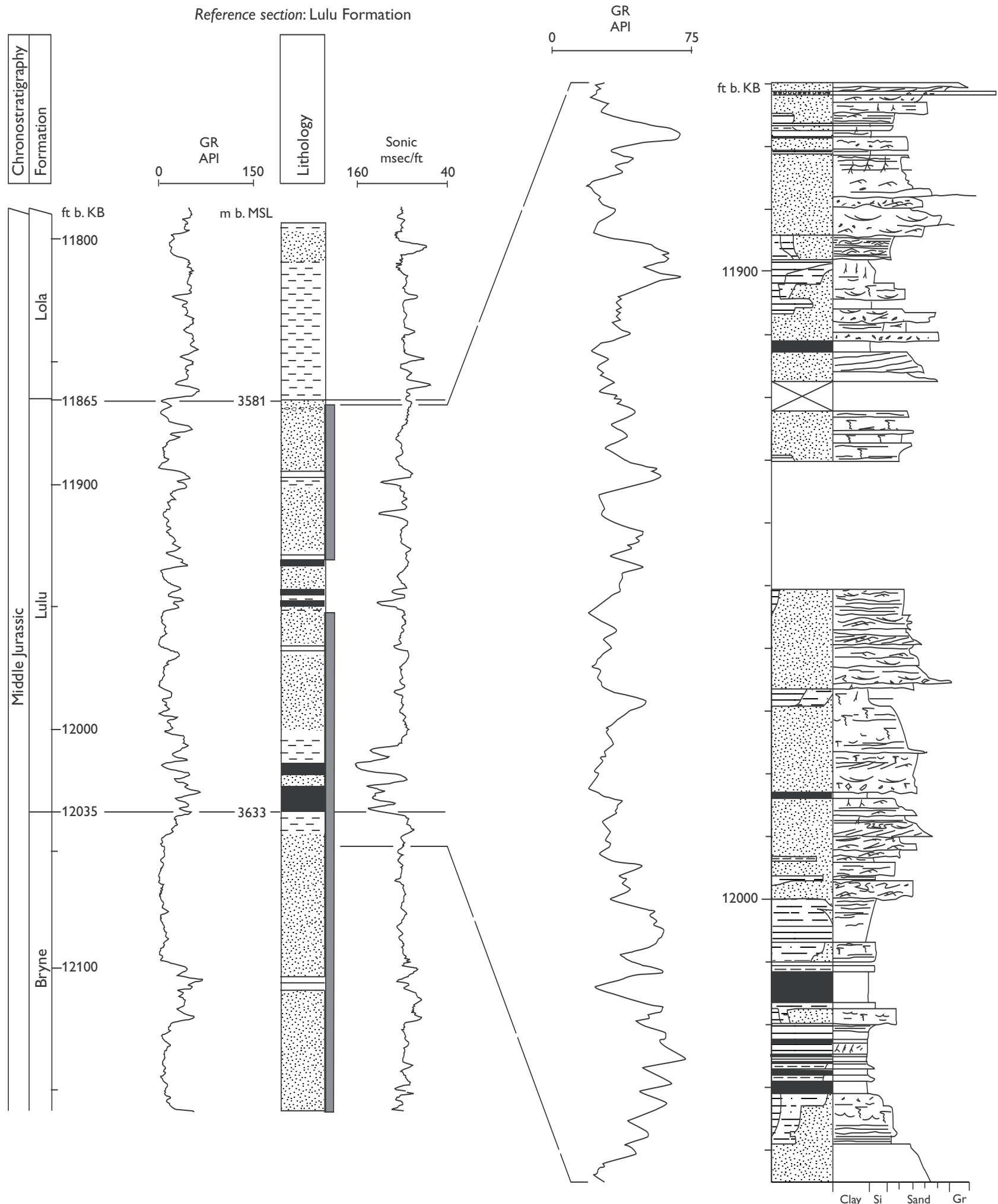

Fig. 18. West Lulu-3, located in the Søgne Basin, Danish Central Graben; reference section for the new Lulu Formation, 3633-3581 $\mathrm{m}$ b. MSL. Cored section indicated by solid bar and illustrated in the core log. For legend, see Fig. 5 . 
fine-grained. The coarsening-upwards successions are interpreted as prograding shoreface deposits.

Along the western margin of the Søgne Basin and Tail End Graben, the succession is dominated by backbarrier deposits, consisting mainly of sandstones with evidence for strong tidal influence. The sandstones are commonly moderately to well-sorted, dark and brownish grey to light brown, and show cross-bedding, current and climbing ripple-lamination and abundant double mud-drapes and bundled foresets. Bioturbated intervals occur commonly (Fig. 18, $11980 \mathrm{ft}$ b. KB in West Lulu-3). Only thin units of shallow marine sandstone and mudstone are present in the paralic wedges (Fig. 18, $11904 \mathrm{ft} \mathrm{b.} \mathrm{KB.} \mathrm{in} \mathrm{West} \mathrm{Lulu-3;} \mathrm{Andsbjerg}$ 2003, this volume). The coal seams, $0.1->1 \mathrm{~m}$ thick with a cumulative thickness of up to $5 \mathrm{~m}$, were deposited on a coastal plain during relative sea-level rise (Petersen \& Andsbjerg 1996).

Log characteristics. The heterogeneous lithologies are reflected by variable log patterns. Two 8-12 m thick units showing gamma-ray values that decrease upwards in the deeper parts of the Søgne Basin and Tail End Graben represent coarsening-upwards successions of shoreface and beach sandstones. In the western parts of the Søgne Basin and Tail End Graben, 0.5-5 m thick units show gamma-ray values that are consistently low or increase slightly upwards; these units represent channel fills. Units with high or decreasing-upwards gamma-ray values between the channel-fills represent lagoonal, tidal flat and bay-head delta environments (Andsbjerg 2003, this volume). Sonic log intervals $0.5-5 \mathrm{~m}$ thick that show very low sonic velocities (usually corresponding to low gamma-ray readings) represent coal deposits.

Lower boundary. The formation conformably overlies the Bryne Formation over most of the Danish Central Graben. The lower boundary is placed at the base of the lowermost laterally persistent major coal bed, or at the base of a correlative unit of interbedded sandstones and organic-rich mudstones with thin coals, as seen in Amalie-1 and Lulu-1.

Distribution and thickness. The Lulu Formation is widely distributed in the Søgne Basin and the northern Tail End Graben. In the southern part of the Tail End Graben and in the northern part of the Salt Dome Province, the Lulu Formation is replaced by the partly time-equivalent, mudstone-dominated Middle Graben Formation (NAM \& RGD 1980; Jensen et al. 1986; van Adrichem

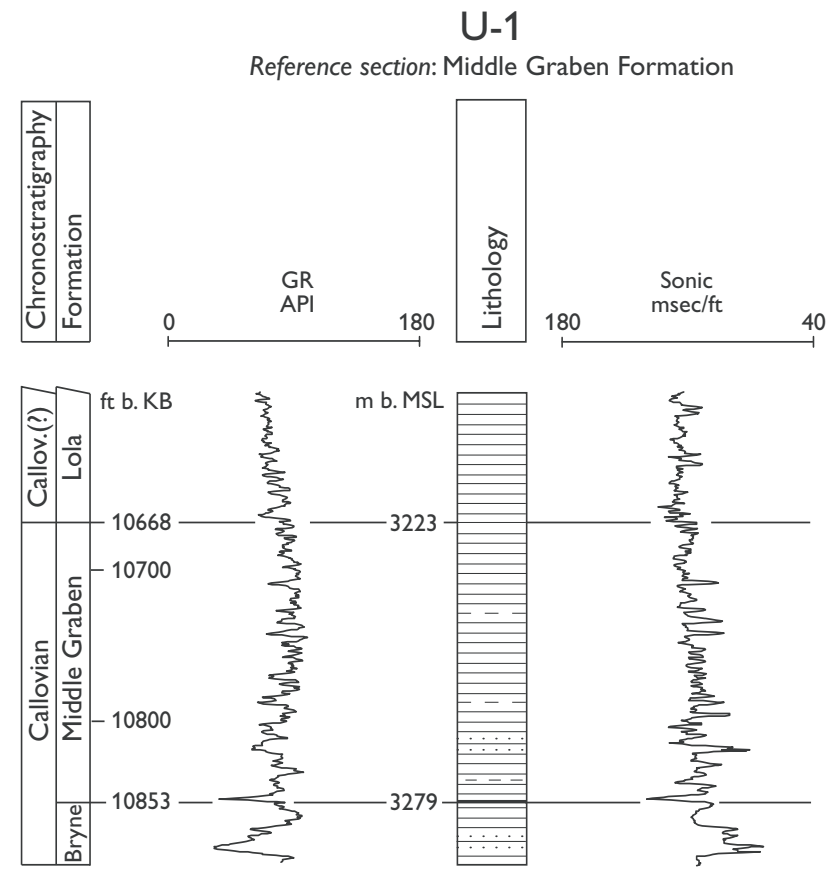

Fig. 19. U-1 well, located in the southern part of the Danish Central Graben; reference section for the Middle Graben Formation, 3279-3223 m b. MSL. Callov., Callovian. Modified from Jensen et al. (1986); for legend, see Fig. 5.

Boogaert \& Kouwe 1994). The thickness of the Lulu Formation varies from $30-60 \mathrm{~m}$.

Age. The formation is of Early-Late Callovian age. This is indicated by the occurrence of the latest Bathonian - earliest Callovian dinoflagellate cyst Impletosphaeridium varispinosum in the uppermost estuarine sandstones of the Bryne Formation in the West Lulu-3 well and the appearance of the Late Callovian - Middle Oxfordian dinoflagellate cyst Liesbergia scarburghensis in the basal part of the Lola Formation in several wells (Andsbjerg \& Dybkjær 2003, this volume).

\section{Middle Graben Formation}

History. The Middle Graben Shale Formation was defined in the Dutch North Sea sector by NAM \& RGD (1980), and extended to the Danish Central Graben by Jensen et al. (1986). The name was modified to the Middle Graben Formation by van Adrichem Boogaert \& Kouwe (1994). 


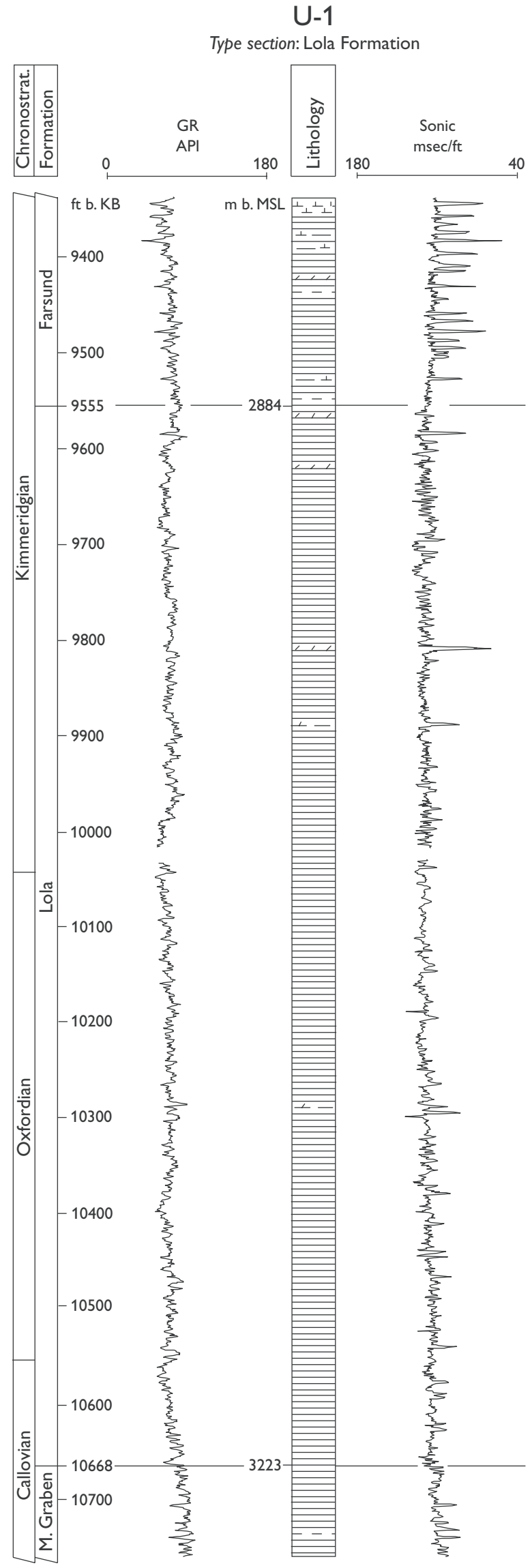

Type section. The Dutch F03-03 well, 3090-2670 m b. KB (NAM \& RGD 1980).

Reference section. The U-1 well, 10853-10668 ft b. KB, $3279-3223 \mathrm{~m} \mathrm{~b}$. MSL, is used as a reference section in the Danish sector (Fig. 19; Jensen et al. 1986).

Lithology and environment. The formation consists of dark brownish grey claystones interbedded with siltstones and rare sandstone beds. Coal beds, locally several metres thick, may occur in the lower part of the formation. Deposition took place in swampy environments, probably interdistributary bays or coastal lagoons.

Log characteristics. The gamma-ray log commonly shows a response slightly lower than the overlying Lola Formation but considerably higher than that of the underlying Bryne Formation. However, some coal beds may be characterised by a very low gamma-ray response and a low sonic velocity.

Lower boundary. The Middle Graben Formation in the Danish Central Graben overlies the Bryne Formation. The boundary is placed at the base of a prominent coal bed, usually the lowermost of a series of coal beds and commonly characterised by a low gamma-ray and a low sonic velocity log response.

Distribution and thickness. The formation extends from the southern North Sea into the Salt Dome Province of the Danish Central Graben. It is not recognised north of the Salt Dome Province, where the Bryne Formation is overlain by the Lulu Formation in the Danish sector. The thickness of the Middle Graben Formation ranges from $15-56 \mathrm{~m}$ in the Danish sector.

Age. Based on datings of the underlying deposits belonging to the Bryne Formation by Hoelstad (1986a), the formation is not older than Late Callovian. There is no good data to constrain the youngest age of the formation, although it probably ranges into the Early or Middle Oxfordian, based on the occurrence of the dinoflagellate cyst Liesbergia scarburghensis. The formation may be slightly diachronous, younging southwards to the

Fig. 20. U-1 well, located in the southern part of the Danish Central Graben; type section for the Lola Formation, 3223-2884 $\mathrm{m}$ b. MSL. M. Graben, Middle Graben. Modified from Jensen $e t$ al. (1986); for legend, see Fig. 5. 
Dutch North Sea area, where it has an Early-Middle Oxfordian age.

\section{Lola Formation}

History. The Lola Formation was defined by Jensen et al. (1986).

Type section. The U-1 well, 10668-9555 ft b. KB, 3223-2884 m b. MSL, in the Danish Central Graben (Fig. 20; Jensen et al. 1986).

Lithology and environment. The formation consists of dark olive-grey to grey claystones, with organic material, mainly of terrestrial origin. Deposition took place in a low energy, offshore open marine environment.

Log characteristics. The formation is characterised by fairly constant, high gamma-ray readings and relatively low sonic velocities. A few high velocity peaks corresponding to dolomite or limestone beds may occur (Fig. 20).

Lower boundary. The formation overlies the Lulu Formation in the northern part of the Danish Central Graben and the Middle Graben Formation in the southern part of the Danish Central Graben. On structurally high areas along the western margin of the Danish Central Graben and on local highs, the formation rests unconformably on Triassic or older strata. The lower boundary with the Lulu Formation is placed at an abrupt, fairly large increase in gamma-ray values and a minor decrease in sonic velocity (Figs 17, 18). The boundary with the Middle Graben Formation shows a sudden and fairly large drop in sonic velocity (Figs 19, 20).

Distribution and thickness. The formation is present in the eastern and southern parts of the Danish Central Graben. It thins west of the Tail End Graben and probably continues southwards and grades into the lower part of the Kimmeridge Clay Formation in the Dutch North Sea area (Michelsen \& Wong 1991). Maximum thicknesses of $c .1000 \mathrm{~m}$ occur in the Tail End Graben.

Age. Late Callovian/Early Oxfordian - Late Kimmeridgian. The base of the formation is considered diachronous, younging southwards. The uppermost part is not younger than Early Kimmeridgian in the Elly-2 well in the Tail End Graben (Andsbjerg \& Dybkjær 2003, this volume).

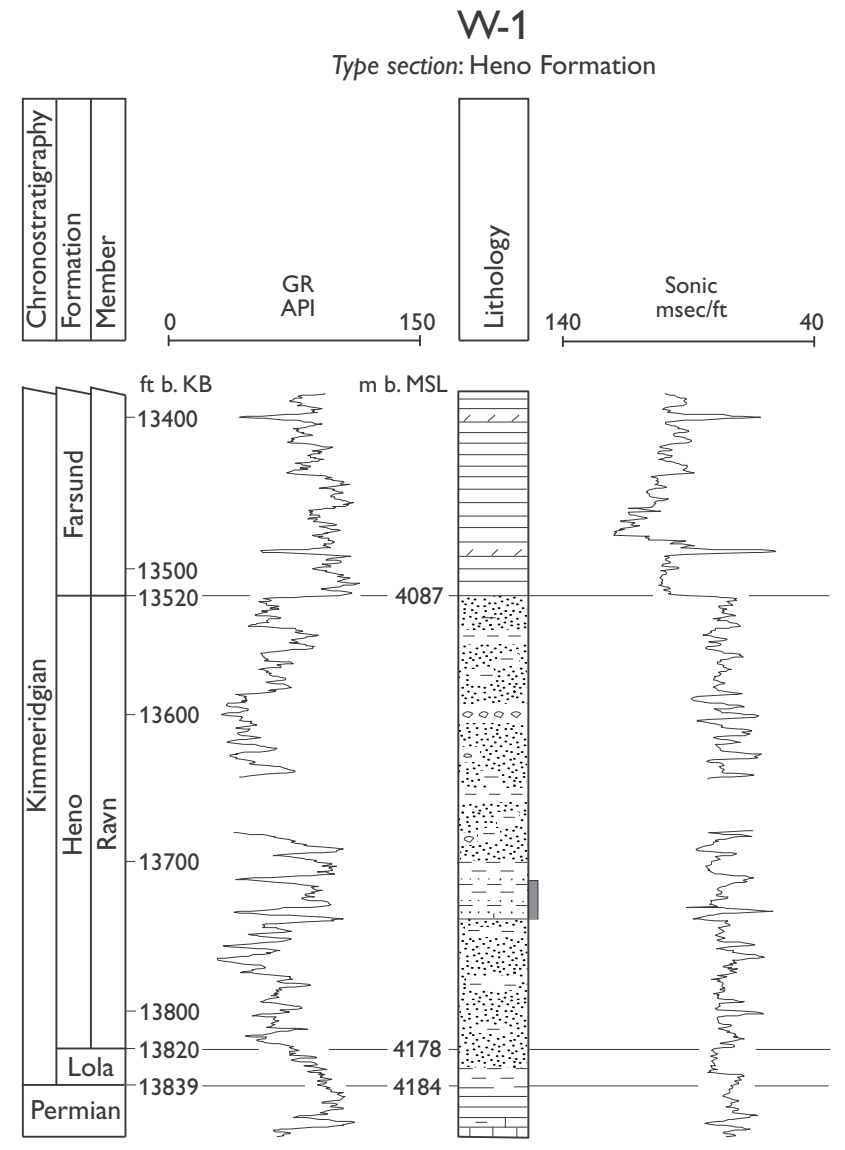

Fig. 21. W-1 well, located on the Heno Plateau, Danish Central Graben; type section for the Heno Formation, 4178-4087 m b. MSL. Modified from Jensen et al. (1986); for legend, see Fig. 5.

\section{Heno Formation}

revised formation

History. The Heno Formation was defined by Jensen et al. (1986) to include Upper Jurassic shallow marine sandstones in the Danish Central Graben. Wells drilled in recent years have demonstrated that sandstones of the Heno Formation interfinger with claystones of the Lola Formation. In the southern part of the Feda Graben, two sandstone units are separated by claystones and south and east of the Feda Graben, on the Heno and Gertrud Plateaus, clayey sandstones separate two discrete sandstone units. The type section of the Heno Formation, as defined by Jensen et al. (1986), comprises only the upper sandstone unit (the new Ravn Member). The informal terms 'basal sandstone unit' and 'Heno Equivalent' have been used for the lower sandstone unit by Bergan et al. (1989), Michelsen \& Wong (1991), Nielsen \& Japsen (1991), Söderström et al. (1991), 
Gert-1

Reference section: Heno Formation

Type section: Gert Member
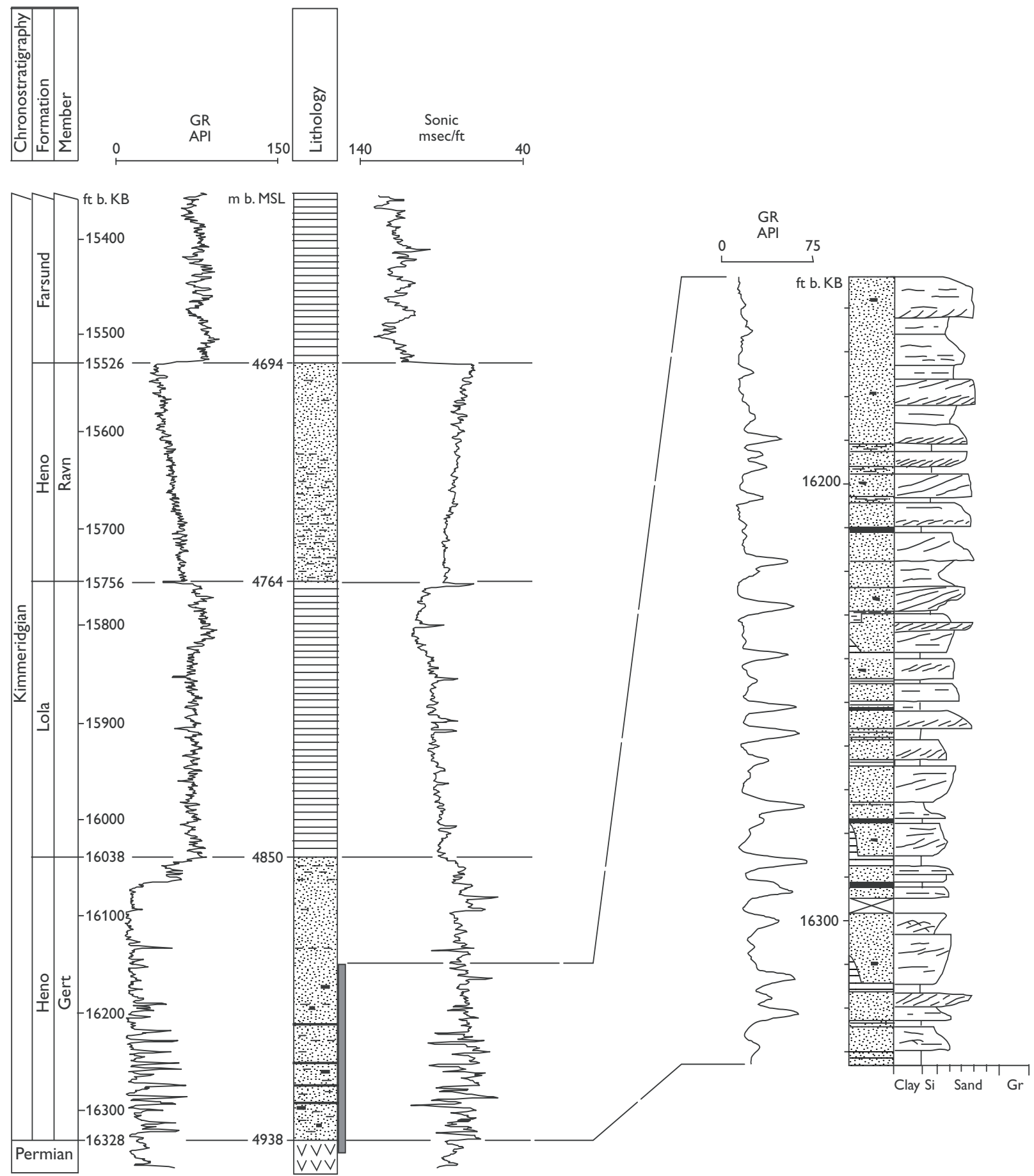

Fig. 22. Gert-1 well, located in the northern part of the Danish Central Graben; new reference section for the Heno Formation and type section for the new Gert Member (4938-4850 m b. MSL). Cored section indicated by solid bar and illustrated by core log. Note that this well also encountered the new Ravn Member (4764-4694 m b. MSL) separated from the Gert Member by $86 \mathrm{~m}$ of Lola Formation mudstones. For legend, see Fig. 5. 


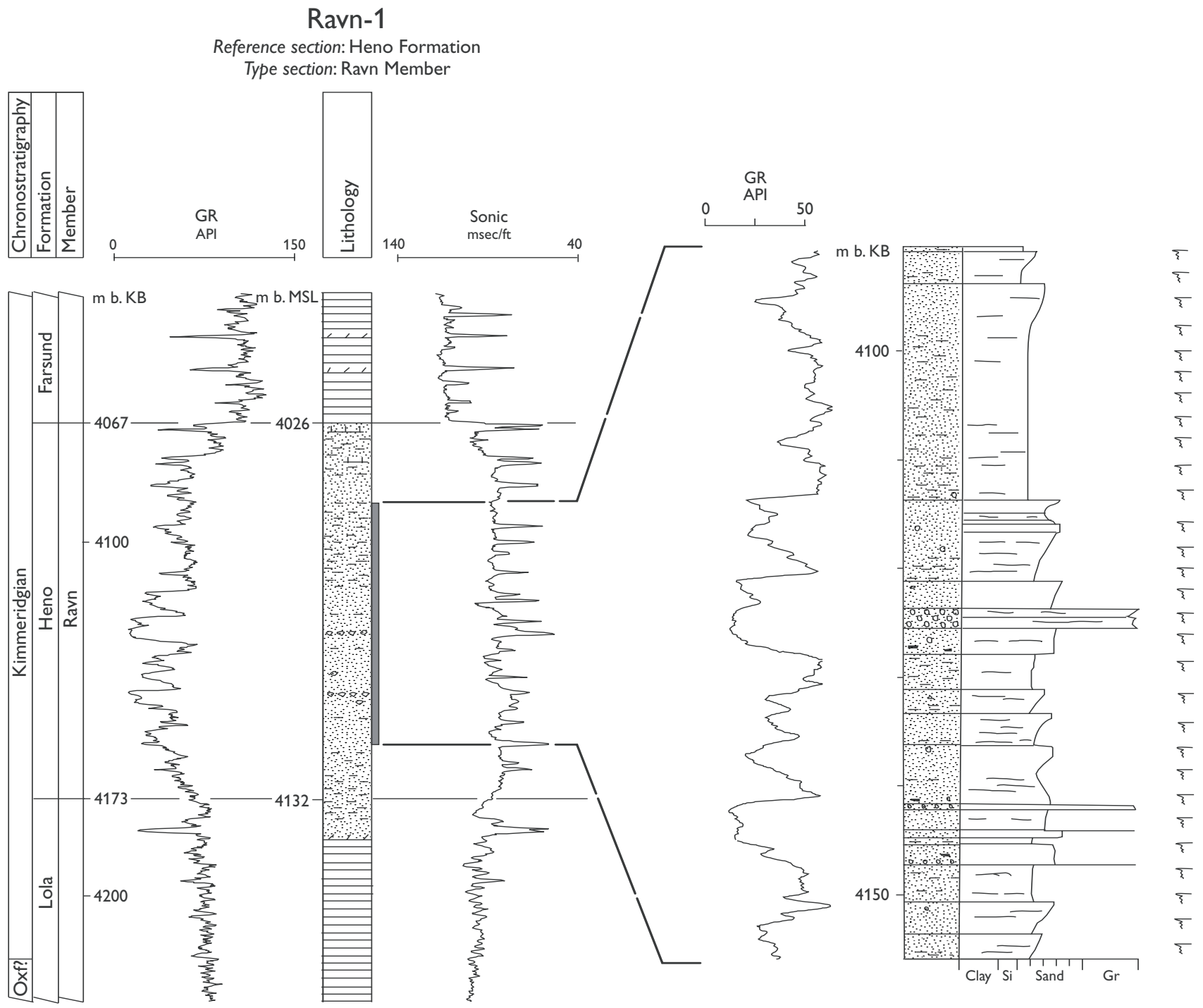

Fig. 23. Ravn-1 well, located on the Heno Plateau, Danish Central Graben; type section for the new Ravn Member (Heno Formation), 4132-4026 m b. MSL. Cored section indicated by solid bar and illustrated by core log. Oxf., Oxfordian. For legend, see Fig. 5.

Damtoft et al. (1992), Michelsen et al. (1992), Johannessen \& Andsbjerg (1993) and Johannessen et al. (1996). The revised Heno Formation, as proposed here, includes both sandstone units that are given the rank of members, the Gert and Ravn Members.

Type section. The W-1 well, 13820-13520 ft b. KB, 4178-4087 m b. MSL, in the Central Graben, Heno Plateau, was selected as type section by Jensen et al. (1986; Fig. 21).

Reference section. The Gert-1 well in the easternmost part of the Feda Graben bordering the Gertrud Plateau, and the Ravn-1 well on the Heno Plateau are here selected as reference sections for the Heno Formation
(Figs 22, 23). In the Gert-1 well, the lower sandstones, $16328-16038 \mathrm{ft}$ b. KB, 4938-4850 m b. MSL, are referred to the Gert Member and the upper sandstones, 15756-15526 ft b. KB, 4764-4694 m b. MSL, are referred to the Ravn Member. Claystones of the Lola Formation lie between the two members. In the Ravn-1 well, the sandstone interval $4173-4067 \mathrm{~m} \mathrm{~b}$. KB, $4132-4026 \mathrm{~m}$ b. MSL, is referred to the Ravn Member.

Lithology and environment. The formation consists of predominantly grey to white very fine- to fine-grained sandstones and minor siltstones interbedded with claystones and coal beds. Conglomerate beds, $0.08-2 \mathrm{~m}$ thick, are present on plateau areas. The Gert Member was deposited in a back-barrier and marine shoreface environment while 
Jeppe-1

Reference section: Gert Member
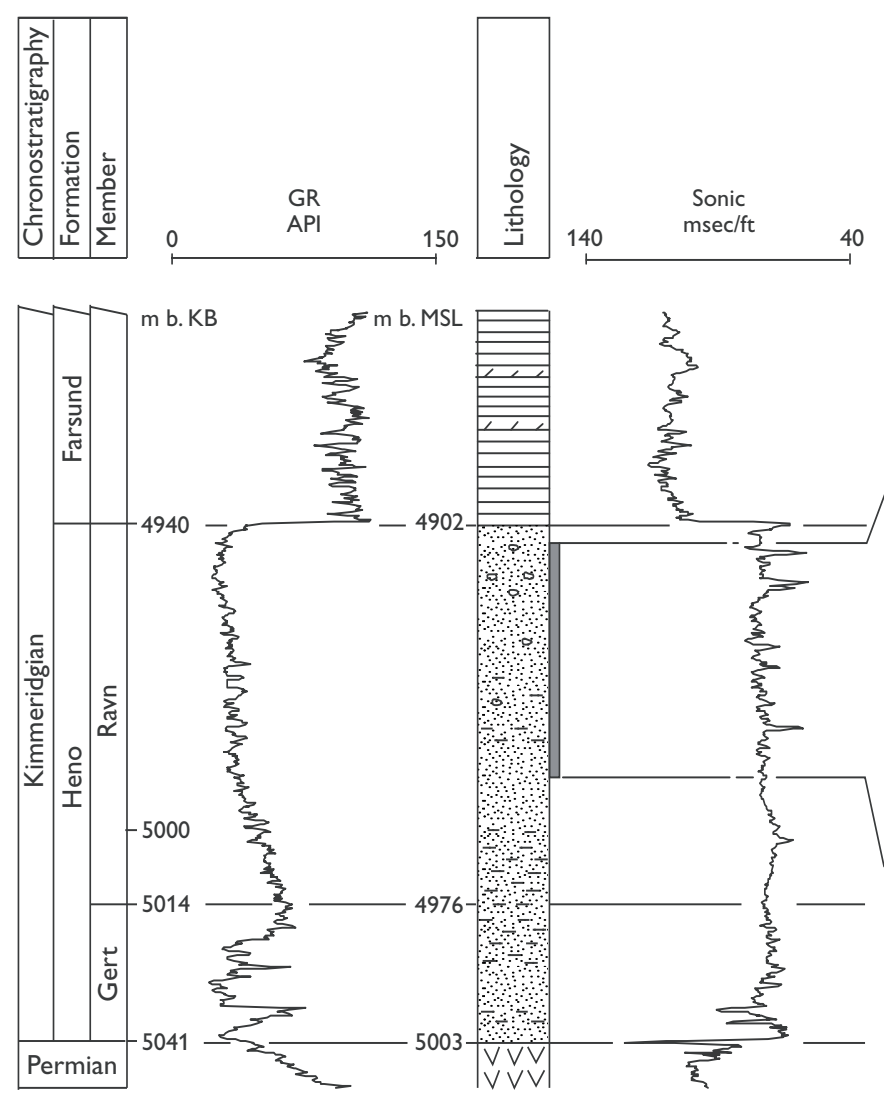

Fig. 24. Jeppe-1 well, located in the northern part of the Danish Central Graben; reference section for the new Gert Member (Heno Formation), 5003-4976 m b. MSL. For legend, see Fig. 5.

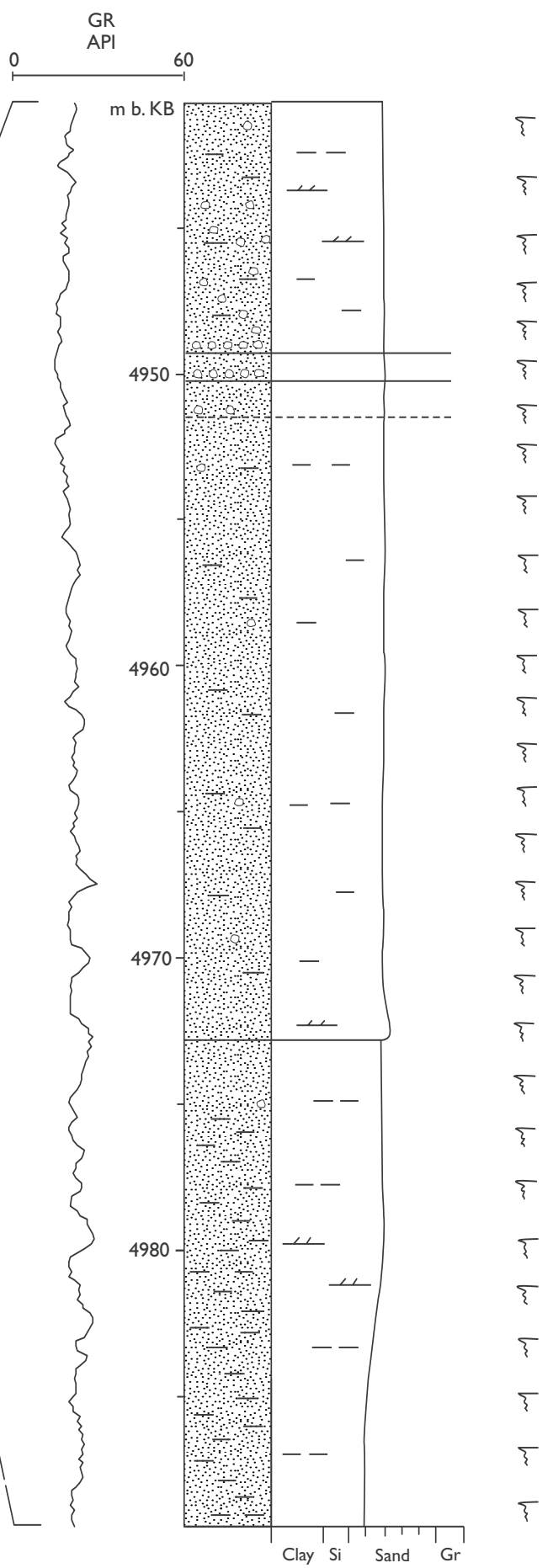

Lower boundary. In the type section, the formation rests on Upper Oxfordian - Lower Kimmeridgian claystones of the Lola Formation (Andsbjerg \& Dybkjær 2003, this volume). In the Gert-1 well, the base of the formation is defined by the base of the lowermost sandstones and claystones of the Gert Member unconformably overlying Lower Permian volcanic rocks. 
Distribution and thickness. The formation is present in the Feda Graben and on the Gertrud and Heno Plateaus in the northern part of the Danish Central Graben. The maximum thickness of the formation on the Heno Plateau is 106 m in the Ravn-1 well. In the Feda Graben, the total thickness of the Heno Formation is $158 \mathrm{~m}$ in the Gert-1 well (Gert Member 88 m, and Ravn Member $70 \mathrm{~m}$ ), where the formation interfingers with $86 \mathrm{~m}$ of claystones of the Lola Formation.

Age. The formation was assigned a Middle-Late Oxfordian to Kimmeridgian age (Jensen et al. 1986), but new biostratigraphic data indicate a latest Early - Late Kimmeridgian age (Andsbjerg \& Dybkjær 2003, this volume).

Subdivision. In the eastern part of the Feda Graben, the Gertrud Plateau and the western part of the Heno Plateau, the lower part of the formation is characterised by a serrated gamma-ray and sonic log pattern including very high gamma-ray peaks corresponding to very low sonic values, recording the presence of thin coal and clay beds within the sand-dominated section. This part of the formation is defined as the new Gert Member, described below. In the same area, the upper part of the formation is characterised by moderate to low gamma-ray and moderate to high sonic readings representing sandstone facies seen in the type section of the W-1 well. This part of the formation is defined as the new Ravn Member, described below. The type section of the Heno Formation in the W-1 well comprises only the Ravn Member (Fig. 21).

Remarks. Other shallow marine sandstones somewhat younger than the Heno Formation may be present in the western part of the Danish area (Damtoft et al. 1992). A sandy siltstone succession in the Kim-1 well at the eastern margin of the Grensen Nose Basin is thought to be a distal equivalent of the Early-Middle Volgian shallow marine 'Fife sandstones' in the UK sector (Mackertich 1996; Andsbjerg \& Dybkjær 2003, this volume). Similar sandstones are expected to be present in the intervening area of the $\AA$ ll and Grensen Nose Basins.

\section{Gert Member}

new member

Name. The Gert Member is named after the Gert Ridge situated at the eastern margin of the Feda Graben.
Type section. The Gert-1 well, 16328-16038 ft b. KB, $4938-4850 \mathrm{~m}$ b. MSL, is proposed as the type section (Fig. 22).

Reference section. The Jeppe-1 well, 5041-5014 m b. KB, $5003-4976 \mathrm{~m}$ b. MSL, on the Gertrud Plateau, is selected as the reference section (Fig. 24).

Lithology and environment. The member consists predominantly of grey to white very fine- to fine-grained sandstones and minor siltstones interbedded with claystones and coal beds (Fig. 22). The sediments were deposited in back-barrier and shoreface environments.

Log characteristics. The lower part of the member in the type section is characterised by serrated gamma-ray and sonic log motifs. Log readings from the upper part are more uniform and smooth. The very high gammaray values and very low sonic values in the serrated section represent thin claystone and coal beds interbedded with sandstones. The upper part with low gamma-ray and high sonic values consists of clean sandstones without coal and clay beds. The uppermost part of the member is characterised by a step-wise increase in gamma-ray values and decrease in sonic values, representing a fining-upwards succession from sandstones to the claystones of the overlying Lola Formation (Fig. 22).

Boundaries. In the type and reference sections, the member rests unconformably on Lower Permian volcanic rocks. In the Gert-1 well, the upper boundary is defined at the change to the clay-dominated Lola Formation marked by a significant log shift to higher gamma-ray values and lower sonic velocities. In the Jeppe-1 well reference section (Fig. 24) and the Gert-2 well, the Gert Member is directly overlain by the Ravn Member, as offshore claystones of the Lola Formation are absent. In these wells, the top of the Gert Member is defined at the highest gamma-ray and lowest sonic readings, defining the base of the coarsening-upwards Ravn Member.

Distribution and thickness. The member is present in the northern part of the Danish Central Graben with a maximum thickness of $88 \mathrm{~m}$ in the Gert-1 well at the eastern margin of the Feda Graben. On the adjacent Gertrud Plateau, the thickness of the member is reduced to $27 \mathrm{~m}$ in the Jeppe- 1 well and to $23 \mathrm{~m}$ in the Gert- 2 well.

Age. The member is of latest Early - Late Kimmeridgian age (Johannessen et al. 1996; Andsbjerg \& Dybkjær 2003 , this volume). 


\section{Gwen-2}

Reference section: Ravn Member

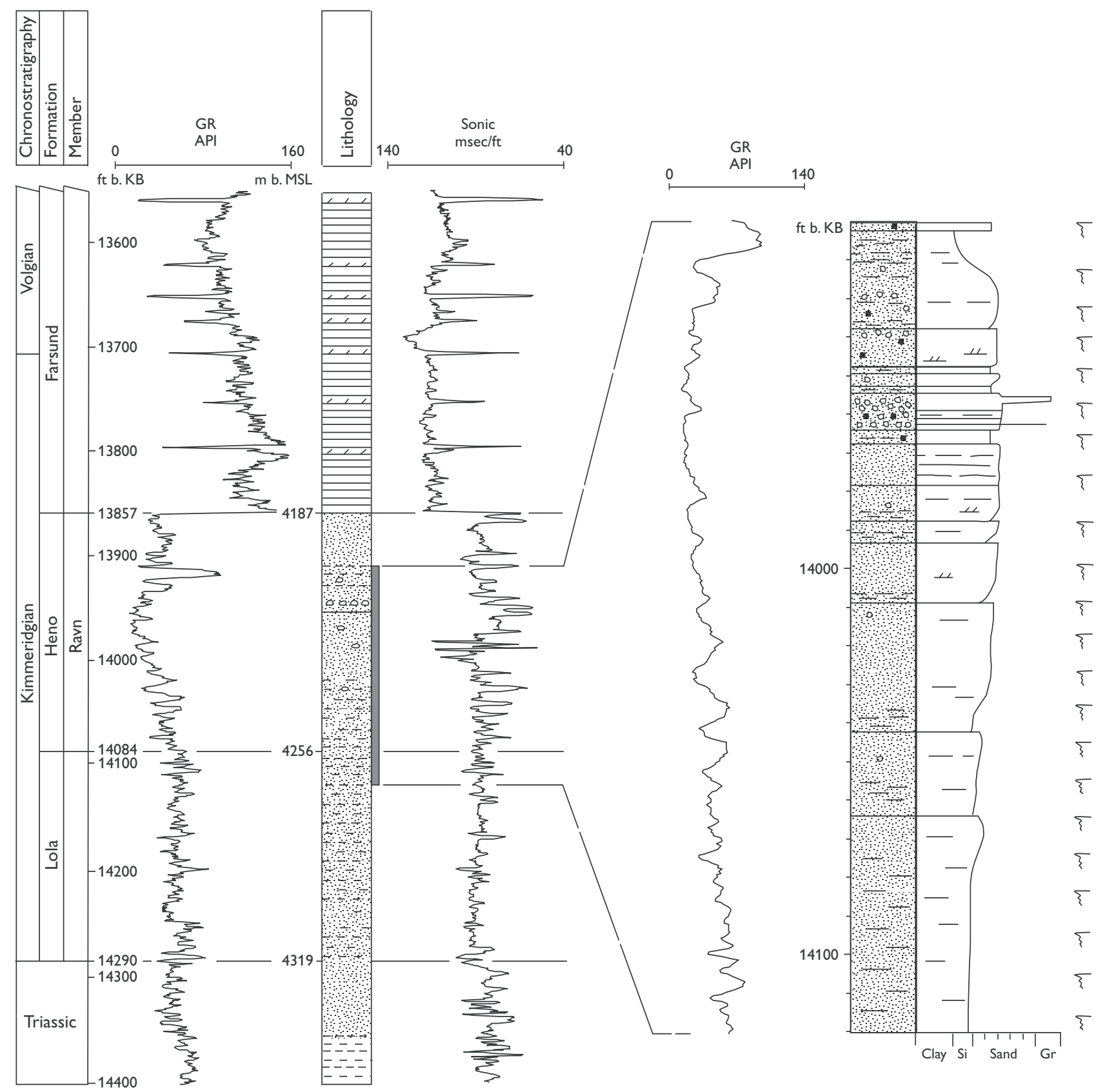

Fig. 25. Gwen-2 well, located on the Gertrud Plateau, Danish Central Graben; reference section for the new Ravn Member (Heno Formation), 4256-4187 m b. MSL. Modified from Jensen et al. (1986); for legend, see Fig. 5.

Ravn Member

new member

Name. The member is named after the Ravn-1 and Ravn-2 wells situated on the south-eastern part of the Heno Plateau (Fig. 1C).
Type section. The Ravn-1 well, 4173-4067 m b. KB, 4132$4026 \mathrm{~m}$ b. MSL, is selected as the type section (Fig. 23).

Reference section. The Gwen-2 well, 14084-13857 ft b. $\mathrm{KB}, 4256-4187 \mathrm{~m} \mathrm{~b}$. MSL, on the Gertrud Plateau, is selected as the reference section (Fig. 25). 
Lithology and environment. The Ravn Member consists predominantly of grey to white, very fine- to fine-grained sandstones, muddy sandstones and minor siltstones that are bioturbated to such a degree that almost no primary sedimentary structures are preserved (Fig. 23). Conglomerate beds, $0.08-2 \mathrm{~m}$ thick, locally associated with mediumgrained sandstones, are present on plateau areas. In the graben areas, the member is dominated by clayey, very fine-grained sandstones and siltstones. Calcareous beds and/or concretions occur. Deposition took place in a marine shoreface environment. The conglomerates represent river or beach deposits that were later winnowed during transgressive erosion (Johannessen et al. 1996; Johannessen 2003, this volume).

Log characteristics. In the Ravn-1 and Gwen-2 wells (Figs 23, 25), the lower and upper parts of the member include clayey sandstones characterised by relatively high gamma-ray and low sonic readings. The middle part of the member consists of sandstones and conglomerates characterised by low gamma-ray and high sonic readings. The overall pattern is thus characterised by decreasing-upwards gamma-ray values and increasing-upwards sonic values followed by increasing gamma-ray values and decreasing sonic values. In the Gert- 1 and Jeppe- 1 wells, the member does not include clayey sandstones in the upper part (Figs 22, 24). The gamma-ray and sonic logs are strongly serrated in the Ravn-1 well, less serrated in Gwen-2, and relatively smooth in Gert-1 and Jeppe-1 (Figs 22-25). This may be due to variation in the development of calcareous beds and/or concretions.

Lower boundary. The member overlies offshore claystones of the Lola Formation in the Ravn-1 well type section. The base of the member is defined by a shift to lower gamma-ray and higher sonic readings marking the base of an overall coarsening-upwards succession beginning with clayey sandstones (Figs 23, 25). In the Gwen-2 reference section and the Gert- 1 well, the member overlies sandy offshore claystones of the Lola Formation (Figs 22, 25), whereas in the Jeppe-1 well, the Ravn Member directly overlies the Gert Member (Fig. 24).

Distribution and thickness. The member is present in the Feda Graben and on the Gertrud and Heno Plateaus in the northern part of the Danish Central Graben. A maximum thickness of $106 \mathrm{~m}$ is found in the Ravn-1 well on the southern part of the Heno Plateau.
Age. The member is of Late Kimmeridgian age (Andsbjerg \& Dybkjær 2003, this volume).

\section{Farsund Formation}

History. The Farsund Formation was defined by Vollset \& Doré (1984) in the Norwegian North Sea area and extended to the Danish Central Graben by Jensen et al. (1986). New correlations have shown that Jensen et al. (1986) placed the lower boundary of the formation at a lower stratigraphic level than that defined by Vollset \& Doré (1984). In addition, Forsberg et al. (1993) pointed out a discrepancy between the base of the Farsund Formation as picked by Vollset \& Doré (1984) in their type well (2/7-3) and that picked in their reference well (2/8-3); neither of these picks correspond with that suggested by Jensen et al. (1986).

The practice of Jensen et al. (1986) is followed here as they defined the boundary at a distinct and easily recognisable log change that marks a significant change in depositional style, which is probably related to changes in subsidence patterns (Andsbjerg \& Dybkjær 2003, this volume). However, the upper part of the formation is missing from the U-1 well that was chosen as the Danish reference well for the Farsund Formation by Jensen et al. (1986). A new reference well, the G-1 well, is thus introduced here.

Type and reference sections. The Norwegian 2/7-3 well, 3626-3414 m b. KB, is the type section; the G-1 well in the Danish Central Graben, 12036-7863 ft b. KB, $3631-2359 \mathrm{~m}$ b. MSL, is designated as a reference section in the Danish sector (Fig. 26). A correlation line showing the stratigraphic relationship between the Norwegian reference well 2/8-3 and three Danish wells including the reference well G-1 and the old reference well $\mathrm{U}-1$ is depicted in Figure 27.

Lithology and environment. The Farsund Formation consists of medium to dark grey claystones; they are carbonaceous and variably calcareous, and are intercalated with numerous thin beds of brownish dolomite. The organic matter is mainly liptinitic, and deposition took place in a relatively deep marine environment. Thin units of turbidite sandstones occur locally in the deeper parts of the basins. Towards the eastern part of the Danish Central Graben, close to the Coffee Soil Fault, the proportion of sandstones increases and there appears to be a transition locally to the sandy Poul Formation. 
G-1

Reference section: Farsund Formation
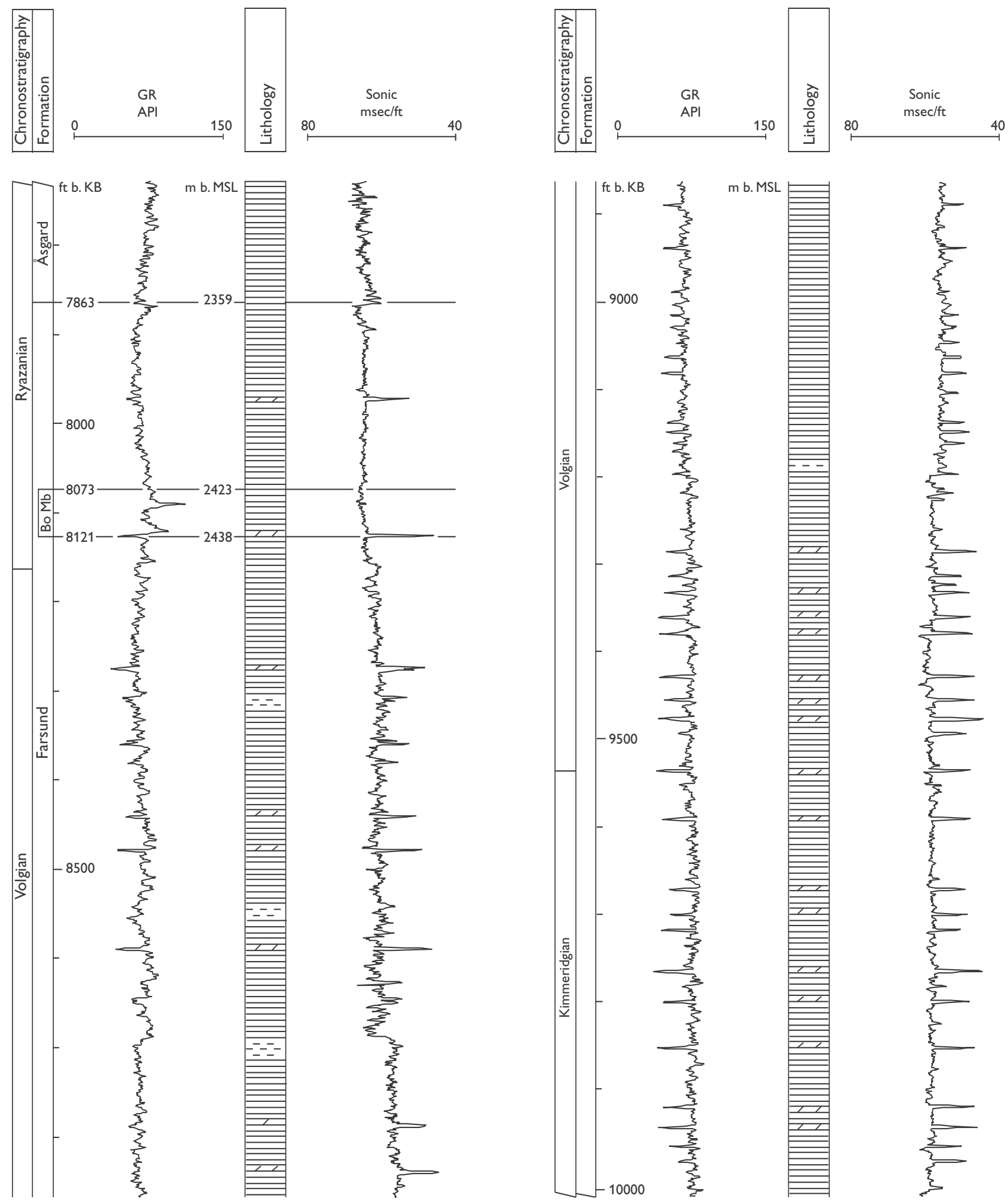

Fig. 26. The Farsund Formation in the G-1 well in the southern part of the Danish Central Graben, 3631-2359 $\mathrm{m}$ b. MSL, designated as the new reference section in the Danish sector. For legend, see Fig. 5. 

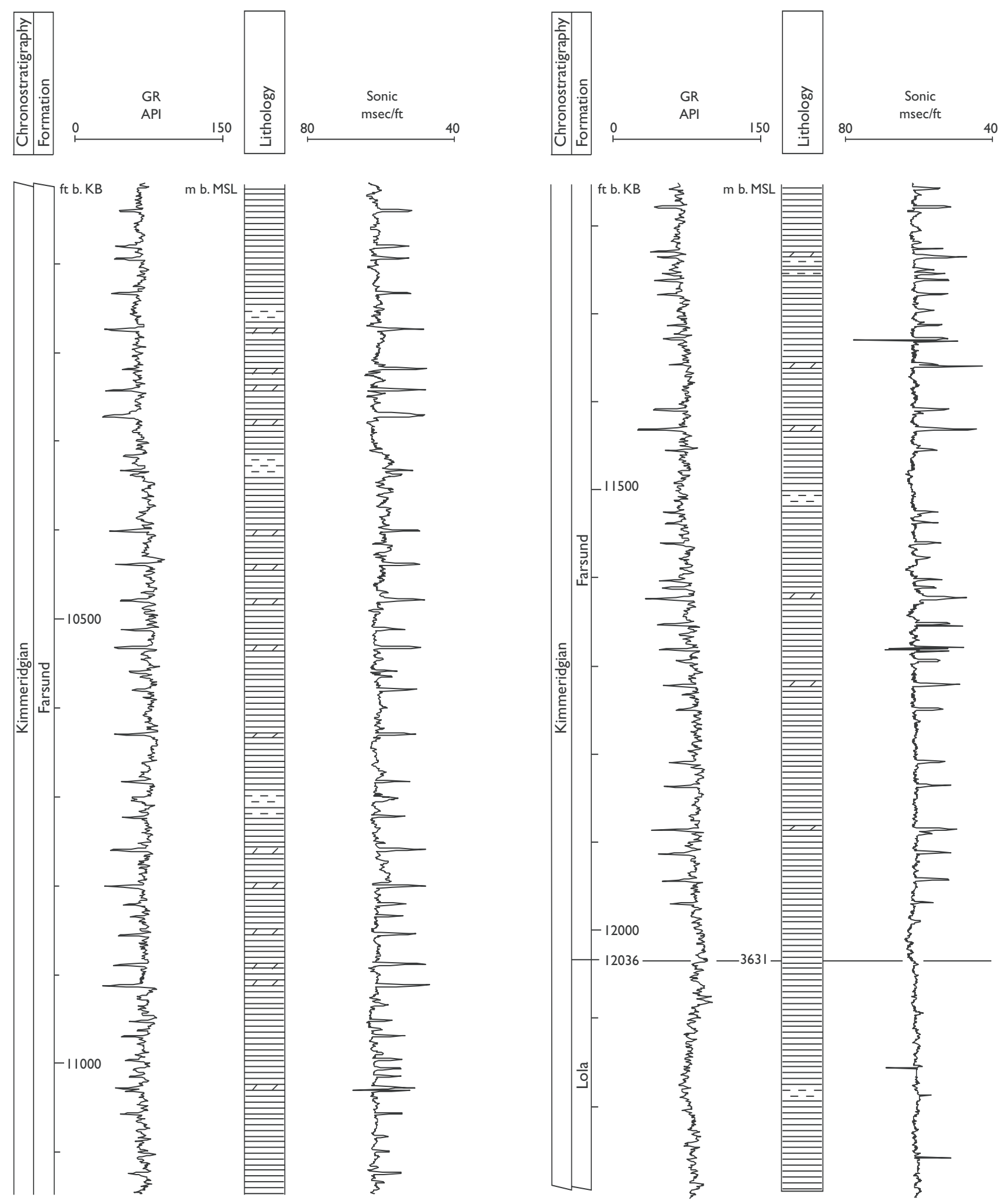


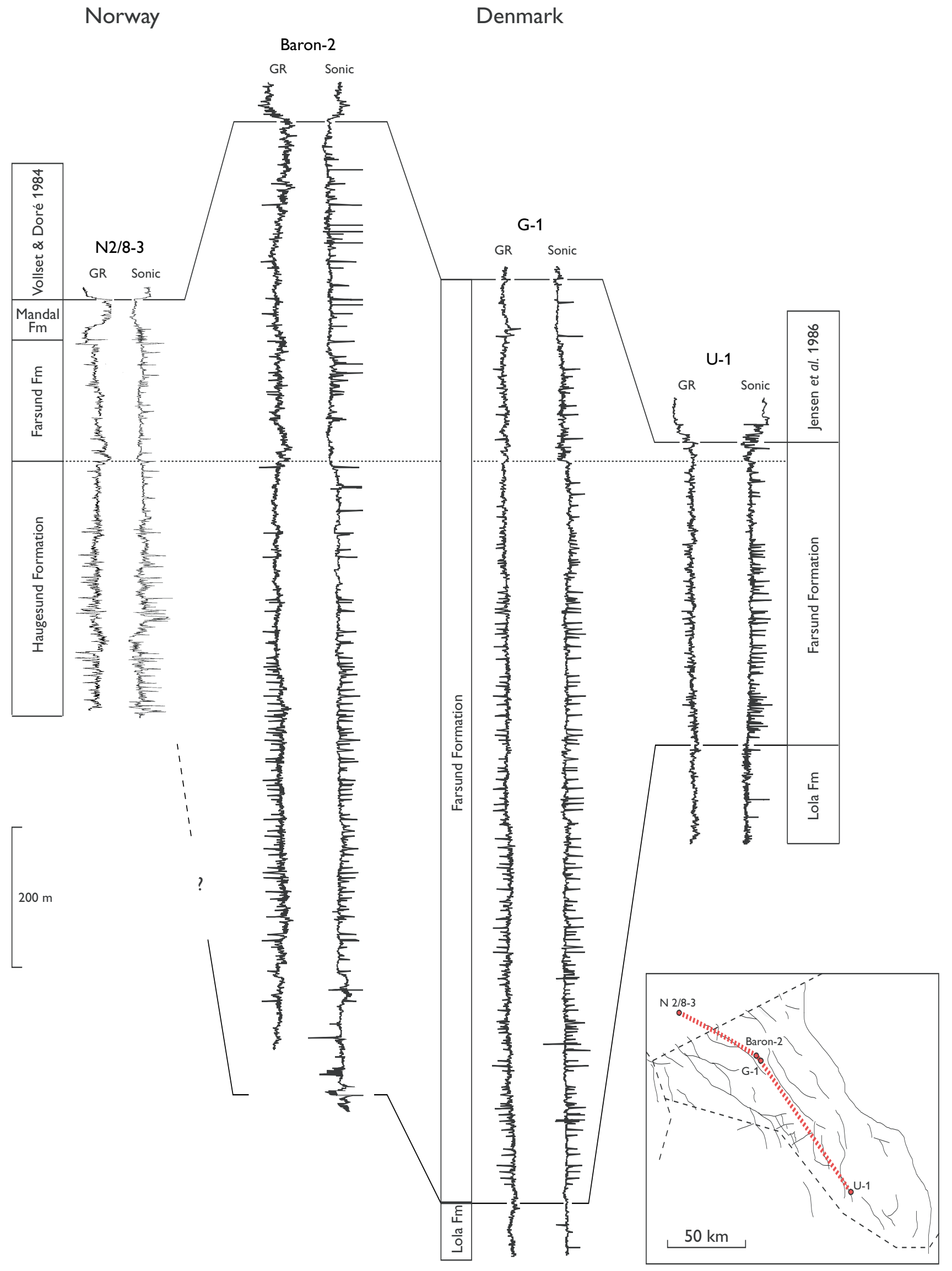


Log characteristics. The formation is characterised by relatively high gamma-ray values and relatively low sonic velocities. High velocity peaks and corresponding low gamma-ray readings reflecting dolomite or limestone beds or carbonate-cemented sandstone and siltstone beds are a common feature of the formation.

Boundaries. The Farsund Formation overlies the Lola Formation in most of the Danish Central Graben (Figs $26,27)$. On plateau areas in the western and northwestern part of the Danish Central Graben, the Farsund Formation overlies the Heno Formation (Figs 21-25). The boundary with the Lola Formation is defined above a velocity minimum and a corresponding gamma-ray maximum. Above the boundary, there is commonly a general increase in velocity, a decrease in gamma-ray values and a much higher frequency of sonic velocity peaks. The boundary with the Heno Formation is characterised by an abrupt or gradual increase in gammaray readings and a corresponding decrease in velocity.

The upper boundary with the Asgard Formation (Cromer Knoll Group) is placed at the first significant change from high gamma-ray and low sonic velocity readings of the Farsund Formation to the low gammaray values and higher sonic velocities of the Åsgard Formation (Figs 26-28).

Distribution and thickness. The formation extends from the Norwegian North Sea area, through the Danish Central Graben. Southwards it correlates with the upper part of the Kimmeridge Clay Formation in the Dutch North Sea area. Eastwards, the formation correlates with the Børglum Formation of the Norwegian-Danish Basin, although the transition zone has not yet been located. Maximum thicknesses of more than $3000 \mathrm{~m}$ occur in the Tail End Graben.

Age. The Farsund Formation is of Late Kimmeridgian Ryazanian age (Poulsen 1986; Heilmann-Clausen 1987; Andsbjerg \& Dybkjær 2003, this volume).

\section{Facing page:}

Fig. 27. Well-log panel from the Norwegian 2/8-3 well (Norwegian reference well of the Farsund Formation) through the Baron-2 well, the G-1 well (new Danish reference well of the Farsund Formation) and the U-1 well (previous Danish reference well of the Farsund Formation). Note the position of the basal boundary of the Farsund Formation as picked in the Norwegian reference well and in the Danish wells.
Subdivision. Organic-rich mudstones in the upper levels of the Farsund Formation, previously referred to informally as the 'hot unit', are herein defined as the Bo Member of the Farsund Formation. The remainder of the formation is not subdivided at the level of members.

\section{Bo Member}

new member

History. Jensen et al. (1986) described the 'hot unit' as an informal member of the Farsund Formation characterised by mudstones that display unusually high gamma-ray values. Correlatives at least in part are known from the Norwegian sector where they are referred to the Mandal Formation (Vollset \& Doré 1984), and from the Dutch sector where they form the Clay Deep Member of the Kimmeridge Clay Formation (van Adrichem Boogaert \& Kouwe 1994). However, both the Mandal Formation and the Clay Deep Member span a greater stratigraphic interval and include mudstones showing intermediate gamma-ray values beneath and above the 'hot unit' as described by Jensen et al. (1986). Use of the Mandal Formation in the Danish sector is considered impractical due to difficulties in recognising the lower boundary in many of the Danish wells. The 'hot unit' of Jensen et al. (1986) is thus retained and given formal status as the Bo Member of the Farsund Formation.

Name. The Bo Member is named after the Bo-1 well, located in the southern Tail End Graben where the member is well-developed.

Type section. The Danish Bo-1 well, 8561-8434 ft b. KB, 2576-2537 m b. MSL (Fig. 28).

Reference section. The Danish E-1 well, 9853-9771 ft b. KB, 2966-2940 m b. MSL (Ineson et al. 2003, this volume, fig. 6).

Lithology and environment. The member is dominated by black to dark grey-brown, laminated claystones, which are carbonaceous and slightly calcareous to noncalcareous. The total organic carbon content ranges from $3-8 \%$, locally attaining values of more than $15 \%$ (Ineson et al. 2003, this volume). The organic matter is mainly liptinitic. Thin beds of dolomite may occur. In the Jeppe- 1 core, the unit also includes thin sandstone-mudstone couplets up to $5 \mathrm{~cm}$ thick; log data 
Bo-1

Type section: Bo Member
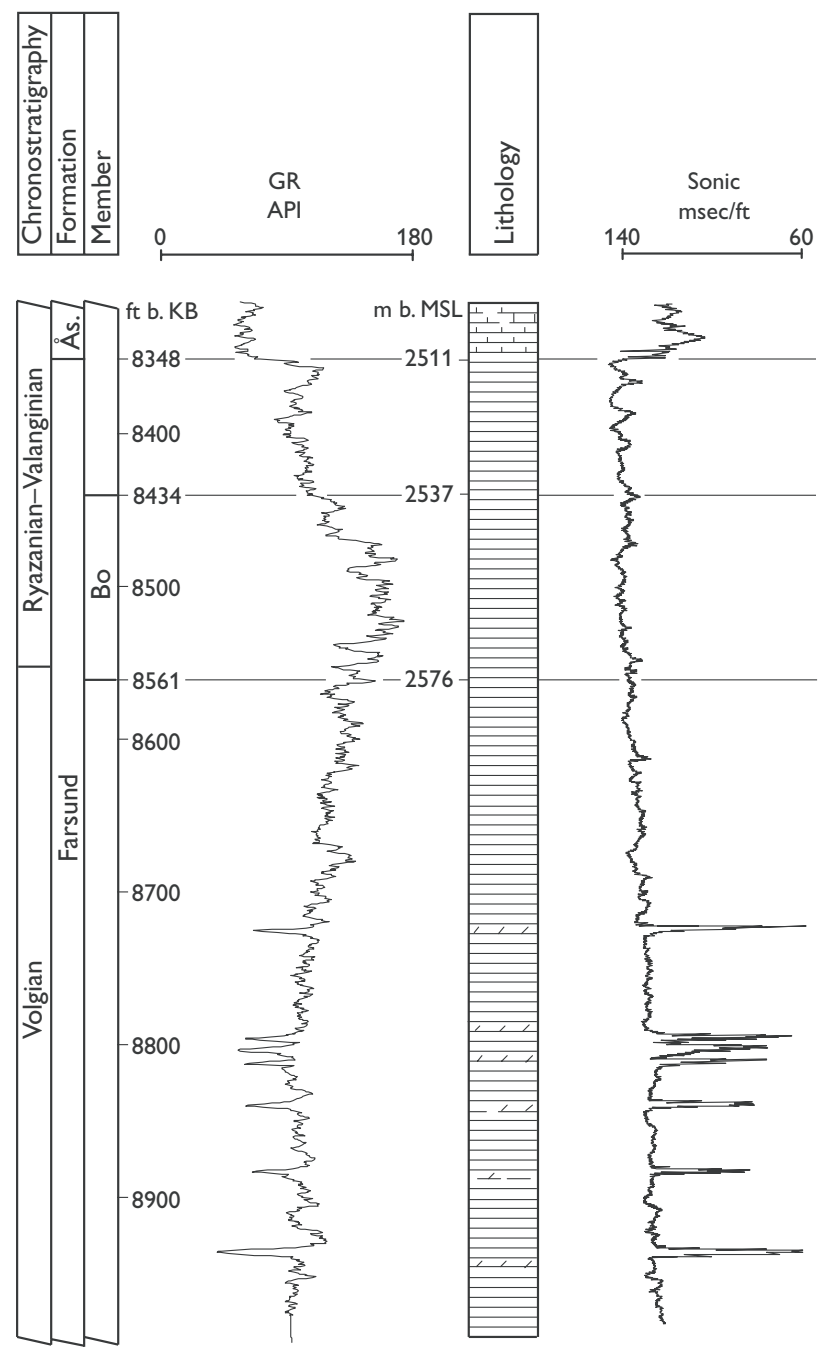

Fig. 28. Bo-1 well, located in the Danish Central Graben; type section of the new Bo Member (Farsund Formation), 2576-2537 m b. MSL. Ås., Åsgard. Modified from Jensen et al. (1986); for legend, see Fig. 5.

suggest that thicker sandstone-rich intervals are also present in the member (Ineson et al. 2003, this volume). Deposition occurred in a low-energy, oxygen-deficient deep marine environment. The sandstone-mudstone couplets were deposited from dilute turbidity currents (Ineson et al. 2003, this volume).

Log characteristics. The member is primarily identified by its high gamma-ray values, which are significantly higher than those of the underlying and overlying claystones of the Farsund Formation. The sonic velocity is low. The gamma-ray values may show significant vari-
V-1

Type section: Poul Formation
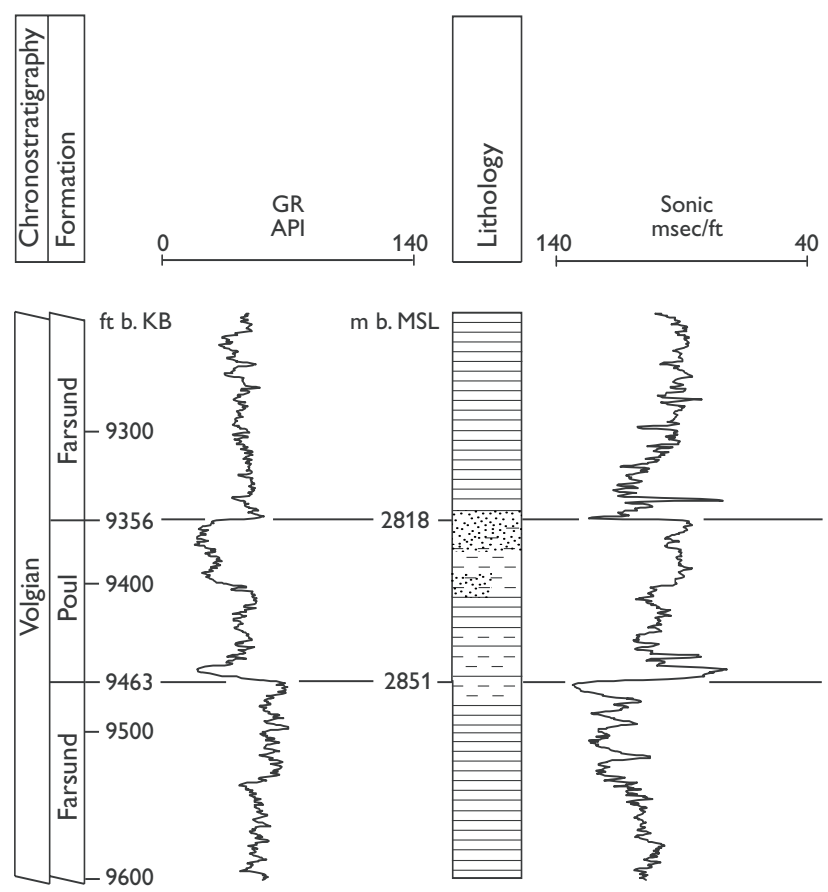

Fig. 29. V-1 well, located in the eastern part of the Danish Central Graben; type section for the Poul Formation, 2851-2818 m b. MSL. Modified from Jensen et al. (1986); for legend, see Fig. 5.

ation within the member with decreasing-upwards trends, 3-5 m thick, separated by intervals with more consistently high values (e.g. Bo-1).

Boundaries. The lower and upper boundaries are placed at shifts to the significantly lower gamma-ray values of the Farsund Formation.

Distribution and thickness. The member is recognised widely in the Danish Central Graben, where this portion of the Farsund Formation is preserved. On structural highs, the upper part of the Farsund Formation is commonly truncated and the member may be absent or reduced in thickness. The thickness varies greatly from less than $10 \mathrm{~m}$ in the southern Salt Dome Province to more than $100 \mathrm{~m}$ in the western part of the Danish Central Graben, probably controlled by local factors such as structural position and sediment supply (Ineson et al. 2003, this volume).

Age. Late Volgian - Late Ryazanian, mainly occurring within the Lower Ryazanian H. kochi Chronozone with 
a maximum age range from the C. preplicomphalus to the C. stenomphalus Chronozones (Birkelund et al. 1983; Poulsen 1992; Dybkjær 1998; Ineson et al. 2003, this volume).

\section{Poul Formation}

History. The Poul Formation was defined by Jensen et al. (1986).

Type section. The V-1 well, 9463-9356 ft b. KB, 2851-2818 $\mathrm{m}$ b. MSL, in the eastern part of the Danish Central Graben was selected by Jensen et al. (1986; Fig. 29).

Lithology and environment. The Poul Formation typically consists of dark grey siltstones and light grey, very fine-grained sandstones. The siltstones are partly argillaceous and grade into claystones. In the Ugle-1 well, located at the eastern margin of the Danish Central Graben close to the Coffee Soil Fault zone, the formation includes pebble conglomerates, coarse-grained sandstones and fine- to very fine-grained, silty sandstones. Shelly debris and lithic clasts are common, and the conglomerates may be polymictic. The clasts represent a wide range of lithologies suggesting a metamorphic source terrain with phyllites and other metasediments. Deposition was probably from turbidity currents on fault-bounded plateaus along the Coffee Soil Fault. The exceptionally thick and immature succession in the Ugle-1 well was probably deposited as a faultattached, localised slope apron.

Log characteristics. The Poul Formation is characterised by low gamma-ray values and intermediate sonic values representing silt- and sandstones, with a few peaks showing higher sonic velocities representing carbonatecemented beds.

Boundaries. The formation interfingers with the Farsund Formation, and the lower and upper boundaries are clearly defined at abrupt changes to lower gamma-ray values and higher sonic velocities than those that characterise the Farsund Formation.

Distribution and thickness. The formation is present in the Danish Central Graben close to the eastern faulted margin of the Central Graben. The thickest sandstone units occur on down-faulted plateaus along the Coffee Soil Fault zone. The maximum thickness of $175 \mathrm{~m}$ is observed in the Ugle-1 well (2591-2416 m b. MSL).
Age. The Poul Formation is of Volgian age (Hoelstad 1986b; Poulsen 1986).

\section{Stratigraphic evolution}

The Jurassic succession of Denmark, from Bornholm in the east to the Central Graben in the west, provides a detailed record of major basin evolutionary events that were experienced along the length of the Jurassic rift system. A summary of the Jurassic stratigraphic evolution of Denmark is given below; detailed accounts are presented elsewhere in this volume (Andsbjerg 2003, this volume; Andsbjerg \& Dybkjær 2003, this volume; Johannessen 2003, this volume; Nielsen 2003, this volume).

\section{Early Jurassic marine deposition}

The Early Jurassic transgression of the Danish Basin was initiated in the Norian (Late Triassic) and recorded by deposition of restricted marine claystones of the Vinding Formation and paralic - shallow marine sandstones and mudstones of the overlying and partly interfingering Gassum Formation. Mudstones of the Lower Jurassic Fjerritslev Formation conformably overlie the Gassum Formation over most of the Danish Basin and Sorgenfrei-Tornquist Zone, indicating a further deepening of the basin (Figs 30-32). The Fjerritslev Formation is subdivided into four members, all of which are present in the Danish Basin. The two sub-units of the lower member (F-Ia, F-Ib) are also recognised in the Danish Central Graben (Michelsen 1978b). The formation is patchily preserved in the southern part of the Norwegian North Sea sector and has been drilled in the Egersund Subbasin and in the area around the Southern Vestland Arch (Vollset \& Doré 1984). To the east, comparable mudstones have been exposed at Gantofta, Skåne, where they are referred to the Pankarp Member of the Rya Formation (Fig. 2; Frandsen \& Surlyk 2003, this volume). The Fjerritslev Formation was probably deposited over most of the south-eastern North Sea. The isolated occurrences of the formation are erosional outliers of a previously widely distributed Lower Jurassic cover, which existed prior to early Middle Jurassic uplift and erosion of the mid North Sea dome and the Ringkøbing-Fyn High (Michelsen 1978a, b; Gowers \& Sæbøe 1985; Ziegler 1990; Underhill \& Partington 1993; Andsbjerg \& Dybkjær 2003, this volume; Nielsen 2003, this volume). 


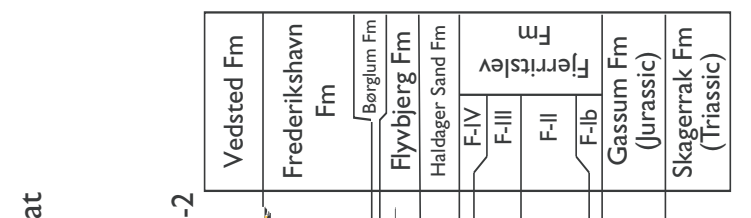

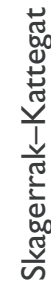

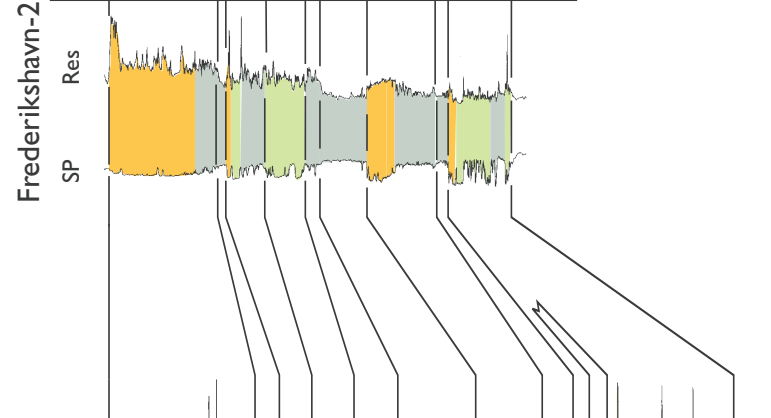

I.

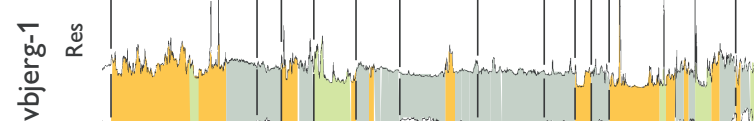

竞

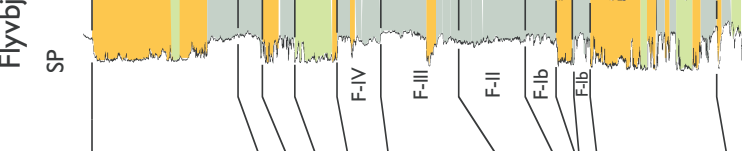

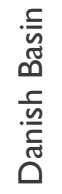
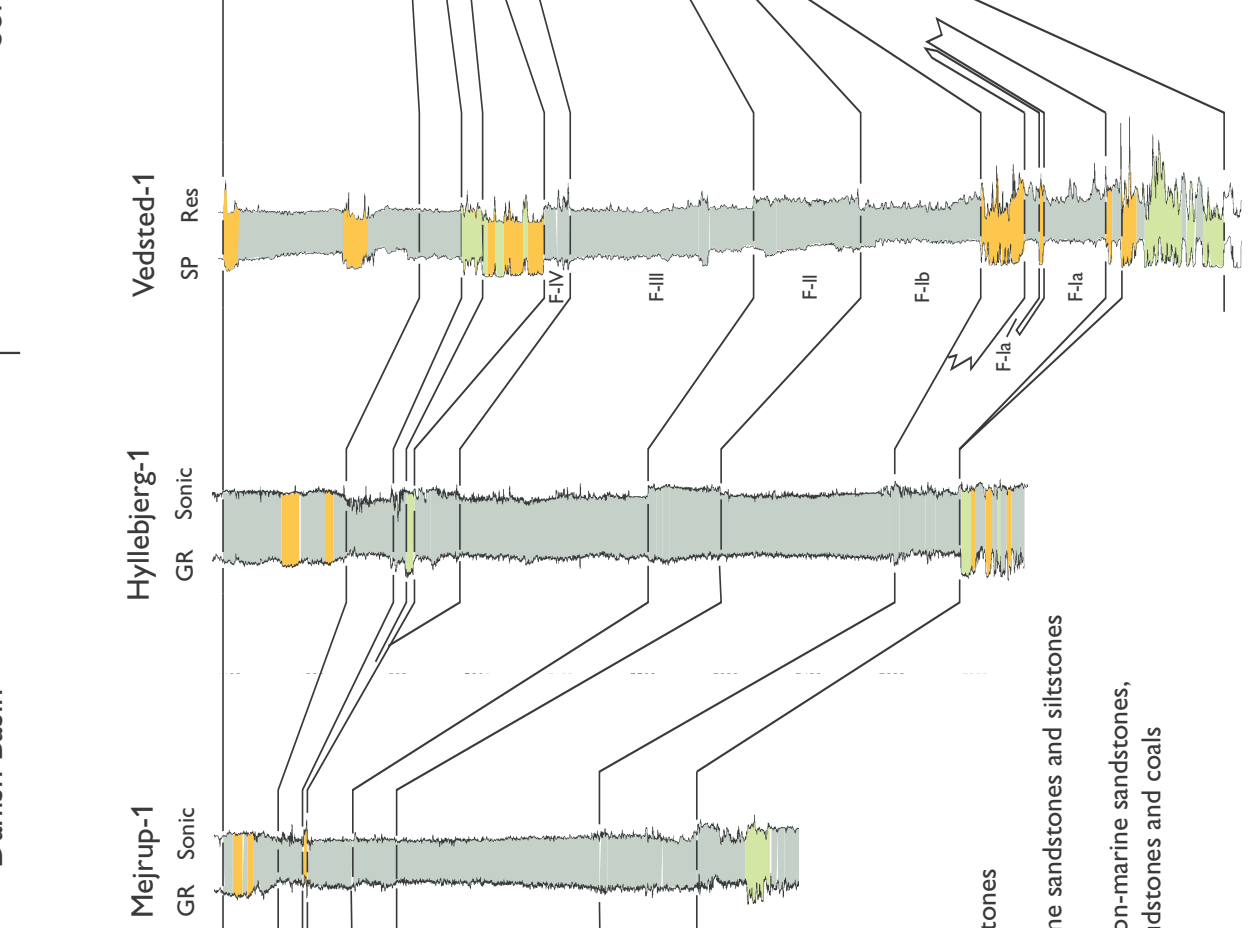

$\stackrel{\overbrace{}}{\Xi}$

疍

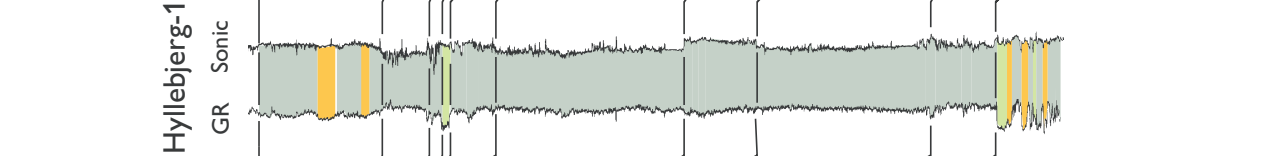




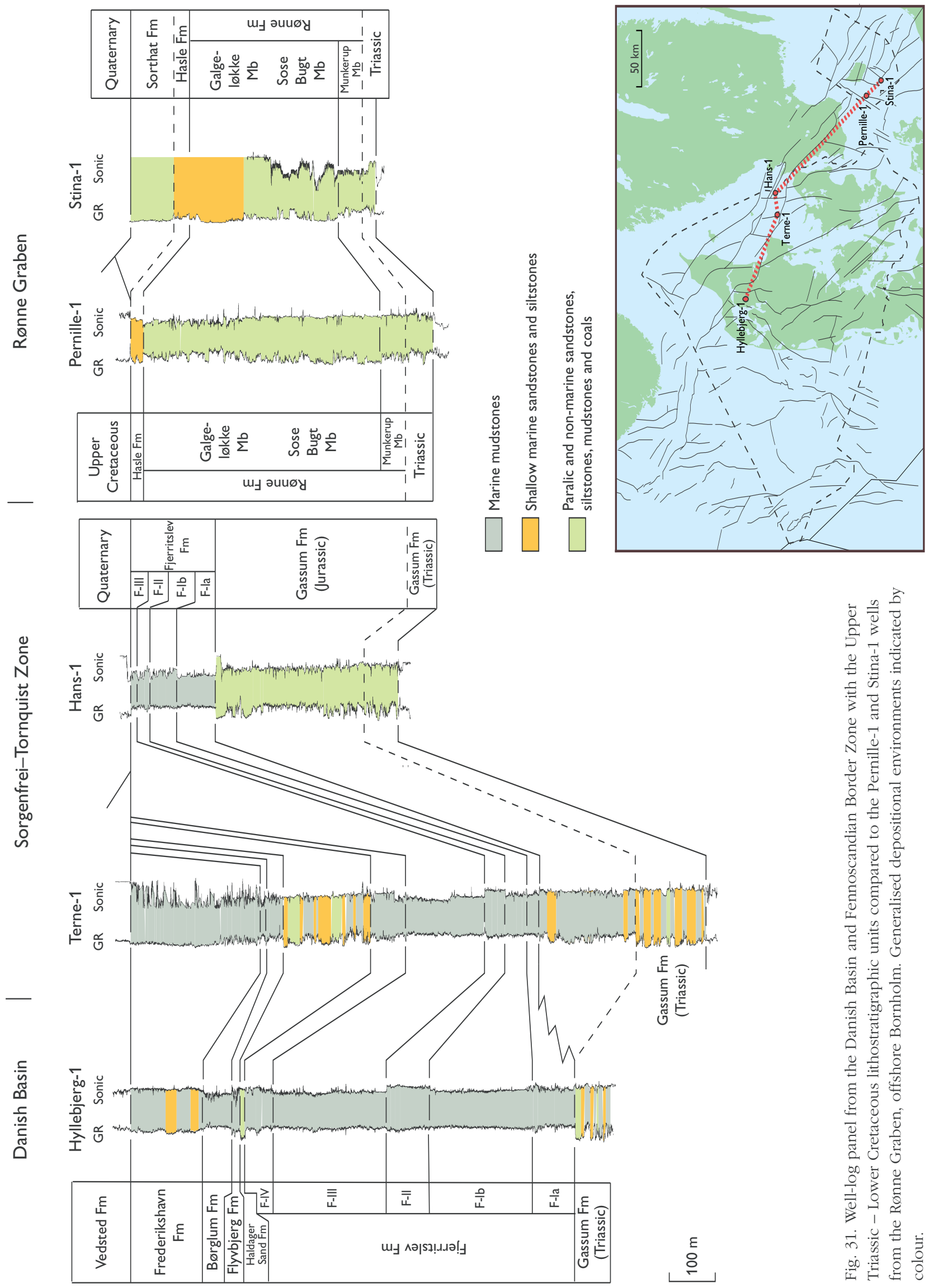


The Early Jurassic transgression resulted in the establishment of a well-oxygenated marine environment in the Danish Basin and in the central North Sea Basin (Fig. 33; Michelsen 1975, 1978a; Pedersen 1986). Marine claystones interbedded with thin sandstone beds and carbonate-cemented beds (F-Ia unit) are known from both areas. Along the north-eastern margin of the Danish Basin, fluvial and shallow marine conditions prevailed in the Hettangian - Early Sinemurian, and a stepwise backstepping of the sandy Gassum Formation took place (Figs 30-32; Nielsen 2003, this volume). In Skåne, southern Sweden, the Hälsingborg and Döshult Members represent a transition from deltaic to shallow marine conditions (Sivhed 1984; Erlström et al. 1999; Ahlberg et al. 2003, this volume). On Bornholm, an overall transgressive succession of lacustrine, coastal plain and tidal flat deposits is represented by the Rønne Formation, which is thickly preserved in the Rønne Graben (onshore: Galgeløkke-1, -2; offshore: Pernille-1, Stina-1; Figs 5, 31; Gravesen et al. 1982; Nielsen 1995; Surlyk et al. 1995).

The depositional environment changed in the Early Sinemurian due to continued sea-level rise. Deposition of fine-grained claystones (F-Ib unit) took place from the Early Sinemurian to the earliest Early Pliensbachian in the basinal areas. To the north, in Jylland, the Gassum Formation was overstepped, and deposition of marine clay (F-Ib unit) extended onto the Skagerrak-Kattegat Platform (Fig. 30). Deposition of fluvial and shallow marine sandy deposits of the Döshult Formation in Skåne was followed by deposition of marine clays of the Pankarp Member, whereas shallow marine sand, tidal flat heteroliths and estuarine mud are found in the correlative part of the Rønne Formation on Bornholm (Surlyk et al. 1995; Erlström et al. 1999; Frandsen \& Surlyk 2003, this volume; Nielsen 2003, this volume). Continued sea-level rise in the Early Pliensbachian led to open marine conditions and deposition of silty clay (F-II member) in the Danish Basin and more sandy deposits on the Skagerrak-Kattegat Platform (Fig. 30). Farther to the east and south-east, in the Fennoscandian Border Zone, marine sand and clay (Katlösa Member in Skåne) and marine sand and silt (Hasle Formation on Bornholm) were deposited (Troedsson 1951; Surlyk \& Noe-Nygaard 1986; Norling et al. 1993; Frandsen \& Surlyk 2003, this volume; Nielsen 2003, this volume).

After a regressive event with deposition of minor sands and erosion on the Skagerrak-Kattegat Platform, deposition of clay again dominated in the Danish Basin (F-III member) in Late Pliensbachian - Early Toarcian times (Fig. 30). At the end of the Pliensbachian, the benthic faunas disappeared due to increasing anoxia, prob- ably related to a sea-level rise, corroborated by sedimentology, organic geochemical analyses and palynology (Pedersen 1986; Michelsen 1989b; Dybkjær 1991; Nielsen 2003, this volume). The sea-level rise culminated in the Early Toarcian. Towards the end of the Toarcian, a regression began with deposition of interbedded clay and sand (F-IV Member) in a more shallow and restricted marine environment (Figs 30, 31).

A regressive tendency also occurred further south in the Fennoscandian Border Zone during the Late Pliensbachian as reflected by dark grey, grey-green and red-brown marine sandstones and siltstones (Rydebäck Member) in Skåne. The benthic foraminiferal fauna decreased markedly in density and diversity from the Pliensbachian to the Toarcian, but ammonites occur throughout the formation (Norling 1972). On Bornholm, sandy and clayey deposits interbedded with thin coal beds (the Sorthat Formation) were deposited in brackish coastal plain environments (Koppelhus \& Nielsen 1994; Petersen \& Nielsen 1995; Petersen et al. 2003b, this volume).

The Lower-Middle Jurassic boundary is difficult to identify in the Danish Basin due to relatively poor biostratigraphic data and is conventionally placed between the Fjerritslev and Haldager Sand Formations (Michelsen 1978a, 1989a). Recent studies indicate that the LowerMiddle Jurassic transition is situated within the uppermost part of the Fjerritslev Formation in the Sorgenfrei-Tornquist Zone; elsewhere, it coincides with the marked erosion surface between the Fjerritslev and Haldager Sand Formations (Nielsen 2003, this volume). The maximum thicknesses of the uppermost member (F-IV) of the Lower Jurassic Fjerritslev Formation and the Middle Jurassic Haldager Sand Formation are found in the Sorgenfrei-Tornquist Zone, indicating continuous subsidence contemporaneously with the Middle Jurassic uplift of the Ringkøbing-Fyn High (Michelsen \& Nielsen 1991; Nielsen 1992, 1994, 2003, this volume).

The gradual eastwards transgression during the Early Jurassic known from the Fennoscandian Border Zone is also recorded in north-eastern Germany (Meinhold et al. 1960; Bertelsen 1978; Michelsen 1978a). To the south-west, in the Dutch Central Graben, a continuous succession of Lower-Middle Jurassic deposits is included in the Altena Group, comprising the Aalburg, Posidonia Shale and Werkendam Formations (Fig. 34; NAM \& RGD 1980; van Adrichem Boogaert \& Kouwe 1994; Herngreen et al. 2003, this volume). The overall lithology of the Altena Group is similar to that of the Fjerritslev Formation. The Aalburg Formation is of HettangianPliensbachian age, and the sediments seem to have 


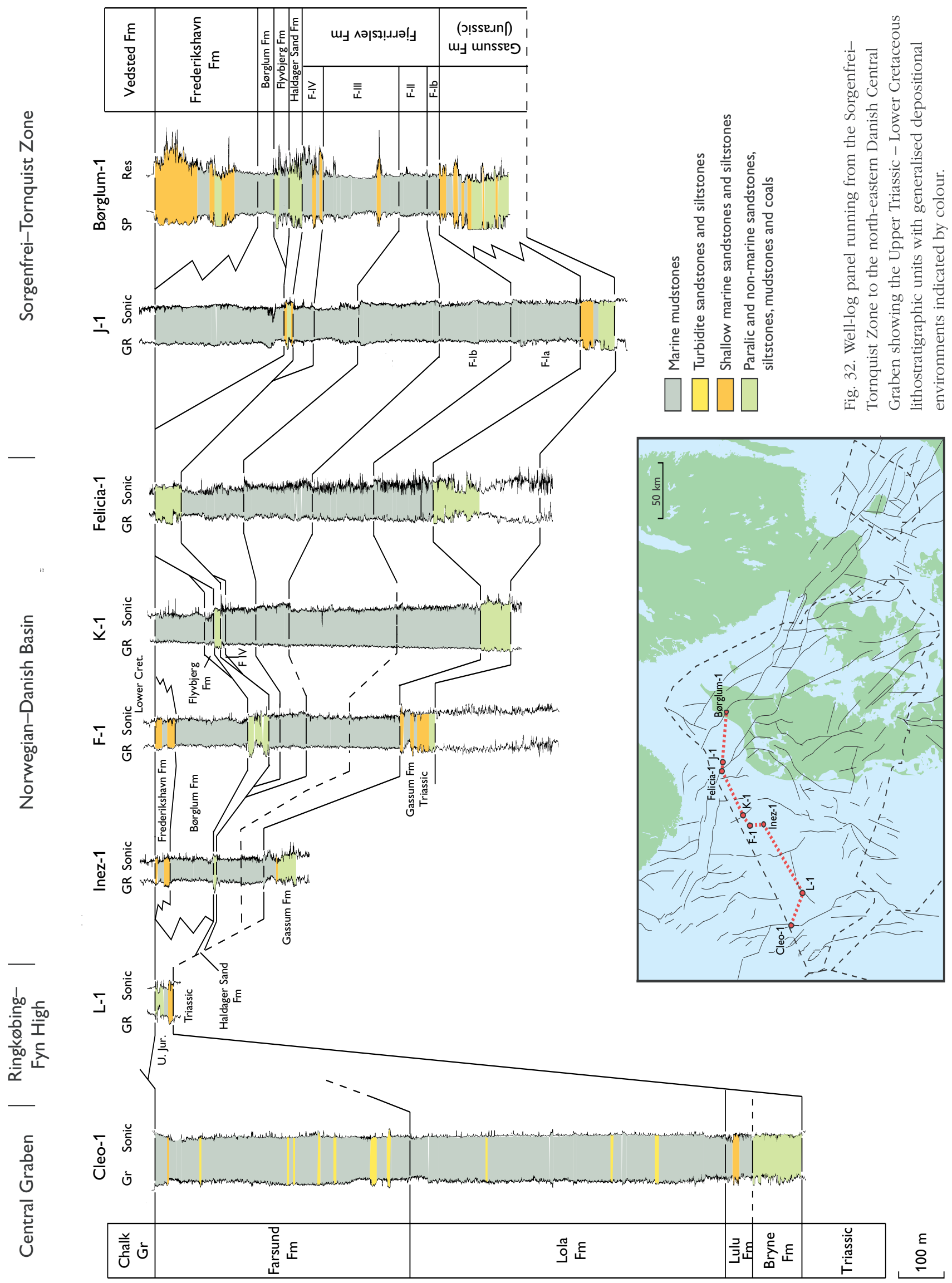



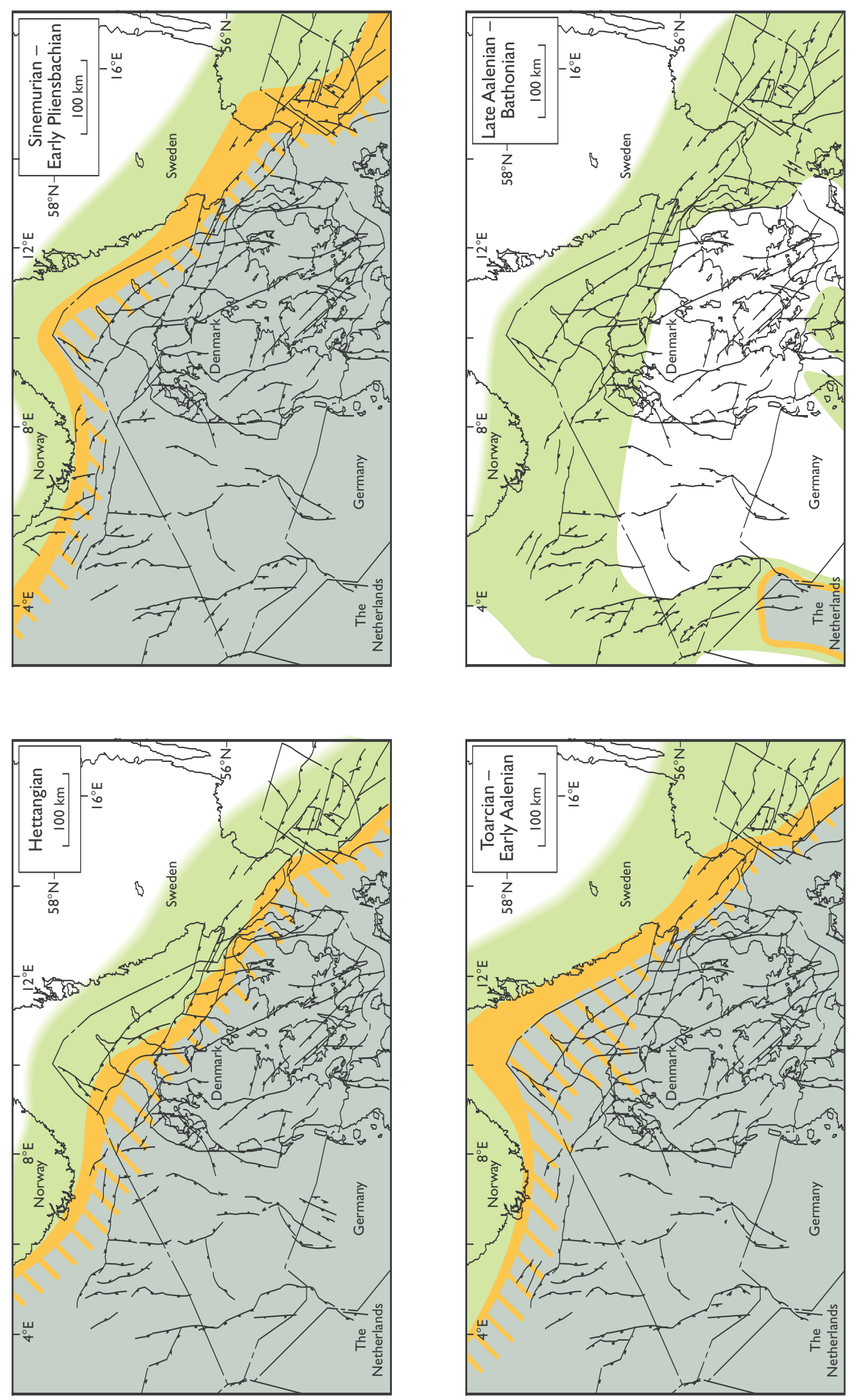

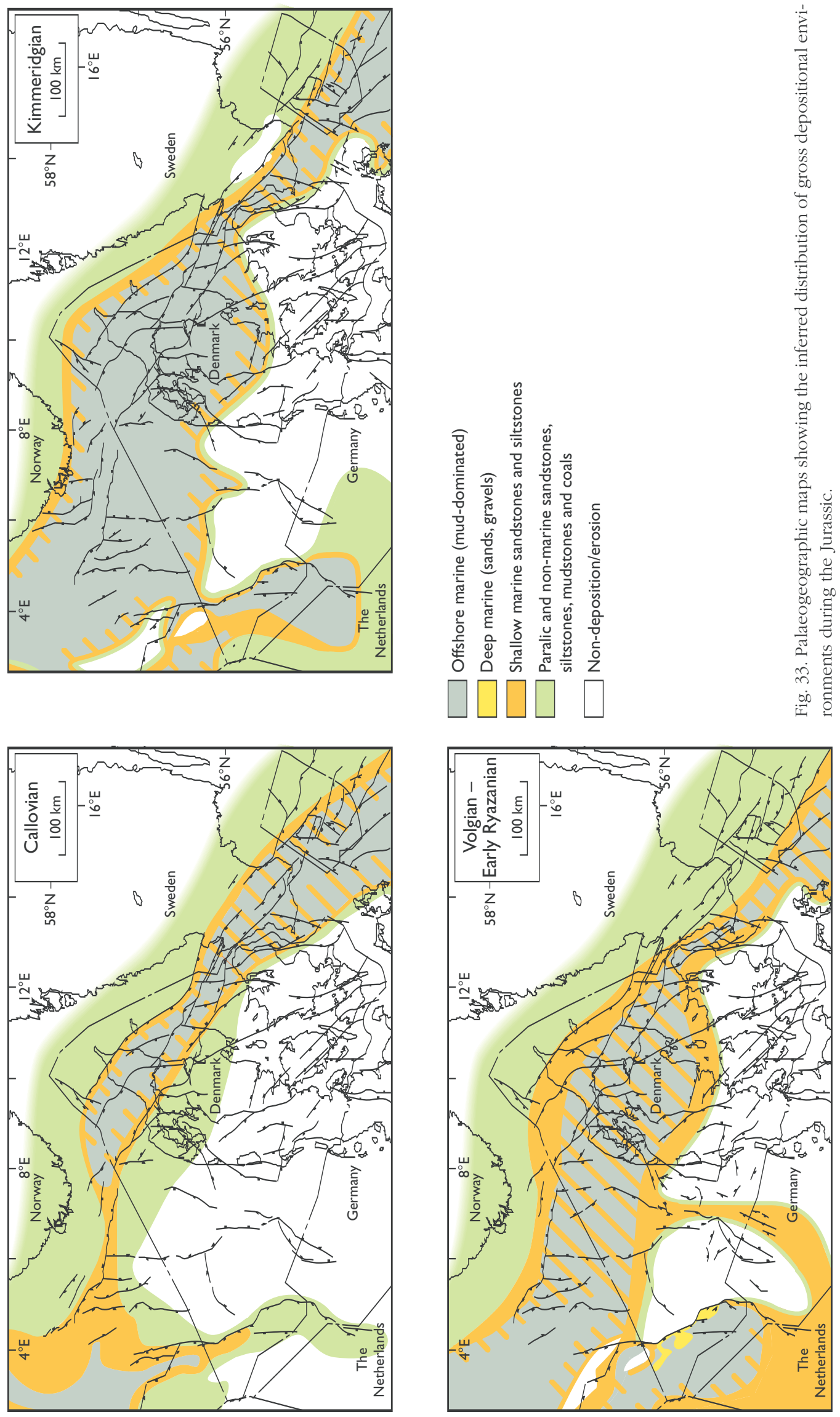
been deposited in a lower shoreface to deep offshore environment similar to that of the lower Fjerritslev Formation. The Posidonia Shale Formation is of Early Toarcian age and seems to have been deposited under dysoxic conditions as were the upper part of the F-III and the lower part of the F-IV members of the Fjerritslev Formation. The Werkendam Formation was deposited in a shallow, open marine environment during Late Toarcian - earliest Bathonian times.

\section{Middle Jurassic uplift}

During Late Aalenian - Early Bajocian times, the central North Sea area including the Ringkøbing-Fyn High became uplifted and formed a broad arch (Michelsen 1978a; Koch 1983; Ziegler 1990; Andsbjerg et al. 2001; Nielsen 2003, this volume) rather than a dome as suggested by Underhill \& Partington (1993, 1994). The uplift influenced a large area from England to Denmark and widespread erosion occurred. The SorgenfreiTornquist Zone seems to have been mainly unaffected by uplift and erosion, but farther south and south-westwards in the Danish Basin, erosion cut deeply into the Fjerritslev Formation and totally removed these strata from the Ringkøbing-Fyn High (Michelsen 1978a; Koch 1983; Nielsen 2003, this volume). On the eastern part of the Ringkøbing-Fyn High, erosion also removed the upper part of the Triassic succession, and Triassic sediments are absent from the western part of the high.

The main rifting of the Central Graben was initiated during the Middle Jurassic subsequent to the uplift of the central North Sea (Fig. 33). Down-faulting took place along the eastern bounding Coffee Soil Fault leading to preservation of Lower Jurassic deposits in the south-eastern part of the Danish Central Graben. Erosion cut deeply into the pre-Jurassic deposits in the north-western part of the Central Graben due to simultaneous half-graben tilting, and Permian and Carboniferous rocks subcrop postLower Jurassic deposits in this area (Fig. 35).

Middle Jurassic block-faulting and subsidence characterised the Sorgenfrei-Tornquist Zone, where the entire Lower Jurassic - lowermost Middle Jurassic succession is preserved (Michelsen \& Nielsen 1991; Nielsen 2003, this volume).

The regional uplift also affected Skåne where renewed faulting and local uplift accompanied by volcanism clearly influenced sedimentation in Middle Jurassic time by reducing the depositional area to a narrow basin (Klingspor 1976; Rolle et al. 1979; Norling \& Bergström 1987; Norling et al. 1993; Ahlberg et al. 2003, this volume).

\section{Middle Jurassic fluvial and paralic deposition}

The early Middle Jurassic regional uplift of the central North Sea Basin resulted in radical palaeogeographic changes, including closure of the seaway linking the Arctic Sea with the Tethys Ocean. In the Danish area, subsequent rifting changed the basin configuration from the extensive Early Jurassic sea into two fault-controlled zones of deposition, the Central Graben and the Danish Basin where a depocentre was situated in the SorgenfreiTornquist Zone (Fig. 33; Andsbjerg et al. 2001). Regional and local erosion cut deep into the Lower Jurassic and older deposits. The erosional surface was onlapped by fluvial, paralic and marine sediments during Middle-Late Jurassic times owing to renewed regional subsidence (Andsbjerg \& Dybkjær 2003, this volume; Johannessen 2003, this volume; Nielsen 2003, this volume).

Middle Jurassic deposits occur in the central and north-eastern parts of the Danish Basin. There is a marked unconformity between the marine claystones of the Lower Jurassic Fjerritslev Formation and the fluvial to shallow marine sandstones of the Middle Jurassic Haldager Sand Formation. In the fault-bounded Sorgenfrei-Tornquist Zone, the boundary between the formations occurs in the Lower Aalenian and is developed as a marine regressive erosion surface (Poulsen 1996; Nielsen 2003, this volume). The main change in palaeogeography involving uplift, regression and influx of sand thus seems to have occurred in the Early Aalenian.

Subsequent to the uplift event, a Middle Jurassic succession, more than $150 \mathrm{~m}$ thick, accumulated in the Sorgenfrei-Tornquist Zone; this succession comprises fine- to coarse-grained, shallow marine sandstones and fluvial sandstones and siltstones interbedded with marine and lagoonal claystones and thin coal beds (Haldager Sand Formation, Figs 30-32). This succession thins to

\section{Facing page:}

Fig. 34. Comparison of the Upper Triassic - Lower Cretaceous lithostratigraphic schemes from the North Sea Central Graben, the Norwegian-Danish Basin and the Fennoscandian Border Zone. Sst., Sandstone; M.W.Mb, Middle Werkendam Member; M.G.Mb, Middle Graben Sandstone Member; U.G., Upper Graben Formation. Modified from Bertelsen (1978, 1980); Michelsen (1978, 1989a); NAM \& RGD (1980); Gravesen et al. (1982); Sivhed (1984); Vollset \& Doré (1984); Herngreen \& Wong (1989); Norling et al. (1993); Richards et al. (1993); van Adrichem Boogaert \& Kouwe (1994); Koppelhus \& Nielsen (1994); Ahlberg et al. (2003, this volume); Herngreen et al. (2003, this volume). 


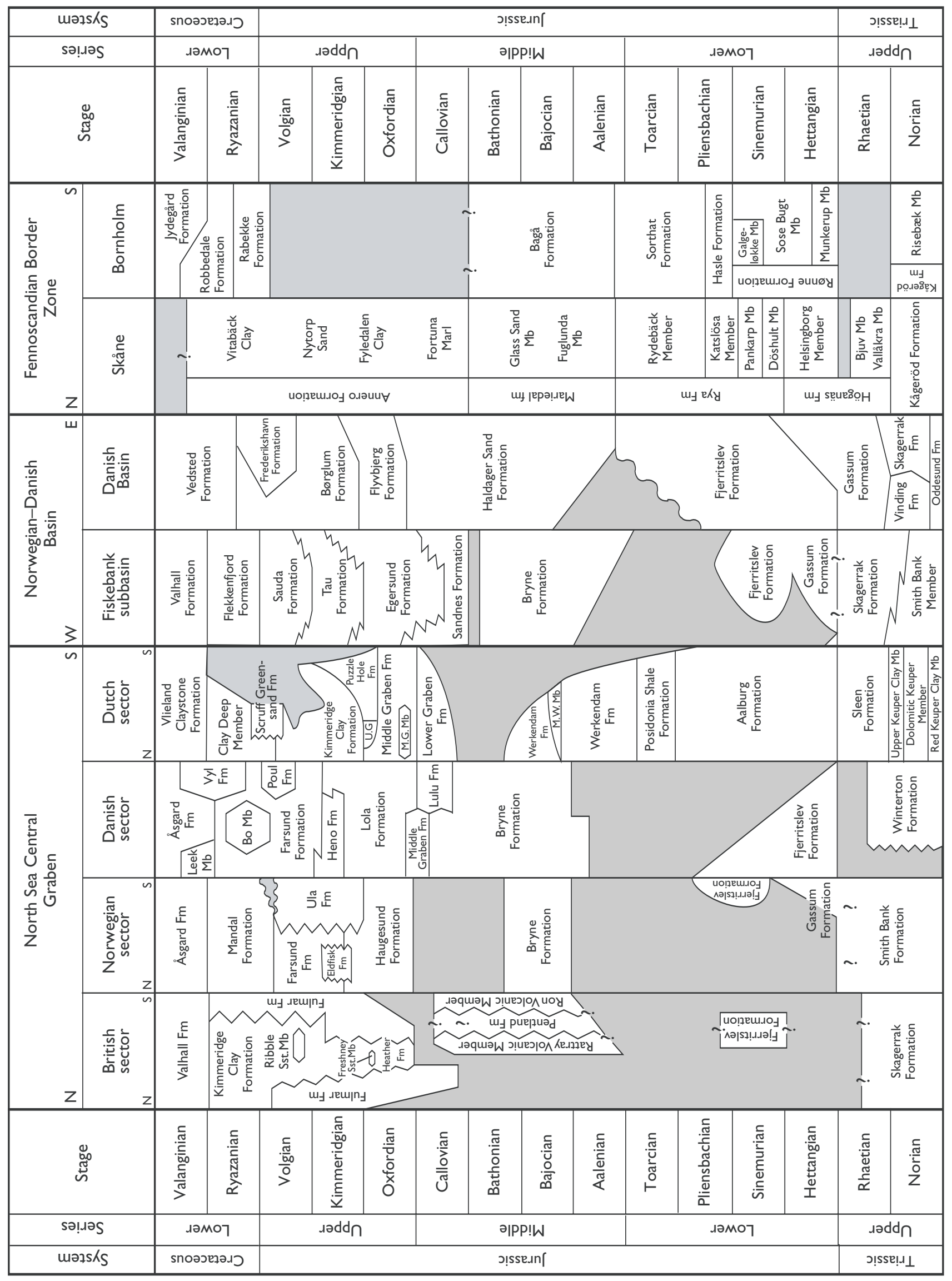




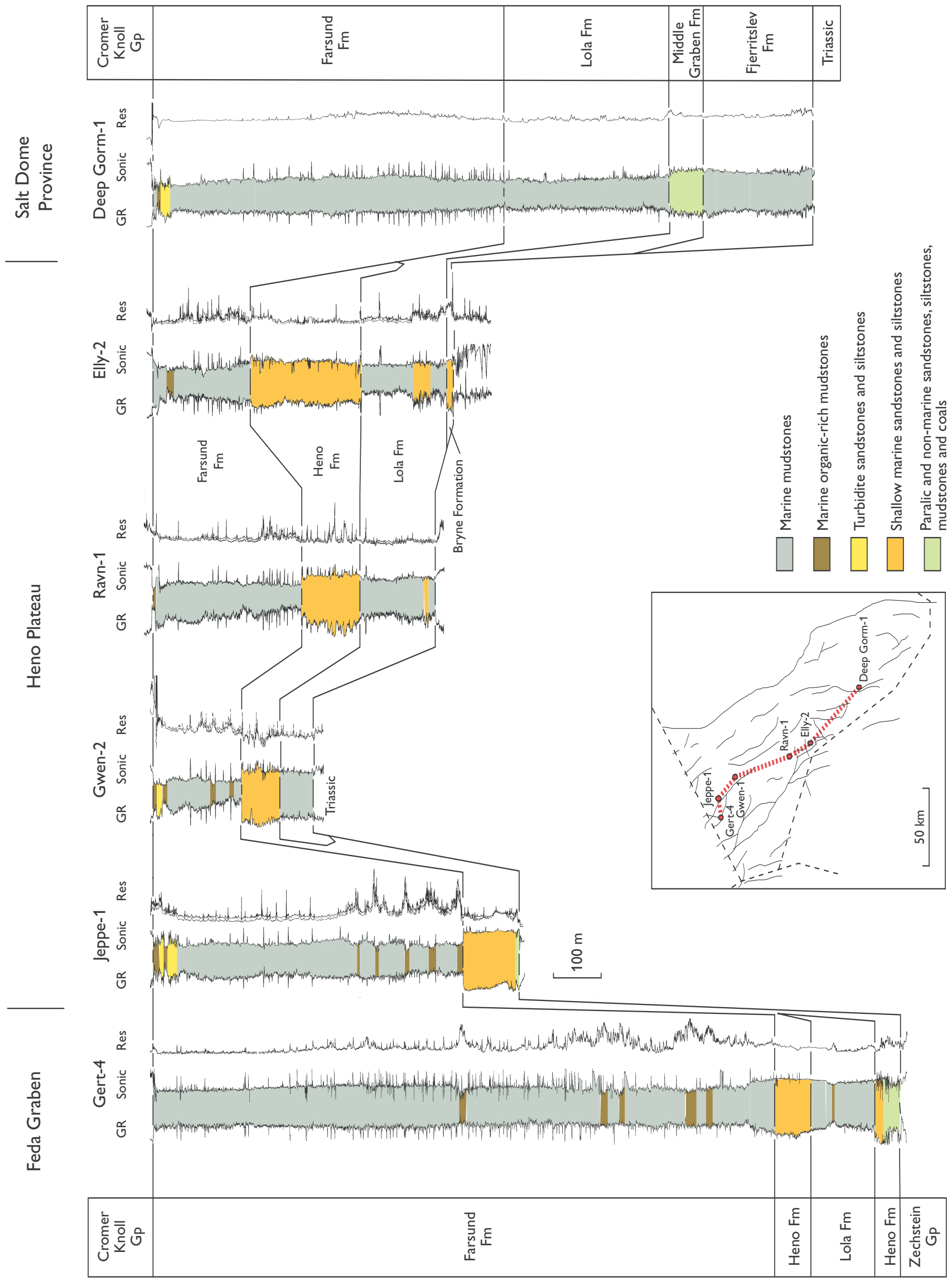


less than $10 \mathrm{~m}$ in central and south-western parts of the Danish Basin. On the Skagerrak-Kattegat Platform, north-east of the Sorgenfrei-Tornquist Zone, the thickness of the Haldager Sand Formation varies between $40 \mathrm{~m}$ and $90 \mathrm{~m}$. A braided river system running downslope from the uplifted Ringkøbing-Fyn High has been suggested as the main method of transport for the sediments (Koch 1983). The Middle Jurassic deposits are generally poor in fossils, but palynological assemblages suggest an Aalenian-Callovian age (reviewed by Nielsen 2003, this volume). Dinoflagellate cysts from the top part of the Haldager Sand Formation in the Vedsted-1 well section indicate a Late Callovian or younger age (Poulsen 1992, 1996), suggesting that the youngest sediments of the Haldager Sand Formation in the Sorgenfrei-Tornquist Zone were deposited during a Callovian sea-level rise.

In the north-western part of the Norwegian-Danish Basin and in the Central Graben, sediments equivalent to the Haldager Sand Formation are referred to the fluvio-deltaic Bryne Formation. To the south-east, along the Fennoscandian Border Zone in Skåne, southern Sweden, the development corresponds to that of the Sorgenfrei-Tornquist Zone in the Danish area. A change from the marine Rydebäck Formation to fluvial, lacustrine, lagoonal and shallow marine deposits of the Fuglunda Beds (Mariedal formation) and the Vilhelmsfält Formation (Ahlberg et al. 2003, this volume) took place in the late Aalenian, and deltaic deposition seems to have continued throughout the Bathonian (Figs 2, 33 , 34). The Aalenian part of the Rydebäck Formation consists of black and variegated siltstones with a varying clay content showing a general regressive tendency, and the foraminiferal fauna is sparse compared to that of the underlying Lower Jurassic succession (Norling 1972). Several conglomeratic horizons suggest breaks in marine deposition (Norling et al. 1993). The Fuglunda

\section{Facing page:}

Fig. 35. NW-SE well-log panel through the Danish Central Graben showing the Upper Triassic - Lower Cretaceous lithostratigraphic units with generalised depositional environments indicated by colour. Note the organic-rich mudstones, locally associated with turbidite sandstones, in the uppermost Farsund Formation of these wells (excluding Gert-4); these are referred to the Bo Member (see above and Ineson et al. 2003, this volume). Lower Cretaceous strata of the Cromer Knoll Group cap the Farsund Formation in this transect with the exception of the Elly-2 well in which the Farsund Formation is unconformably overlain by the Upper Cretaceous Chalk Group.
Beds consist of alternating sand and clay with thin coal beds. Deposition of clean sand, probably of shallow marine origin (the Glass Sand Member of the Mariedal formation), took place during most of the Bathonian. The clay-dominated, marine Fortuna Marl was deposited in the southern part of Skåne from latest Bathonian time, throughout the Callovian and into the Early Oxfordian (Norling 1972). Marine influence in the Middle Jurassic thus seems to have increased south-eastwards along the Fennoscandian Border Zone (Fig. 2).

On Bornholm, an erosional unconformity between the Sorthat and Bagå Formations separates Lower Jurassic paralic deposits from Middle Jurassic fluvial and lacustrine deposits (Koppelhus \& Nielsen 1994). The Middle Jurassic deposits consist of fluvial sand and gravel and lacustrine clay with coal beds deposited during Late Aalenian(?) and Bajocian-Bathonian times. Locally, the succession contains debris flow deposits indicating movements on the eastern bounding fault of the Rønne Graben in Bathonian time (Gry 1969). The top of the Baga Formation is an erosional unconformity that forms the present-day land surface, and Callovian and Upper Jurassic strata are absent on Bornholm, although the lowermost deposits of the Rabekke Formation in the Nyker Fault Block may extend down into the Volgian (Gravesen et al. 1982).

In the Danish Central Graben, Middle Jurassic deposition took place in the down-faulted area west of the Coffee Soil Fault zone. Sandstones with subordinate siltstones and claystones, and laterally extensive coal beds in the upper part of the succession, characterise the Middle Jurassic Bryne and Lulu Formations in the northern Danish Central Graben (Fig. 36). An upwards increase in marine influence is reflected by a change from fluvial or coastal plain deposits in the lower part to marginal and shallow marine deposits in the upper part of the succession (Johannessen \& Andsbjerg 1993; Andsbjerg 2003, this volume).

In the southern Danish Central Graben, the lower part of the Middle Jurassic succession is characterised by thick sandy deposits interbedded with silt- and claystones and occasional thin coal beds (Bryne Formation). The upper part contains claystones, siltstones and common coal beds (Middle Graben Formation; Figs 35, 36). The depositional environment evolved from a coastal plain environment with strong fluvial influence to a lowenergy paralic environment dominated by lagoons or interdistributary bays.

The environmental evolution through Middle Jurassic time shows an increasing marine influence culminating in the major Late Jurassic marine transgression, which 


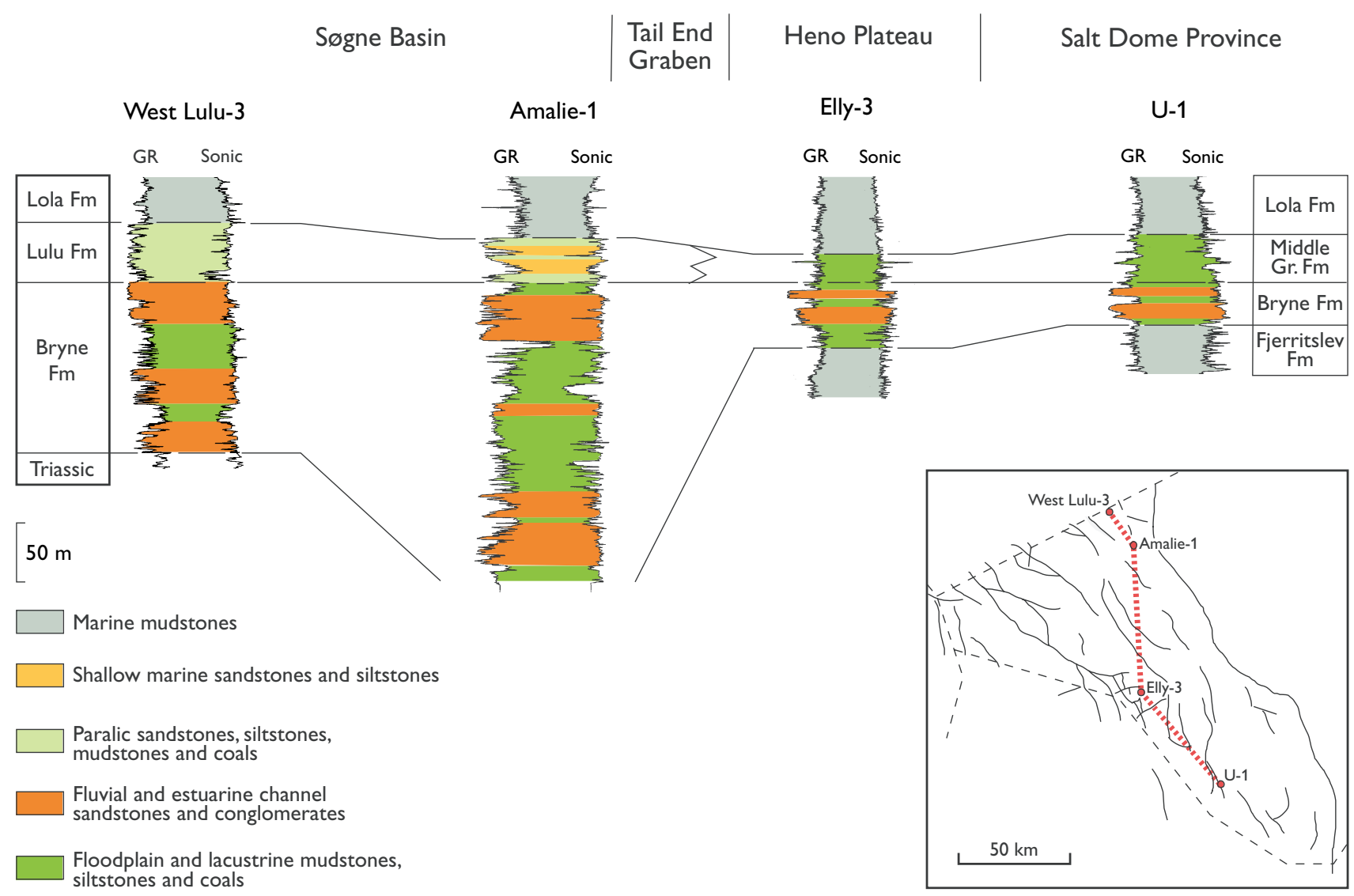

Fig. 36. North to south well-log panel through the Danish Central Graben showing the Middle - lower Upper Jurassic lithostratigraphic units with generalised depositional environments indicated by colour.

led to deposition of deep offshore clay-dominated deposits. The facies and age distribution of the Middle Jurassic deposits recognised in Central Graben well sections from the Norwegian, Danish and Dutch sectors indicate that the transgression came from the north (Michelsen et al. 1987; Johannessen \& Andsbjerg 1993; Underhill \& Partington 1994). In the Norwegian Fiskebank Subbasin and the Norwegian sector of the Central Graben, the non-marine Bryne Formation is overlain by shallow marine and coastal deposits of the Callovian Sandnes Formation (Fig. 34; Vollset \& Doré 1984). Similarly, the first fully marine Middle Jurassic deposits in the Danish Central Graben belong to the Callovian Lulu Formation, whereas the first comparable fully marine deposits in the Dutch Central Graben (referred to the Upper Graben Formation) are of Middle-Late Oxfordian age (see Herngreen et al. 2003, this volume). Thus the relatively sparse biostratigraphic data indicate a southwards younging of the transgression. The basal part of the Norwegian Haugesund and the Danish Lola Formations are of latest Callovian - Early Oxfordian age (Vollset \& Doré 1984; Jensen et al. 1986; Andsbjerg \& Dybkjær 2003, this volume). The onset of marine middle to outer shelf conditions thus started in latest Middle Jurassic time in the Central North Sea Basin, but only reached the southern part of the basin in the Oxfordian (Fig. 34; Herngreen \& Wong 1989).

\section{Late Jurassic marine deepening}

The structural reorganisation established during early Middle Jurassic uplift and subsequent erosion created the framework for the basin configuration that prevailed from the Middle and Late Jurassic into Early Cretaceous times. The Ringkøbing-Fyn High including adjacent areas to the south and north remained an uplifted landmass, forming the southern border of the 
Danish Basin. The landmass was submerged late in the Early Cretaceous. The Fennoscandian Border Zone and the easternmost part of the basin acted as a broad transition zone characterised by shallow marine to paralic or non-marine deposition during repeated transgressive-regressive cycles. These environmental conditions lasted into the earliest Early Cretaceous, when they were succeeded by deeper marine conditions.

The initial shallow marine conditions represented by the uppermost, probably Callovian part of the Haldager Sand Formation were succeeded by transgressive, paralic to marine deposition (Flyvbjerg Formation) in the Oxfordian. Dinoflagellate cysts from the lowermost part of the Flyvbjerg Formation in wells located in the Sorgenfrei-Tornquist Zone and in a well in the central part of the Danish Basin suggest an Early-Middle Oxfordian age and a marine origin for the basal part of the formation (Poulsen 1992, 1996). The transition from the shallow marine, regressive deposits of the uppermost part of the Flyvbjerg Formation to the transgressive, deeper marine deposits of the Børglum Formation seems to be of earliest Kimmeridgian age in the Danish Basin and of Late Kimmeridgian age in the Fennoscandian Border Zone, thus demonstrating a north-eastwards younging (Poulsen 1992, 1996) and recording the gradual transgression of the basin margin. The deepening represented by the Børglum Formation lasted from the earliest Kimmeridgian to the Middle Volgian in the Danish Basin. A regressive development followed with deposition of coarser sediments in most of the basin. In the Fennoscandian Border Zone, two-three coarsening-upwards successions with shallow marine silt and sand beds alternating with transgressive clays were deposited during the Volgian-Ryazanian (Frederikshavn Formation; Figs 30-32). Farther to the north-west, in the Norwegian- Danish Basin, a nearly time-equivalent succession of sedimentary rocks is referred, in stratigraphic order, to the Egersund, Tau and Sauda Formations (Vollset \& Doré 1984).

To the south-east, in Skåne, the lacustrine and lagoonal variegated claystones and siltstones of the Fyledal Clay were deposited during the Oxfordian and early Kimmeridgian, succeeded by prograding coastal plain deposits of the Nytorp Sand (Norling et al. 1993; Ahlberg et al. 2003, this volume). The Jurassic-Cretaceous transitional beds of the Vitabäck Clays are again dominated by brackish to freshwater deposits showing some marine influence.

The connection between the Central European basins and the Danish Basin along the Fennoscandian Border Zone was characterised by increased marine influence
(Fortuna Marl) during the Callovian (Fig. 34). During Late Jurassic time, marine communication between the Danish Basin and the North German Basin was mainly through the Central Graben, but a connection was periodically established through the Sorgenfrei-Tornquist Zone (Christensen \& Kilenyi 1970). The environment changed to mainly brackish water, while open marine conditions dominated in the Danish Basin. However, repeated regressive-transgressive events are recorded in Skåne and in northernmost Jylland. Precise stratigraphic correlation between these two areas is not yet possible due to scarce biostratigraphic data. CallovianKimmeridgian deposits are absent on Bornholm and in the Rønne Graben. The ?Volgian- Valanginian Rabekke, Robbedale and Jydegård Formations (Fig. 2), preserved east of the Rønne Graben, show a broadly transgressive development, probably reflecting the overall Early Cretaceous transgression in Northwest Europe.

\section{Late Jurassic graben development and sedimentation}

Onset of the main rifting following the Middle Jurassic uplift of the central North Sea Basin led to rapid subsidence of the Central Graben. Fault activity along the Coffee Soil Fault continued from Middle Jurassic through Late Jurassic times. The Central Graben was developed as a major half-graben, which became compartmentalised into a number of minor grabens and highs during the Late Jurassic (Møller 1986; Japsen et al. 2003, this volume; Møller \& Rasmussen 2003, this volume). Up to $4000 \mathrm{~m}$ of clay-dominated sediments were deposited in the Tail End Graben to the east during the Late Jurassic (Møller 1986; Michelsen et al. 1992).

The marine middle-outer shelf conditions which were established in latest Callovian time in the Danish Central Graben continued during the Late Jurassic overall sea-level rise. The Central Graben region was probably connected with the Danish Basin during most of the Late Jurassic through the north-western part of the Norwegian-Danish Basin, north of the Ringkøbing-Fyn High. The sedimentary facies of the Central Graben differ markedly from those of the Norwegian-Danish Basin, and none of the formations known from the Danish Basin can be traced to the Central Graben. These differences probably resulted from varying distances to the source areas and from differences in structural evolution.

Deposition of offshore muds of the Lola Formation in the eastern part of the Central Graben continued 


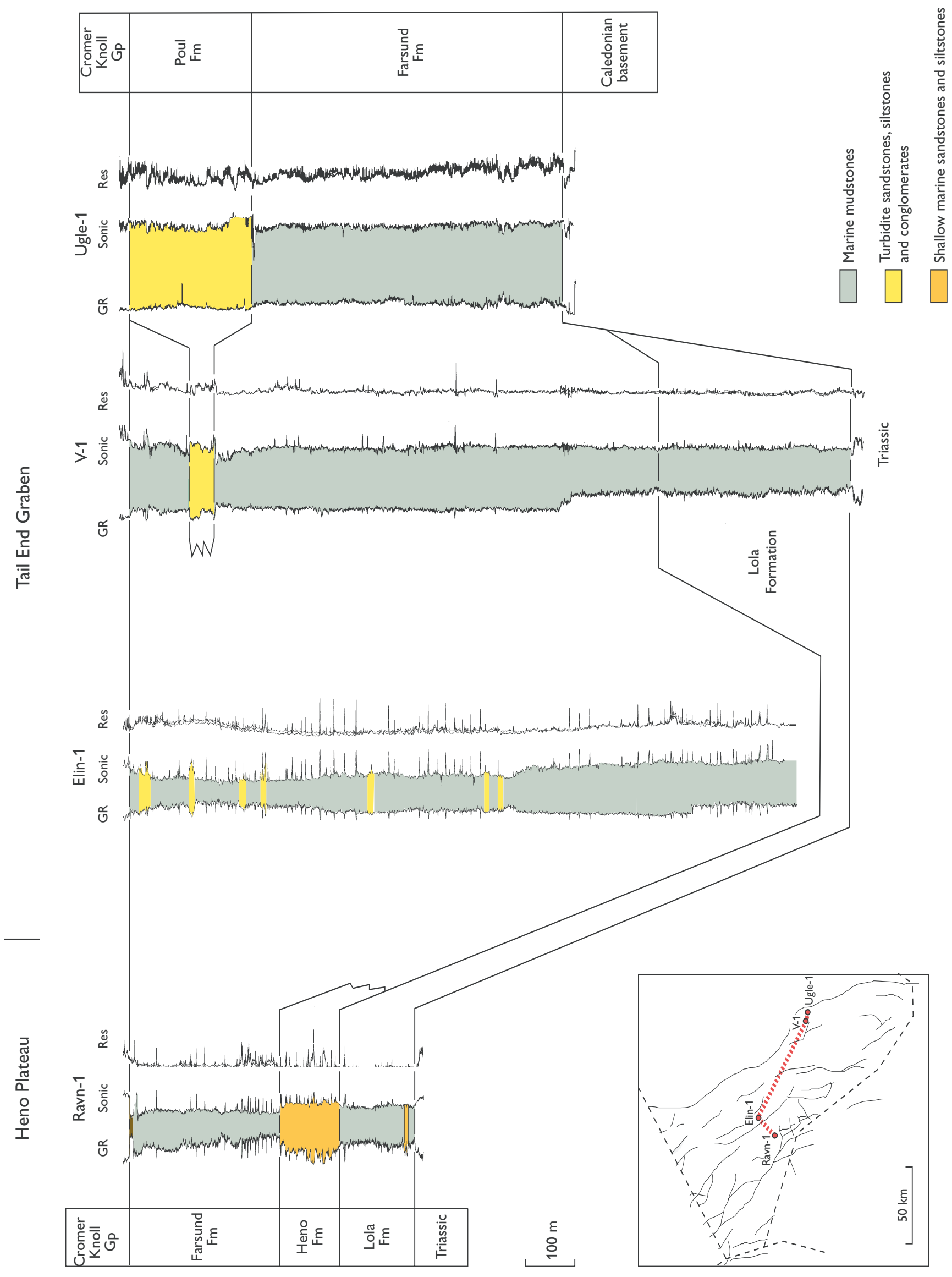


from the latest Callovian, and onlapped westwards onto the Heno Plateau during the Oxfordian-Kimmeridgian (Fig. 35; Michelsen et al. 1992; Johannessen \& Andsbjerg 1993; Andsbjerg \& Dybkjær 2003, this volume). Thin shallow marine sands were deposited at the western margin of the basin during deposition of the Lola Formation. This indicates that the sea transgressed westwards and up-dip from the eastern part of the Danish Central Graben. Deposition of offshore muds of the Lola Formation on the Heno Plateau was succeeded by shoreface sands of the Heno Formation during the latest Early - Late Kimmeridgian (Figs 35, 37; Andsbjerg \& Dybkjær 2003, this volume; Johannessen 2003, this volume). Shallow marine and back-barrier sediments of the Heno Formation were also deposited on the Gertrud Plateau and in the southern Feda Graben. Rapid subsidence of the individual basins of the Central Graben took place during latest Kimmeridgian time with an increased rate in the Early Volgian. Deposition of offshore muds dominated the entire graben area during latest Kimmeridgian - Volgian times, periodically with a significant increase in the content of organic matter as seen in the lower part of the Farsund Formation in the Feda Graben and Heno Plateau (Fig. 35; Damtoft et al. 1992). Locally, coarse-grained sediments deposited from sediment gravity flows (Poul Formation) interfinger with the claystones of the Farsund Formation adjacent to active fault zones (Fig. 37). The subsidence rates seem to have decreased in the latter part of the Volgian, and during the Late Volgian - Early Ryazanian, the highly radioactive Bo Member developed as a part of the Farsund Formation. Deposition of the organic-rich muds was governed by stratification of the water column, poor circulation, sea-level changes and reduced sediment influx (Ineson et al. 2003, this volume).

The Norwegian sector of the Central Graben developed in a similar way to that described for the Danish part. The Callovian - Early Volgian clay deposits are in-

\section{Facing page:}

Fig. 37. West-east well-log panel from the Danish Central Graben showing Middle/Upper Jurassic - Lower Cretaceous lithostratigraphic units with generalised depositional environments indicated by colour. Note the thin development of organic-rich mudstones (Bo Member) in the uppermost Farsund Formation of the Ravn-1 well; this member is not recognised in the V-1 and Ugle-1 wells close to the eastern flank of the Central Graben and is thick but only weakly developed in the Elin-1 well (see Ineson et al. 2003, this volume). cluded in the Haugesund Formation (Fig. 34), which differs from the partly time-equivalent Lola Formation in containing a number of thin sandstone beds and by forming an overall coarsening-upwards cycle (Vollset \& Doré 1984; see discussion in Forsberg et al. 1993). The overlying Farsund Formation is widely distributed north of the Danish sector. In the western part of the graben, a sand-dominated turbidite succession of Kimmeridgian age (Eldfisk Formation) forms a wedge between the Haugesund and Farsund Formations. In the Norwegian sector, the Farsund Formation is also capped by an organic-rich mudstone, named the Mandal Formation (Fig. 34).

To the south, in the Dutch sector, the Callovian Upper Oxfordian Lower, Middle and Upper Graben Formations (terrestrial-paralic) of the Dutch North Sea area are succeeded, with some overlap, by the Upper Oxfordian - Kimmeridgian Puzzle Hole Formation (lower delta plain deposits), indicating a northwards shift of the coastline during the Middle Oxfordian (Fig. 34; NAM \& RGD 1980; Herngreen \& Wong 1989; van Adrichem Boogaert \& Kouwe 1994; Herngreen et al. 2003 , this volume). Transgression was again initiated in the Late Oxfordian, as indicated by the southwards onlap by the deeper marine Kimmeridge Clay Formation (equivalent to the Lola and Farsund Formations) onto the shallow marine deposits. To the south, a barrier sand complex (the Volgian-Ryazanian Scruff Greensand Formation) seems to have been partly reworked into transgressive sheet sands overstepping the graben margins (Herngreen \& Wong 1989). At the JurassicCretaceous transition, anoxic conditions (Clay Deep Member) prevailed in the northern part of the Dutch North Sea area.

\section{Acknowledgements}

The referees G.F. Waldemar Herngreen and Gunver K. Pedersen and the editor Jon R. Ineson are thanked for many valuable suggestions. F.S. acknowledges the support of the Danish Natural Science Research Foundation; L.H.N. and F.S. acknowledge the use of Gravgærde, the field station of the University of Copenhagen on the island of Bornholm. 


\section{References}

Ahlberg, A., Sivhed, U. \& Erlström, M. 2003: The Jurassic of Skåne, southern Sweden. In: Ineson, J.R. \& Surlyk, F. (eds): The Jurassic of Denmark and Greenland. Geological Survey of Denmark and Greenland Bulletin 1, 527-541 (this volume).

Andsbjerg, J. 1997: Sedimentology and sequence stratigraphy of Middle Jurassic deposits. Danish and Norwegian Central Graben, 172 pp. Unpublished Ph.D. thesis, University of Copenhagen, Denmark.

Andsbjerg, J. 2003: Sedimentology and sequence stratigraphy of the Bryne and Lulu Formations, Middle Jurassic, northern Danish Central Graben. In: Ineson, J.R. \& Surlyk, F. (eds): The Jurassic of Denmark and Greenland. Geological Survey of Denmark and Greenland Bulletin 1, 301-347 (this volume).

Andsbjerg, J. \& Dybkjær, K. 2003: Sequence stratigraphy of the Jurassic of the Danish Central Graben. In: Ineson, J.R. \& Surlyk, F. (eds): The Jurassic of Denmark and Greenland. Geological Survey of Denmark and Greenland Bulletin 1, 265-300 (this volume).

Andsbjerg, J., Nielsen, L.H., Johannessen, P.N. \& Dybkjær, K. 2001: Divergent development of two neighbouring basins following the Jurassic North Sea doming event: the Danish Central Graben and the Norwegian-Danish Basin. In: Martinsen, O.J. \& Dreyer, T. (eds): Sedimentary environments offshore Norway - Palaeozoic to Recent. Norwegian Petroleum Society (NPF) Special Publication 10, 175-197.

Baartman, J.C. \& Christensen, O.B. 1975: Contributions to the interpretation of the Fennoscandian Border Zone. Danmarks Geologiske Undersøgelse II. Række 102, 47 pp.

Bartholin, C.T. 1892: Nogle i den bornholmske Jura formation forekommende planteforsteninger. Botanisk Tidsskrift 18, 12-28.

Bartholin, C.T. 1894: Nogle i den bornholmske Jura formation forekommende planteforsteninger. Botanisk Tidsskrift 19, 87-115.

Batten, D.J., Koppelhus, E.B. \& Nielsen, L.H. 1994: Uppermost Triassic to Middle Jurassic palynofacies and palynomiscellanea in the Danish Basin and Fennoscandian Border Zone. Cahiers de Micropaléontologie 9, 21-45.

Bergan, M., Tørudbakken, B. \& Wandås, B. 1989: Lithostratigraphic correlation of Upper Jurassic sandstones within the Norwegian Central Graben: sedimentological and tectonic implications. In: Collinson, J.D. (ed.): Correlation in hydrocarbon exploration, 243-251. London: Graham \& Trotman for the Norwegian Petroleum Society (NPF).

Bertelsen, F. 1978: The Upper Triassic - Lower Jurassic Vinding and Gassum Formations of the Norwegian-Danish Basin. Danmarks Geologiske Undersøgelse Serie B 3, 26 pp.

Bertelsen, F. 1980: Lithostratigraphy and depositional history of the Danish Triassic. Danmarks Geologiske Undersøgelse Serie B 4, 59 pp.

Birkelund, T. \& Pedersen, G.K. 1980: Middle Volgian ammonites and trace fossils from the Frederikshavn Member of the Bream Formation, northern Jutland. Danmarks Geologiske Undersøgelse Årbog 1979, 95-104.

Birkelund, T., Clausen, C.K., Hansen, H.N. \& Holm, L. 1983: The
Hectoroceras kochi zone (Ryazanian) in the North Sea Central Graben and remarks on the Late Cimmerian Unconformity. Danmarks Geologiske Undersøgelse Årbog 1982, 53-73.

Christensen, O.B. \& Kilenyi, T.I. 1970: Ostracod biostratigraphy of the Kimmeridgian in northern and western Europe. Danmarks Geologiske Undersøgelse II. Række 95, 65 pp.

Damtoft, K., Nielsen, L.H., Johannessen, P.N., Thomsen, E. \& Andersen, P.R. 1992: Hydrocarbon plays of the Danish Central Trough. In: Spencer, A.M. (ed.): Generation, accumulation and production of Europe's hydrocarbons II. European Association of Petroleum Geoscientists Special Publication 2, $35-58$.

Donovan, D.T. \& Surlyk, F. 2003: Lower Jurassic (Pliensbachian) ammonites from Bornholm, Baltic Sea, Denmark. In: Ineson, J.R. \& Surlyk, F. (eds): The Jurassic of Denmark and Greenland. Geological Survey of Denmark and Greenland Bulletin 1, 555-583 (this volume).

Dybkjær, K. 1988: Palynological zonation and stratigraphy of the Jurassic section in the Gassum No. 1-borehole, Denmark. Danmarks Geologiske Undersøgelse Serie A 21, 72 pp.

Dybkjær, K. 1991: Palynological zonation and palynofacies investigation of the Fjerritslev Formation (Lower Jurassic - basal Middle Jurassic) in the Danish Subbasin. Danmarks Geologiske Undersøgelse Serie A 30, 150 pp.

Dybkjær, K. 1998: Palynological dating of the Mandal Formation (uppermost Jurassic - lowermost Cretaceous, Norwegian Central Graben) and correlation to organic-rich shales in the Danish sector. Marine and Petroleum Geology 15, 495-503.

Erlström, M., Sivhed, U. \& Surlyk, F. 1999: A backstepping fluviatile-paralic-marine succession, Sinemurian, Lower Jurassic, Skåne, southern Sweden. Bulletin of the Geological Society of Denmark 46, 1-12.

EUGENO-S Working Group 1988: Crustal structure and tectonic evolution of the transition between the Baltic Shield and the North German Caledonides (the EUGENO-S Project). Tectonophysics 150, 253-348.

Forchhammer, J.G. 1837: Om de bornholmske Kulformationer. Det Kongelige Danske Videnskabernes Selskabs Skrifter. Naturvidenskabelig og Matematisk Afdeling 7, 64 pp.

Forsberg, A., Gowers, M.B. \& Holtar, E. 1993: Multi-disciplinary stratigraphic analysis of the Upper Jurassic strata of the Norwegian Central Trough. In: Spencer, A.M. (ed.): Generation, accumulation and production of Europe's hydrocarbons III. European Association of Petroleum Geoscientists Special Publication 3, 45-58.

Frandsen, N. \& Surlyk, F. 2003: An offshore transgressive-regressive mudstone-dominated succession from the Sinemurian of Skåne, Sweden. In: Ineson, J.R. \& Surlyk, F. (eds): The Jurassic of Denmark and Greenland. Geological Survey of Denmark and Greenland Bulletin 1, 543-554 (this volume).

Gowers, M.B. \& Sæbøe, A. 1985: On the structural evolution of the Central Trough in the Norwegian and Danish sectors of the North Sea. Marine and Petroleum Geology 2, 298-318.

Gravesen, P., Rolle, F. \& Surlyk, F. 1982: Lithostratigraphy and sedimentary evolution of the Triassic, Jurassic and Lower Cretaceous of Bornholm, Denmark. Danmarks Geologiske Undersøgelse Serie B 7, 51 pp. 
Gregersen, A. \& Sorgenfrei, T. 1951: Efterforskningsarbejdet i Danmarks dybere undergrund. Meddelelser fra Dansk Geologisk Forening 12(1), 141-151.

Grönwall, K.A. 1899: Bemærkninger om Bornholms sedimentære Dannelser og deres tektoniske Forhold. Danmarks Geologiske Undersøgelse II. Række 10, 1-48.

Gry, H. 1969: Megaspores from the Jurassic of the island of Bornholm, Denmark. Meddelelser fra Dansk Geologisk Forening 19, 69-89.

Hamann, N.-E. 1994: Den tektoniske udvikling af Rønne Graven - et seismisk studie, 136 pp. Unpublished Ph.D. thesis, University of Copenhagen, Denmark.

Hamberg, L. 1994: Anatomy of clastic coastal sequences in the Rhaetian Gassum Formation, Stenlille, Denmark, 90 pp. Unpublished Ph.D. thesis, University of Copenhagen, Denmark.

Hamberg, L. \& Nielsen, L.H. 2000: Shingled, sharp-based shoreface sandstones and the importance of stepwise forced regression in a shallow basin, Upper Triassic Gassum Formation, Denmark. In: Hunt, D. \& Gawthorpe, R.L. (eds): Sedimentary responses to forced regressions. Geological Society Special Publication (London) 172, 69-89.

Heilmann-Clausen, C. 1987: Lower Cretaceous dinoflagellate biostratigraphy in the Danish Central Trough. Danmarks Geologiske Undersøgelse Serie A 17, 89 pp.

Herngreen, G.F.W. \& Wong, T.E. 1989: Revision of the 'Late Jurassic' stratigraphy of the Dutch Central North Sea Graben. Geologie en Mijnbouw 68, 73-105.

Herngreen, G.F.W., Kouwe, W.F.P. \& Wong, T.E. 2003: The Jurassic of the Netherlands. In: Ineson, J.R. \& Surlyk, F. (eds): The Jurassic of Denmark and Greenland. Geological Survey of Denmark and Greenland Bulletin 1, 217-229 (this volume).

Hjort, A. 1899: Om Vellensbyleret og dets Flora. Danmarks Geologiske Undersøgelse II. Række 10, 61-86.

Hoelstad, T. 1985: Palynology of the uppermost Lower to Middle Jurassic strata on Bornholm, Denmark. Bulletin of the Geological Society of Denmark 34, 111-132.

Hoelstad, T. 1986a: Palynology of the Middle Jurassic Lower Graben Sand Formation of the U-1 well, Danish Central Trough. Danmarks Geologiske Undersøgelse Serie A 14, 25 pp.

Hoelstad, T. 1986b: Palynology and palynofacies analysis of the Middle Jurassic to Lower Cretaceous in the Danish Central Trough. DGU internal report 43, 25 pp. Copenhagen: Geological Survey of Denmark.

Höhne, R. 1933: Beiträge zur Stratigraphie, Tektonik und Paläogeographie des südbaltischen Rhät-Lias, insbesondere auf Bornholm. Abhandlungen aus dem geologisch-palaeontologischen Institut Greifswald Heft 12, 31-70.

Ineson, J.R., Bojesen-Koefoed, J.A., Dybkjær, K. \& Nielsen, L.H. 2003: Volgian-Ryazanian 'hot shales' of the Bo Member (Farsund Formation) in the Danish Central Graben, North Sea: stratigraphy, facies and geochemistry. In: Ineson, J.R. \& Surlyk, F. (eds): The Jurassic of Denmark and Greenland. Geological Survey of Denmark and Greenland Bulletin 1, 403-436 (this volume).

Japsen, P., Britze, P. \& Andersen, C. 2003: Upper Jurassic - Lower Cretaceous of the Danish Central Graben: structural framework and nomenclature. In: Ineson, J.R. \& Surlyk, F. (eds): The
Jurassic of Denmark and Greenland. Geological Survey of Denmark and Greenland Bulletin 1, 233-246 (this volume).

Jensen, J.B. \& Hamann, N.E. 1989: Geological mapping of Mesozoic deposits along the eastern margin of the Rønne Graben, offshore Bornholm, Denmark. Bulletin of the Geological Society of Denmark 37, 237-260.

Jensen, T.F., Holm, L., Frandsen, N. \& Michelsen, O. 1986: Jurassic - Lower Cretaceous lithostratigraphic nomenclature for the Danish Central Trough. Danmarks Geologiske Undersøgelse Serie A 12, 65 pp.

Jespersen, M. 1866: En skitse af Sorthats Kulværk på Bornholm. Indbydelsesskrift til de offentlige Examina i Rønne Højere Realskole, 5-38.

Jespersen, M. 1869: Bidrag til Bornholms geoteknik. II. De geotekniske forhold i Knudskerplateauets omegn. Naturhistorisk Tidsskrift 3. Række 6, 1-48.

Johannessen, P.N. 1995: Genetic stratigraphy of shallow marine and paralic deposits: Upper Jurassic, Danish Central Graben; Upper Cretaceous, San Juan Basin, New Mexico; and Lower Jurassic, Bornholm, Baltic Sea 1-4, 107 pp. (parts paginated separately). Unpublished Ph.D. thesis, University of Copenhagen, Denmark.

Johannessen, P.N. 1997: Upper Jurassic, back-barrier and shoreface reservoir sandstones and thin turbidite sandstones in the Danish Central Trough, North Sea. In: Oakman, C.D., Martin, J.H. \& Corbett, P.W.M. (eds): Cores from the Northwest European hydrocarbon province: an illustration of geological applications from exploration to development, 11-22. London: Geological Society.

Johannessen, P.N. 2003: Sedimentology and sequence stratigraphy of paralic and shallow marine Upper Jurassic sandstones in the northern Danish Central Graben. In: Ineson, J.R. \& Surlyk, F. (eds): The Jurassic of Denmark and Greenland. Geological Survey of Denmark and Greenland Bulletin 1, 367-402 (this volume).

Johannessen, P.N. \& Andsbjerg, J. 1993: Middle to Late Jurassic basin evolution and sandstone reservoir distribution in the Danish Central Trough. In: Parker, J.R. (ed.): Petroleum geology of Northwest Europe: proceedings of the 4th conference, 271-283. London: Geological Society.

Johannessen, P.N., Dybkjær, K. \& Rasmussen, E.S. 1996: Sequence stratigraphy of Upper Jurassic reservoir sandstones in the northern part of the Danish Central Trough, North Sea. Marine and Petroleum Geology 13, 755-770.

Klingspor, I. 1976: Radiometric age-determinations of basalts, dolerites and related syenite in Skåne, southern Sweden. Geologiska Föreningens i Stockholm Förhandlingar 98, 195-216.

Koch, J.-O. 1983: Sedimentology of Middle and Upper Jurassic sandstone reservoirs of Denmark. Geologie en Mijnbouw 62 , 115-129.

Koch, J.-O., Holm, L. \& Michelsen, O. 1982: Jurassic. In: Michelsen, O. (ed.): Geology of the Danish Central Graben. Danmarks Geologiske Undersøgelse Serie B 8, 37-45.

Koppelhus, E.B. 1988: Catalogue of spores and pollen from the Lower-Middle Jurassic Bagå Formation on Bornholm, Denmark. DGU confidential report 21, 42 pp. Copenhagen: Geological 
Survey of Denmark.

Koppelhus, E.B. 1991: Palynology of the Lower Jurassic Rønne Formation on Bornholm, eastern Denmark. Bulletin of the Geological Society of Denmark 39, 91-109.

Koppelhus, E.B. \& Batten, D.J. 1992: Megaspore assemblages from the Jurassic and lowermost Cretaceous of Bornholm, Denmark. Danmarks Geologiske Undersøgelse Serie A 32, $81 \mathrm{pp}$.

Koppelhus, E.B. \& Nielsen, L.H. 1994: Palynostratigraphy and palaeoenvironments of the Lower to Middle Jurassic Bagå Formation of Bornholm, Denmark. Palynology 18, 139-194.

Larsen, G. 1966: Rhaetic - Jurassic - Lower Cretaceous sediments in the Danish Embayment (a heavy-mineral study). Danmarks Geologiske Undersøgelse II. Række 91, 127 pp.

Larsen, G., Christensen, O.B., Bang, I. \& Buch, A. 1968: Øresund. Helsingør-Hälsingborg Linien. Geologisk rapport. Danmarks Geologiske Undersøgelse Rapport 1, 90 pp. + table volume (summary in English).

Liboriussen, J., Ashton, P. \& Tygesen, T. 1987: The tectonic evolution of the Fennoscandian Border Zone in Denmark. In: Ziegler, P.A. (ed.): Compressional intra-plate deformations in the Alpine Foreland. Tectonophysics 137, 21-29.

Mackertich, D. 1996: The Fife Field, UK Central North Sea. Petroleum Geoscience 2, 373-380.

Malling, C. 1911: Hasle-Sandstenens alder. Meddelelser fra Dansk Geologisk Forening 3, 629-631.

Malling, C. 1914: De Jespersenske Buelag i Lias paa Bornholm. Meddelelser fra Dansk Geologisk Forening 4, 265-270.

Malling, C. 1920: Den marine Lias og Wealden-Aflejringer paa Bornholm. Meddelelser fra Dansk Geologisk Forening 5 55-57.

Malling, C. \& Grönwall, K.A. 1909: En Fauna i Bornholms Lias. Meddelelser fra Dansk Geologisk Forening 3, 271-316.

Meinhold, R., Unger, E. \& Wienholz, R. 1960: Neue Erkenntnisse über den prätertiären Untergrund des Flachlandgebietes der Deutschen Demokratischen Republik. International Geological Congress, 21st session, Norden 11, 87-100.

Michelsen, O. 1975: Lower Jurassic biostratigraphy and ostracods of the Danish Embayment. Danmarks Geologiske Undersøgelse II. Række 104, 287 pp.

Michelsen, O. 1978a: Stratigraphy and distribution of Jurassic deposits of the Norwegian-Danish Basin. Danmarks Geologiske Undersøgelse Serie B 2, 28 pp.

Michelsen, O. 1978b: The Lower Jurassic of the Dansk Nords $\varnothing$ O-1 boring, Central Trough. Danmarks Geologiske Undersøgelse Årbog 1977, 77-89.

Michelsen, O. 1989a: Revision of the Jurassic lithostratigraphy of the Danish Subbasin. Danmarks Geologiske Undersøgelse Serie A 24, 21 pp.

Michelsen, O. 1989b: Log-sequence analysis and environmental aspects of the Lower Jurassic Fjerritslev Formation in the Danish Subbasin. Danmarks Geologiske Undersøgelse Serie A 25, 23 pp.

Michelsen, O. \& Nielsen, L.H. 1991: Well records on the Phanerozoic stratigraphy in the Fennoscandian Border Zone, Denmark. Hans-1, Sæby-1, and Terne-1 wells. Danmarks Geologiske Undersøgelse Serie A 29, 37 pp.
Michelsen, O. \& Nielsen, L.H. 1993: Structural development of the Fennoscandian Border Zone, offshore Denmark. Marine and Petroleum Geology 10, 124-134.

Michelsen, O. \& Wong, T.E. 1991: Discussion of Jurassic lithostratigraphy in the Danish, Dutch and Norwegian Central Graben areas. In: Michelsen, O. \& Frandsen, N. (eds): The Jurassic in the southern Central Trough. Danmarks Geologiske Undersøgelse Serie B 16, 20-28.

Michelsen, O., Frandsen, N., Holm, L., Jensen, T.F., Møller, J.J. \& Vejbæk, O.V. 1987: Jurassic - Lower Cretaceous of the Danish Central Trough - depositional environments, tectonism, and reservoirs. Danmarks Geologiske Undersøgelse Serie A 16, $45 \mathrm{pp}$.

Michelsen, O., Mogensen, T.E. \& Korstgård, J.A. 1992: PreCretaceous structural development of the Danish Central Trough and its implications for the distribution of Jurassic sands. In: Larsen, R.M. et al. (eds): Structural and tectonic modelling and its application to petroleum geology. Norwegian Petroleum Society (NPF) Special Publication 1, 495-506.

Mogensen, T.E. 1994: Palaeozoic structural development along the Tornquist Zone, Kattegat area, Denmark. In: Cloetingh, S. et al. (eds): Dynamics of extensional basin formation and inversion. Tectonophysics 240, 191-214.

Mogensen, T.E. 1996: Triassic and Jurassic structural development along the Tornquist Zone, Kattegat, Denmark. Tectonophysics 252, 197-220.

Mogensen, T.E. \& Korstgård, J.A. 1993: Structural development and trap formation along the Børglum Fault, Tornquist Zone, Denmark, compared with the Painted Canyon Fault, San Andreas Zone, USA. In: Spencer, A.M. (ed.): Generation, accumulation and production of Europe's hydrocarbons III. European Association of Petroleum Geoscientists Special Publication 3, 89-97.

Mogensen, T.E. \& Korstgård, J.A. 2003: Triassic and Jurassic transtension along part of the Sorgenfrei-Tornquist Zone in the Danish Kattegat. In: Ineson, J.R. \& Surlyk, F. (eds): The Jurassic of Denmark and Greenland. Geological Survey of Denmark and Greenland Bulletin 1, 439-458 (this volume).

Møller, H. 1902: Bidrag till Bornholms Fossila Flora. Pteridofyter. Lunds Universitets Årsskrift 38 Afd. 2(5), 63 pp.

Møller, H. 1903: Bidrag till Bornholms Fossila Flora (Rhät och Lias). Gymnospermer. Kongeliga Svenska Vetenskabs-Akademiens Handlingar 36(6), 56 pp.

Møller, J.J. 1986: Seismic structural mapping of the Middle and Upper Jurassic in the Danish Central Trough. Danmarks Geologiske Undersøgelse Serie A 13, 37 pp.

Møller, J.J. \& Rasmussen, E.S. 2003: Middle Jurassic - Early Cretaceous rifting of the Danish Central Graben. In: Ineson, J.R. \& Surlyk, F. (eds): The Jurassic of Denmark and Greenland. Geological Survey of Denmark and Greenland Bulletin 1, 247-264 (this volume).

NAM \& RGD 1980: Stratigraphic nomenclature of the Netherlands. Verhandelingen van het Koninklijk Nederlands Geologisch en Mijnbouwkundig Genootschap 32, 77 pp. (Nederlandse Aardolie Maatschappij \& Rijks Geologische Dienst).

Nielsen, L.H. 1987: Progress report 1.1.1988. Biostratigraphy and organic geochemistry of the Mesozoic on Bornholm. DGU 
confidential report 31, 35 pp. Copenhagen: Geological Survey of Denmark.

Nielsen, L.H. 1992: Sedimentologi og sekvensstratigrafi af de øvre triassiske - nedre jurassiske aflejringer i det Danske Bassin og den Fennoskandiske Randzone. Dansk Geologisk Forenings Årsskrift 1990-1991, 143-154.

Nielsen, L.H. 1994: Øvre Trias - Mellem Jura aflejringerne i det Danske Bassin. Dansk Geologisk Forening 100 års jubiløeumssymposium - Geologi på tværs af det Danske Rige. Copenhagen, 19-20 November 1993. Abstracts, 35-38.

Nielsen, L.H. 1995: Genetic stratigraphy of the Upper Triassic Middle Jurassic deposits of the Danish Basin and Fennoscandian Border Zone 2, 3, 162 pp. Unpublished Ph.D. thesis, University of Copenhagen, Denmark.

Nielsen, L.H. 2003: Late Triassic - Jurassic development of the Danish Basin and the Fennoscandian Border Zone, southern Scandinavia. In: Ineson, J.R. \& Surlyk, F. (eds): The Jurassic of Denmark and Greenland. Geological Survey of Denmark and Greenland Bulletin 1, 459-526 (this volume).

Nielsen, L.H. \& Koppelhus, E.B. 1989: Results of the project: Biostratigraphy and organic geochemistry of the Mesozoic on Bornholm. Final report 1.7.1989. DGU confidential report 49, 49 pp. Copenhagen: Geological Survey of Denmark.

Nielsen, L.H. \& Japsen, P. 1991: Deep wells in Denmark 1935-1990. Danmarks Geologiske Undersøgelse Serie A 31, 177 pp.

Nielsen, L.H., Larsen, F. \& Frandsen, N. 1989: Upper Triassic Lower Jurassic tidal deposits of the Gassum Formation on Sjælland, Denmark. Danmarks Geologiske Unders $\varnothing$ gelse Serie A 23, $30 \mathrm{pp}$.

Norling, E. 1972: Jurassic stratigraphy and foraminifera of western Scania, southern Sweden. Sveriges Geologiska Undersökning Serie Ca 47, 120 pp.

Norling, E. \& Bergström, J. 1987: Mesozoic and Cenozoic tectonic evolution of Scania, southern Sweden. In: Ziegler, P.A. (ed.): Compressional intra-plate deformations in the Alpine Foreland. Tectonophysics 137, 7-19.

Norling, E., Ahlberg, A., Erlström, M. \& Sivhed, U. 1993: Guide to the Upper Triassic and Jurassic geology of Sweden. Sveriges Geologiska Undersökning Serie Ca 82, 71 pp.

Nørvang, A. 1946: Marine Lias in Jutland. Meddelelser fra Dansk Geologisk Forening 11, 139 pp.

Nørvang, A. 1957: The foraminifera of the Lias Series in Jutland, Denmark. Meddelelser fra Dansk Geologisk Forening 13, 275-414.

Pedersen, G.K. 1985: Thin, fine-grained storm layers in a muddy shelf sequence: an example from the Lower Jurassic in the Stenlille 1 well, Denmark. Journal of the Geological Society (London) 142, 357-374.

Pedersen, G.K. 1986: Changes in the bivalve assemblage of an Early Jurassic mudstone sequence (the Fjerritslev Formation in the Gassum 1 well, Denmark). Palaeogeography, Palaeoclimatology, Palaeoecology 53, 139-168.

Petersen, H.I. 1993: Petrographic facies analysis of Lower and Middle Jurassic coal seams on the island of Bornholm, Denmark. International Journal of Coal Geology 22, 189-216.

Petersen, H.I. 1994: Depositional environments of coals and associated siliciclastic sediments in the Lower and Middle Jurassic of Denmark. The Øresund-5, -7, -13, -15 and -18 wells. Danmarks Geologiske Undersøgelse Serie A 33, 55 pp.

Petersen, H.I. \& Andsbjerg, J. 1996: Organic facies development within Middle Jurassic coal seams, Danish Central Graben, and evidence for relative sea-level control on peat accumulation in a coastal plain environment. Sedimentary Geology 106, 259-277.

Petersen, H.I. \& Nielsen, L.H. 1995: Controls on peat accumulation and depositional environments of a coal-bearing coastal plain succession of a pull-apart basin; a petrographic, geochemical and sedimentological study, Lower Jurassic, Denmark. International Journal of Coal Geology 27, 99-129.

Petersen, H.I. \& Rosenberg, P. 1998: Reflectance retardation (suppression) and source rock properties related to hydrogenenriched vitrinite in Middle Jurassic coals, Danish North Sea. Journal of Petroleum Geology 21, 247-263.

Petersen, H.I., Rosenberg, P. \& Andsbjerg, J. 1996: Organic geochemistry in relation to the depositional environments of Middle Jurassic coal seams, Danish Central Graben, and implications for hydrocarbon generative potential. American Association of Petroleum Geologists Bulletin 80, 47-62.

Petersen, H.I., Andsbjerg, A., Bojesen-Koefoed, J., Nytoft, H.P. \& Rosenberg, P. 1998: Petroleum potential and depositional environments of Middle Jurassic coals and non-marine deposits, Danish Central Graben, with special reference to the Søgne Basin. Geology of Denmark Survey Bulletin 36, 78 pp.

Petersen, H.I., Andsbjerg, J., Bojesen-Koefoed, J.A. \& Nytoft, H.P. 2000: Coal-generated oil: source rock evaluation and petroleum geochemistry of the Lulita oilfield, Danish North Sea. Journal of Petroleum Geology 23, 55-90.

Petersen, H.I., Nielsen, L.H., Bidstrup, T. \& Thomsen, E. 2003: Burial depth and post-Early Cretaceous uplift of Lower-Middle Jurassic strata in the Fennoscandian Border Zone based on organic maturity. In: Ineson, J.R. \& Surlyk, F. (eds): The Jurassic of Denmark and Greenland. Geological Survey of Denmark and Greenland Bulletin 1, 611-630 (this volume).

Petersen, H.I., Nielsen, L.H., Koppelhus, E.B. \& Sørensen, H.S. 2003: Early and Middle Jurassic mires of Bornholm and the Fennoscandian Border Zone: a comparison of depositional environments and vegetation. In: Ineson, J.R. \& Surlyk, F. (eds): The Jurassic of Denmark and Greenland. Geological Survey of Denmark and Greenland Bulletin 1, 631-656 (this volume).

Poulsen, N.E. 1986: Callovian-Volgian dinocyst stratigraphy of the Central Trough in the Danish North Sea area. Bulletin of the Geological Society of Denmark 35, 1-10.

Poulsen, N.E. 1991: Upper Jurassic dinocyst stratigraphy in the Danish Central Trough. In: Michelsen, O. \& Frandsen, N. (eds) The Jurassic in the southern Central Trough. Danmarks Geologiske Undersøgelse Serie B 16, 7-15.

Poulsen, N.E. 1992: Jurassic dinoflagellate cyst biostratigraphy of the Danish Subbasin in relation to sequences in England and Poland; a preliminary review. Review of Palaeobotany and Palynology 75, 33-52.

Poulsen, N.E. 1994: Dinoflagellate cyst biostratigraphy of Rhaetian-Ryazanian (uppermost Triassic - lowermost Cretaceous) deposits from the Danish Subbasin. Geobios 17, 409-414. 
Poulsen, N.E. 1996: Dinoflagellate cysts from marine Jurassic deposits of Denmark and Poland. American Association of Stratigraphic Palynologists Contributions Series 31, 227 pp.

Rasmussen, L.B. 1974: Some geological results from the first five Danish exploration wells in the North Sea. Danmarks Geologiske Undersøgelse III. Række 42, 47 pp.

Rasmussen, L.B. 1978: Geological aspects of the Danish North Sea sector; with a report on the wells Dansk Nords $\varnothing$ E-1, E-2, F-1, G-1, H-1, I-1, J-1, and K-1. Danmarks Geologiske Undersøgelse III. Række 44, 85 pp.

Richards, P.C., Lott, G.K., Johnson, H., Knox, R.W.O'B. \& Riding, J.B. 1993: Jurassic of the Central and Northern North Sea. In: Knox, R.W.O'B. \& Cordey, W.G. (eds): Lithostratigraphic nomenclature of the UK North Sea 3, 219 pp. Nottingham: British Geological Survey.

Ro, H.E., Larsson, F.R., Kinck, J.J. \& Husebye, E.S. 1990: The Oslo Rift - its evolution on the basis of geological and geophysical observations. In: Neumann, E.-R. (ed.): Rift zones in the continental crust of Europe - geophysical, geological and geochemical evidence: Oslo-Horn Graben. Tectonophysics 178, $11-28$.

Rolle, F., Koch, J.-O., Frandsen, N. \& Surlyk, F. 1979: Jurassic environments in the Fenno-Scandian Border Zone. Symposium on 'Sédimentation jurassique W. européen'. Association Sedimentologie Francais Publication Spéciale 1, 15-31.

Sellwood, B.W. 1972: Tidal flat sedimentation in the Lower Jurassic of Bornholm, Denmark. Palaeogeography, Palaeoclimatology, Palaeoecology 11, 93-106.

Sivhed, U. 1984: Litho- and biostratigraphy of the Upper Triassic - Middle Jurassic in Scania, southern Sweden. Sveriges Geologiska Undersökning Serie C 806, 31 pp.

Söderström, B., Forsberg, A., Holtar, E. \& Rasmussen, B.A. 1991: The Mjølner Field, a deep Upper Jurassic oil field in the central North Sea. First Break 29, 156-171.

Sorgenfrei, T. 1969: Geological perspectives in the North Sea area. Meddelelser fra Dansk Geologisk Forening 19, 160-196.

Sorgenfrei, T. \& Buch, A. 1964: Deep tests in Denmark, 1935-1959. Danmarks Geologiske Undersøgelse III. Række 36, 146 pp.

Surlyk, F. \& Noe-Nygaard, N. 1986: Hummocky cross-stratification from the Lower Jurassic Hasle Formation of Bornholm, Denmark. Sedimentary Geology 46, 259-273.

Surlyk, F., Arndorff, L., Hamann, N.-E., Hamberg, L., Johannessen, P.N., Koppelhus, E.B., Nielsen, L.H., Noe-Nygaard, N., Pedersen, G.K. \& Petersen, H.I. 1995: High-resolution sequence stratigraphy of a Hettangian-Sinemurian paralic succession, Born- holm, Denmark. Sedimentology 42, 323-354.

Thomsen, E., Damtoft, K. \& Andersen, C. 1987: Hydrocarbon plays in Denmark outside the Central Trough. In: Brooks, J. \& Glennie, K.W. (eds): Petroleum geology of North West Europe, 375-388. London: Graham \& Trotman.

Troedsson, G. 1951: On the Höganäs Series of Sweden (RhaetoLias). Lunds Universitet Årsskrift Ny Följd 2 47(1), 269 pp.

Tyge, P. 1990: Palaeotidale processer i en mundingsbarre association fra den Nedre Jurassiske Galgeløkke Member, Bornholm. Dansk Geologisk Forenings Årsskrift 1987-1989, 37-40.

Underhill, J.R. \& Partington, M.A. 1993: Jurassic thermal doming and deflation in the North Sea: implications of the sequence stratigraphic evidence. In: Parker, J.R. (ed.): Petroleum geology of Northwest Europe: proceedings of the 4th conference, 337-345. London: Geological Society.

Underhill, J.R. \& Partington, M.A. 1994: Use of genetic sequence stratigraphy in defining and determining a regional tectonic control on the 'Mid-Cimmerian Unconformity' - implications for North Sea basin development and the global sea-level chart. In: Weimer, P. \& Posamentier, H.W. (eds): Siliciclastic sequence stratigraphy: recent developments and applications. American Association of Petroleum Geologists Memoir 58, 449-484

van Adrichem Boogaert, H.A. \& Kouwe, W.F.P. (compilers) 1994: Stratigraphic nomenclature of the Netherlands, revision and update by RGD and NOGEPA. Mededelingen Rijks Geologische Dienst 50, sections A-J (sections paginated independently).

Vejbæk, O.V. 1989: Effects of asthenospheric heat flow in basin modelling exemplified with the Danish Basin. Earth and Planetary Science Letters 95, 97-114.

Vejbæk, O.V. 1992: Geodynamic modelling of the Danish Central Trough. In: Larsen, R.M. et al. (eds): Structural and tectonic modelling and its application to petroleum geology. Norwegian Petroleum Society (NPF) Special Publication 1, 1-17.

Vejbæk, O.V. 1997: Dybe strukturer i danske sedimentære bassiner. Geologisk Tidsskrift 4, 1-31.

Vollset, J. \& Doré, A.G. (eds) 1984: A revised Triassic and Jurassic lithostratigraphic nomenclature for the Norwegian North Sea. Norwegian Petroleum Directorate Bulletin 3, 53 pp.

Ziegler, P.A. 1975: Geologic evolution of the North Sea and its tectonic framework. American Association of Petroleum Geologists Bulletin 59, 1073-1097.

Ziegler, P.A. 1990: Geological atlas of western and central Europe, 2nd edition, 239 pp. Amsterdam: Elsevier for Shell Internationale Petroleum Maatschappij. 